Research Report

No 269

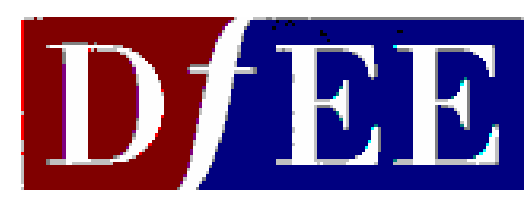

\title{
Learning and Training at Work 2000
}

\author{
David Spilsbury \\ IFF Research Ltd
}

The views expressed in this report are the authors' and do not necessarily reflect those of the Department for Education and Employment.

(c) Crown Copyright 2001. Published with the permission of DfEE on behalf of the Controller of Her Majesty's Stationery Office. Applications for reproduction should be made in writing to The Crown Copyright Unit, Her Majesty's Stationery Office, St Clements House, 2-16 Colegate, Norwich NR3 1BQ.

ISBN 1841855049

April 2001 


\section{Table Of Contents}

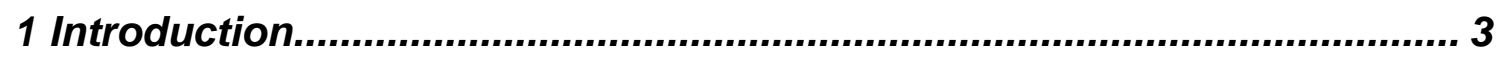

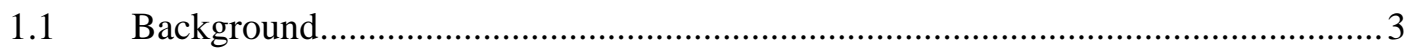

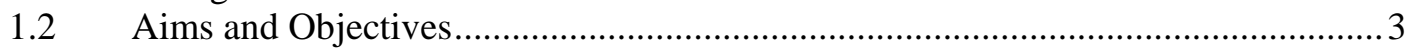

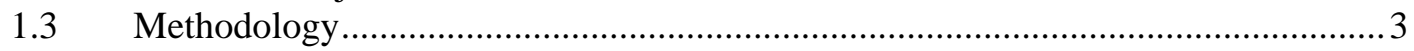

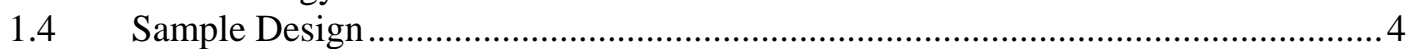

1.5 Comparison with Skill Needs in Britain Surveys .................................................. 4

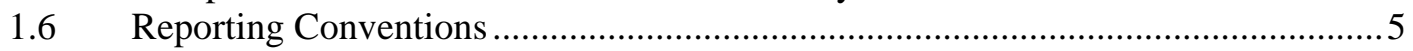

2 Summary of Findings........................................................................ 9

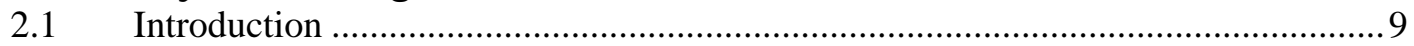

A) Learning and Training at Work 1999 and 2000 Surveys ...................................... 10

$2.2 \quad$ Skill Needs and Recruitment Difficulties ................................................................. 10

2.3 Learning Opportunities and Facilities Available for Employees...............................10

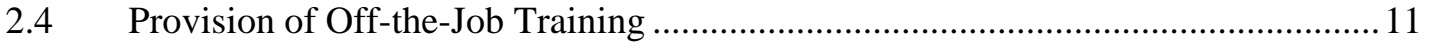

$2.5 \quad$ Management of Training and Training Delivery ....................................................... 11

2.6 Provision of On-the-Job Training .......................................................................... 12

2.7 Provision of Training and Reasons for Non-Provision.......................................... 12

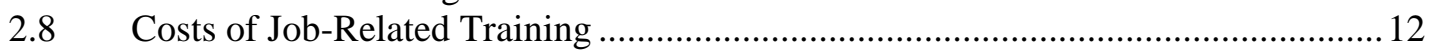

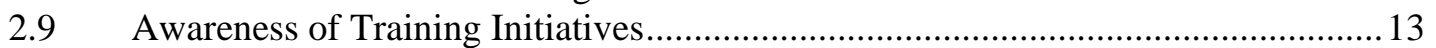

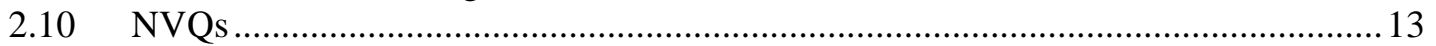

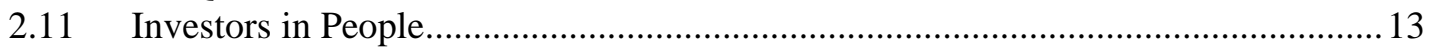

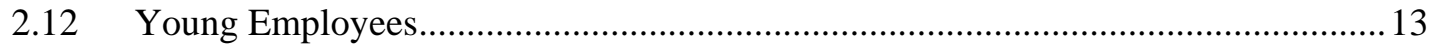

B) Comparison with SNIB 97 and 98 and Learning and Training at Work 1999

Surveys (ref. section 12) ..................................................................................... 14

2.13 Skill Needs and Recruitment Difficulties .................................................................. 14

2.14 Learning Opportunities and Facilities Available for Employees...............................14

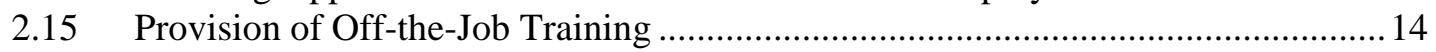

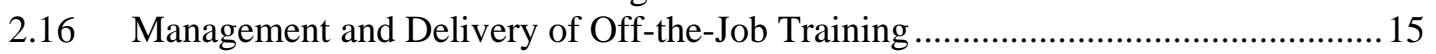

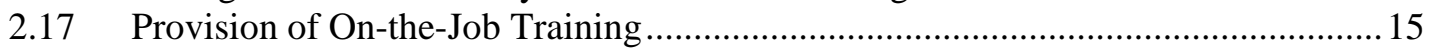

2.18 Awareness of, and Involvement with, Training Initiatives....................................15

3 Skill Needs and Recruitment Difficulties................................................ 19

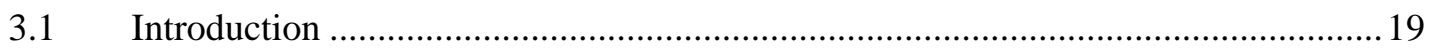

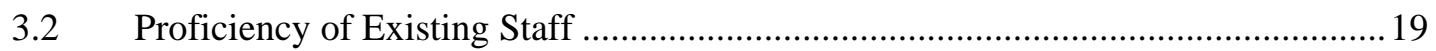

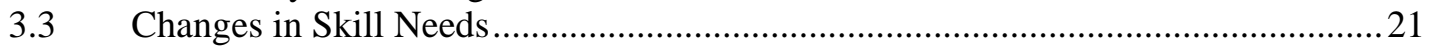

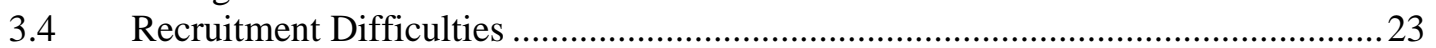

4 Learning Opportunities and Facilities Available for Employees ............. 27

$4.1 \quad$ Learning Opportunities Offered to Employees.........................................................27

4.2 Helping Employees Learn Things not Directly Connected to their Jobs....................29

4.3 Existence of Staff Association and Trade Union Representation ...............................31

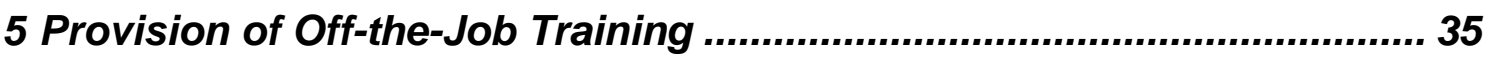

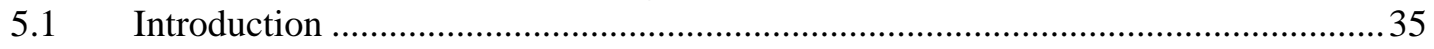

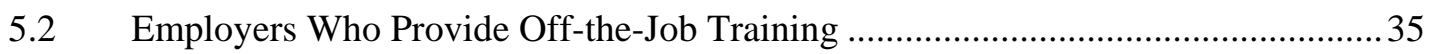

5.3 Proportion of Employees Receiving Off-the-Job Training.......................................... 37

5.4 Amount of Off-the-Job Training Provided .............................................................. 38

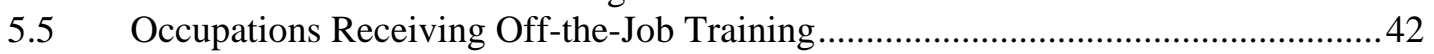


6 Management and Delivery of Off-the-Job Training ................................45

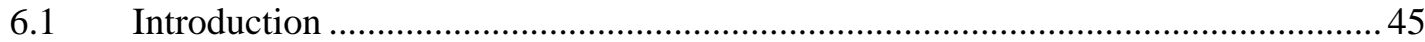

6.2 Existence of Business, Training and Human Resource Plans and Budgets .............. 45

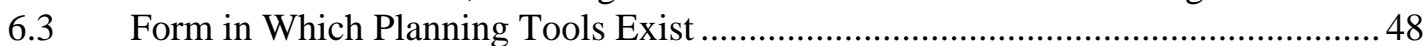

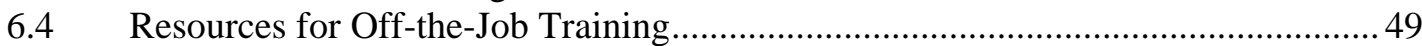

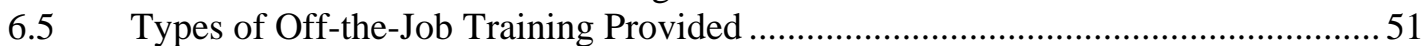

6.6 Off-the-Job Training Leading to Formal Qualifications ..........................................52

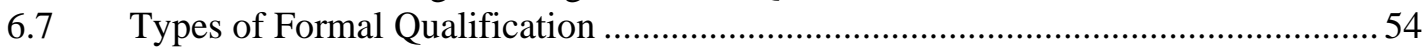

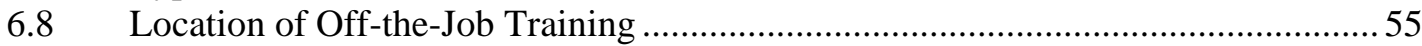

6.9 Satisfaction with Quality of Training Provided by Private Training Providers

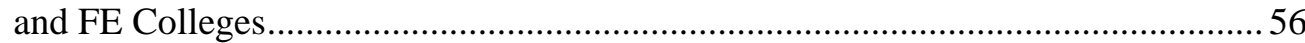

6.10 Methods of Providing Off-the-Job Training.............................................................5 57

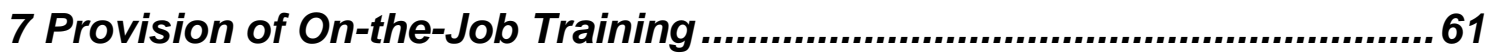

8 Provision of Job-Related Training and Reasons for Non-Provision ....... 65

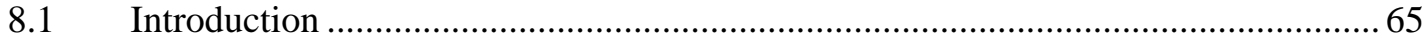

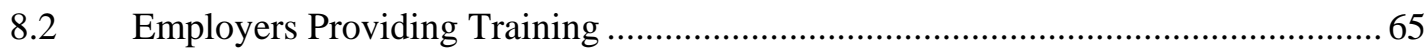

8.3 Reasons why Training not Provided over Previous 12 Months ................................68

9 Cost to Employers of Providing Job-Related Training ........................... 71

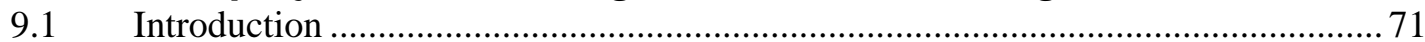

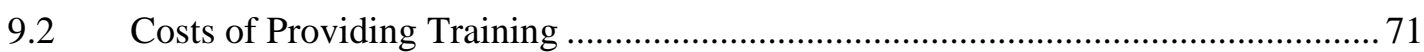

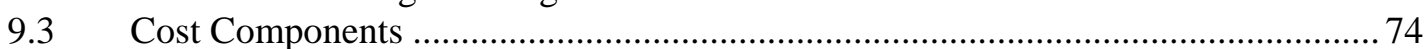

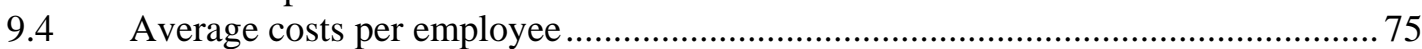

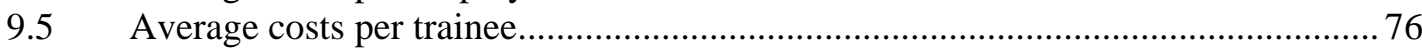

10 Awareness Of, and Involvement with, Training Initiatives ....................81

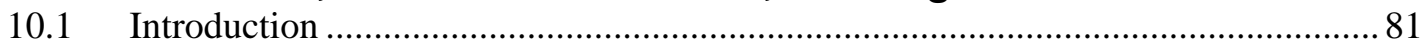

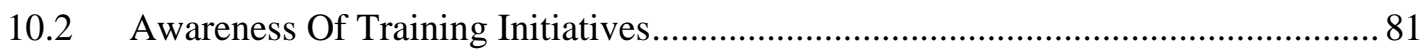

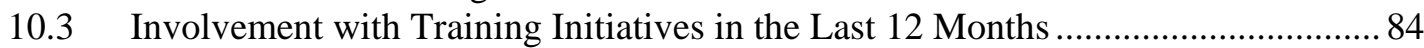

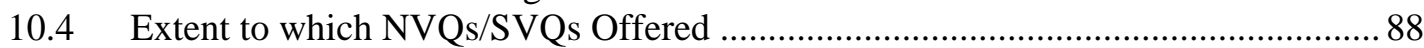

10.5 Average Proportion of Employees to whom NVQs/SVQs on Offer.........................99

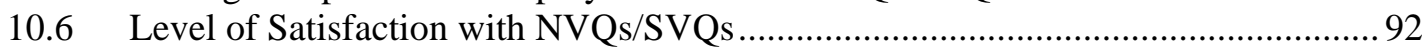

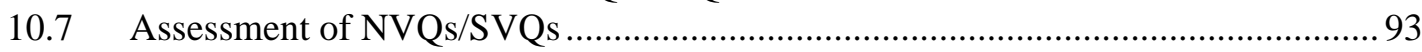

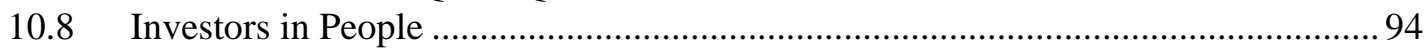

11 Young Employees Aged 16-24 .......................................................... 99

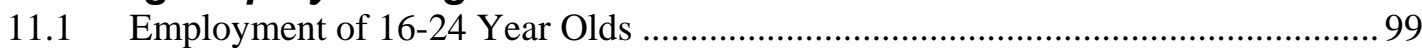

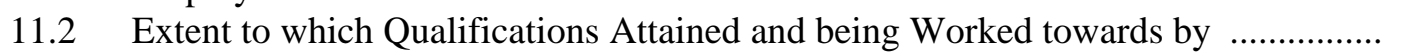

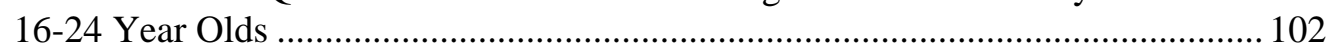

12 Comparison with Skill Needs in Britain Surveys.................................107

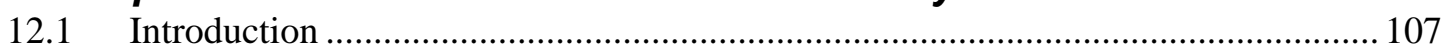

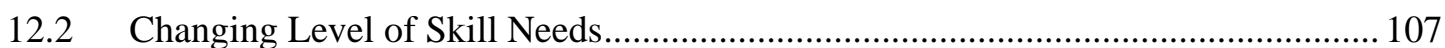

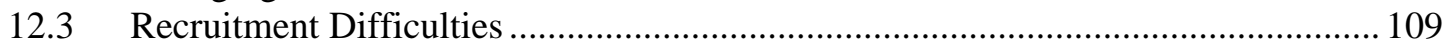

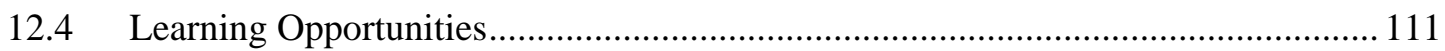

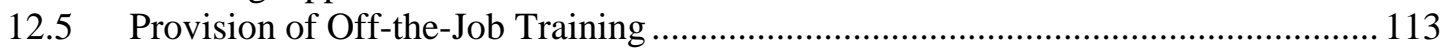

12.6 Management and Delivery of Off-the-Job Training ................................................ 117

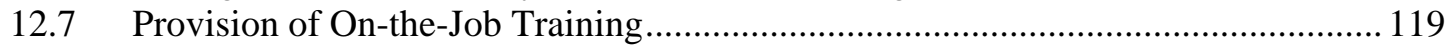

12.8 Awareness of, and Involvement with, Training Initiatives...................................... 121 
13 Technical Appendix

125

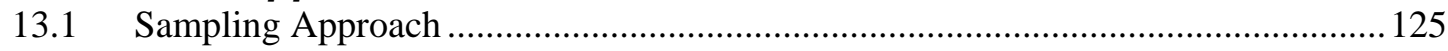

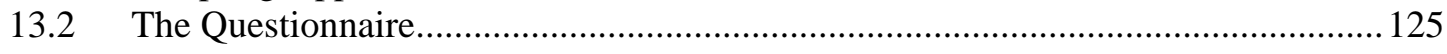

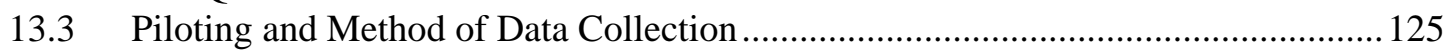

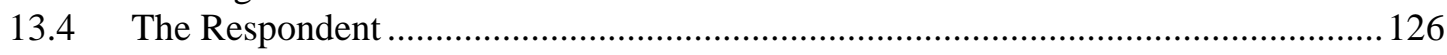

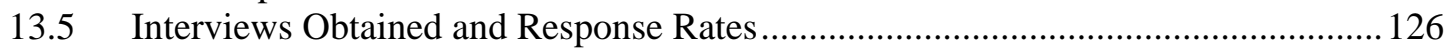

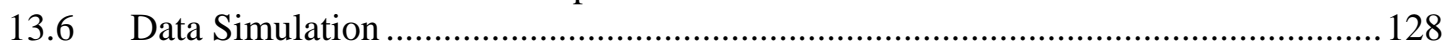

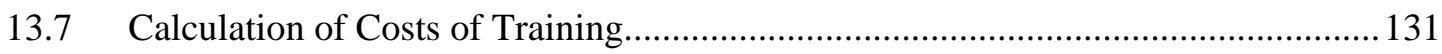

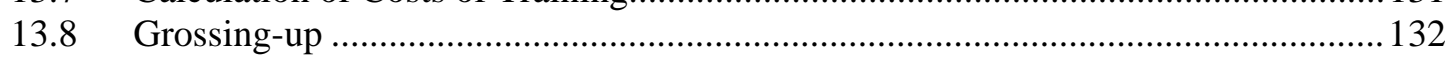

Questionnaires and Datasheet........................................................ 135 
Chapter 1

I ntroduction 


\section{Introduction}

\subsection{Background}

1.1.1 Learning and Training at Work (LTW) 2000 is the second in what is now an annual series of employer surveys that investigate the provision of learning and training at work. The survey also investigates awareness of, and involvement with, a number of existing and new training and development initiatives.

1.1.2 Learning and training information had previously been collected, along with information on recruitment difficulties, skill shortages and skill gaps, in the annual Skill Needs in Britain (SNIB) surveys, which were carried out between 1990 and 1998.

\subsection{Aims and Objectives}

1.2.1 The objectives of the 2000 Learning and Training at Work survey were to collect information about:

- Key indicators of employers' commitment to training, including the volume of off-thejob training provided

- Awareness of, and involvement with, a number of initiatives relevant to training

- The costs associated with the provision of training

The information collected will be used to inform policy decision making.

\section{$1.3 \quad$ Methodology}

1.3.1 The survey consisted of 4,001 telephone interviews with employers having 1 or more employees at the specific location sampled. All business sectors, public and private, were covered.

1.3.2 It is not feasible to collect the costs of providing training reliably in a single stage telephone interview for two reasons:

- Reference may need to be made to written records

- The single respondent interviewed may need to refer to other people at the establishment.

1.3.3 This information was therefore collected through a two stage process:

- A datasheet was mailed to those employers who stated during the telephone interview that they had provided training over the previous 12 months and asking them to complete it (if necessary, through reference to written records and/or colleagues)

- Recalling to collect the information on the telephone

1.3.4 Information on the costs of providing training was obtained from 924 employers, of which the results given by 883 were of sufficient quality to be useable in analysis.

1.3.5 A pilot of 200 interviews was conducted during May, prior to the main interviewing programme, in order to ensure the questionnaire, datasheet and the general approach met the objectives of the study.

1.3.6 All interviews were carried out from IFF's telephone centre in London by fully trained business-to-business interviewers. 
1.3.7 In the 2000 study, the main stage of interviewing was carried out between 17 July and 20 October: in the 1999 study fieldwork took place between 3 November and 21 December. Readers may wish to bear in mind the fact that fieldwork in the two surveys was not carried out at the same time of year and that employers' responses may be influenced by the timing of the fieldwork.

1.3.8 The average length of interview in the 2000 study, including the time taken to collect datasheet information, was 20 minutes.

1.3.9 The overall response rate to the main part of the survey from employers was $66 \%$. The response rate for the datasheet element was $24 \%$.

1.3.10 Fuller details of the methodology employed, in particular in relation to calculation of the costs of training, can be found in the Technical Appendix in Chapter 13.

\subsection{Sample Design}

1.4.1 Sample design involved setting separate sample targets for each cell on a Government Office region by industry sector by establishment size matrix.

1.4.2 Results were grossed up at the analysis stage to population estimates derived from the 1998 Annual Employment Survey. Results are therefore representative of the 2.1 million employers in England who have 1 or more employees. It should be noted that data shown for all employers is heavily influenced by the results for employers with 1-4 employees as $72 \%$ of employers fall into this category.

\subsection{Comparison with Skill Needs in Britain Surveys}

1.5.1 As mentioned previously, the 1999 and 2000 Learning and Training at Work studies covered employers in establishments with 1 or more employees in all business sectors in England. Chapters 3-11 present comparative results from these studies, when appropriate, broken down by establishment size, industry sector and region.

1.5.2 The SNIB surveys covered employers with 25 or more employees in all business sectors, except agriculture, hunting, forestry and fishing, in Great Britain.

1.5.3 Fieldwork for the 1997 SNIB study was carried out between 8 May and 27 June 1997. In the 1998 SNIB study fieldwork was carried out between 5 May and 26 June.

1.5.4 Given this differing coverage, we have therefore run analyses on the SNIB and Learning and Training at Work data, based on all employers with 25 or more employees in all business sectors except agriculture, hunting, forestry and fishing, in England. This has allowed us to compare results from the two series of surveys. These results are provided in Chapter 13.

1.5.5 In Chapter 2 results are summarised from both perspectives. 


\subsection{Reporting Conventions}

1.6.1 All data shown in this report are grossed up percentage data unless otherwise stated. The unweighted sample size from the 2000 study is shown at the foot of all tables to indicate to the reader the number of employers on whose responses the results are based. When appropriate, tables also show weighted figures for the number of employers in each industry sector, region or establishment size band, on which the percentages are based.

1.6.2 An asterisk has been used to signify a percentage of less than $0.5 \%$ and a - to indicate that a percentage is zero. In a few places the symbol $100^{*}$ has been used - this indicates a percentage of more than $99.5 \%$, which has been rounded up to $100 \%$. Percentages may add to just over or under $100 \%$, or absolute figures aggregated across sub-samples may not add exactly to the total, due to rounding. Where multiple answers were allowed the sum of the answers may exceed $100 \%$.

1.6.3 In most cases percentages reported have been calculated on those employers asked the question. However in a few places, for reasons of clarity, percentages have been rebased. In the tables and figures in this report the word "coverage" has been used to describe the employers asked the question and the word "base" to describe employers on which the results have been reported.

1.6.4 Results refer to the 2000 Learning and Training at Work survey unless otherwise indicated.

1.6.5 Much of the information collected has been shown in tabular or graphical form with appropriate written commentary on the findings. It is not the intention of this report to interpret findings.

1.6.6 When a question was asked of all employers, the results quoted are generally accurate, at $95 \%$ confidence levels, to $+/-1.5 \%$. Results reported for subsamples are subject to larger margins of error.

1.6.7 This means that if one is looking at the results given for two surveys in two different years, the percentages based on all employers need to differ by a minimum of $4 \%$ for the apparent differences to be statistically significant at $95 \%$ confidence levels.

1.6.8 Results concerned with the number of days of off-the-job training provided are less accurate than other results due to the difficulties that employers have in providing this information.

Results concerned with the costs of providing training are less accurate still due to the smaller number of responses from which the information has been calculated and the fact that many employers, through necessity, provided estimates rather than hard data. It is not possible to quote a precise level of accuracy but figures pertaining to the cost of training should be interpreted as best estimates rather than more definitive measurements.

1.6.9 The IFF personnel responsible for the study were David Spilsbury, Managing Director, and Jon Sanwell, Project Manager. 
Chapter 2

Summary of Findings 


\section{Summary of Findings}

\subsection{Introduction}

2.1.1 Learning and Training at Work 2000 is the second in an annual series of surveys amongst employers that investigates the provision of learning and training at work.

2.1.2 The objectives of the study were to collect information about:

- Key indicators of employers' commitment to training, including the volume of off-thejob training provided

- Employers' awareness of, and involvement with, a number of initiatives relevant to training.

- The costs associated with the provision of training.

2.1.3 The survey consisted of 4,001 telephone interviews with employers having 1 or more employee at the location sampled. All business sectors, private and public, were covered. Only employers in England were interviewed.

2.1.4 Information pertaining to the costs of training was collected through use of a datasheet. Employers who had provided training over the previous 12 months were sent a datasheet at the end of the interview and asked to complete this. They were then recalled by telephone and the information collected. Responses to this element of the study were obtained from 924 employers, of which those from 883 employers were useable in analysis. Because only a small number of datasheets were obtained from employers with 1-9 employees, it was not possible to project results from this group up to national estimates reliably. Therefore data pertaining to the costs of training relate to the 711 employers with 10 or more employees who returned the datasheet.

2.1.5 Much of the information collected in the Learning and Training at Work surveys had previously been collected in the annual Skill Needs in Britain (SNIB) surveys. The SNIB surveys covered employers in Great Britain with 25 or more employees. All business sectors with the exception of agriculture, hunting, forestry and fishing were covered.

2.1.6 As well as providing results from all employers interviewed on this and the 1999 Learning and Training at Work studies (sections 2.2-2.12), we have reanalysed the results from these two surveys and from the previous two SNIB studies so that comparative results over the last 4 years can be shown (sections 2.13-2.18). This data relates to employers in England with 25 or more employees in all business sectors except agriculture, hunting, forestry and fishing.

2.1.7 It should be noted that data in this report shown for all employers is heavily influenced by the results for employers with $1-4$ employees as $72 \%$ of employers fall into this category. 


\section{A) Learning and Training at Work 1999 and 2000 Surveys}

\subsection{Skill Needs and Recruitment Difficulties}

2.2.1 Over eight out of ten employers (84\%) in the 2000 study felt that all or nearly all of their existing staff were fully proficient at their current job. This compares with the $88 \%$ reported in the 1999 study. (ref. section 3.2)

2.2.2 Three out of five employers (61\%) believed that the skills needed in their average employee were increasing. In the 1999 study the proportion was very similar at $62 \%$. (ref. section 3.3)

2.2.3 One in six employers (17\%) in the 2000 study was experiencing a hard-to-fill vacancy at the time of interview. This represents an increase over the $10 \%$ of employers who were doing so in the 1999 study. (ref. section 3.4)

\subsection{Learning Opportunities and Facilities Available for Employees}

2.3.1 Almost two-thirds (63\%) of employers in 2000 offered at least one of eight nominated types of learning opportunity. Learning in information technology (43\%) and in managing their own development (41\%) were the most commonly offered. (ref. section 4.1 )

2.3.2 In the 1999 study a smaller proportion of employers (45\%) offered a learning opportunity. Learning in information technology was again the most commonly offered (32\%). (ref. section 4.1)

2.3.3 Over a quarter of employers (28\%) in the 2000 study helped employees learn skills not directly connected to their job. This is the same proportion as reported in the 1999 study. (ref. section 4.2)

2.3.4 Seven percent of employers in the 2000 study (1999 study : $8 \%$ ) reported that they had staff association or trade union representation at the establishment. In the majority of these establishments staff association or trade union representatives were formally discussing, promoting or directly providing learning or training opportunities to employees. (ref. section 4.3) 


\subsection{Provision of Off-the-Job Training}

2.4.1 Off-the-job training had been provided by two out of five employers $(41 \%)$ over the previous 12 months. This represents an increase over the 34\% reported in the 1999 study. (ref. section 5.2)

2.4.2 Overall, in the 2000 study, $26 \%$ of employees had received off-the-job training over the previous 12 months. This compares with the $22 \%$ who had done so in the 1999 study. (ref. section 5.3)

2.4.3 Over the last 12 months, in the 2000 study, employees receiving off-the-job training had on average received 8.2 days each. This equates to an average 2.2 days being provided per employee. The equivalent figures in the 1999 study were 8.6 days per employee trained and 1.9 days per employee. (ref. section 5.4)

\subsection{Management of Training and Training Delivery}

2.5.1 In the 2000 study, over half of employers (60\%) possessed a business plan, two out of five (39\%) had a training plan, over a quarter (27\%) had a training budget and just under a quarter (24\%) a human resource plan. (ref. section 6.2)

2.5.2 All four tools were more likely to be held as formal written documents than as something less formal. (ref. section 6.3)

2.5.3 Over two-thirds (71\%) of employers who had provided off-the-job training over the previous 12 months had a member of senior management with responsibility for training within the organisation (1999 study : 67\%). Staff to design and teach training courses and a separate training facility existed in $32 \%$ and $23 \%$ of organisations respectively.

(1999 study : 30\% and 23\%) (ref. section 6.4)

2.5.4 In the 2000 study, job specific and health and safety training were the types of training that had most commonly been provided by employers (each $69 \%$ of those who had provided offthe-job training). Around half had provided training in new technology and induction training (each 52\%). (ref. section 6.5)

2.5.5 Of those employers who had provided off-the-job training over the previous 12 months, $46 \%$ reported in the 2000 study that some of this training was leading to a formal qualification. This is similar to the $43 \%$ reported in the 1999 study. (ref. section 6.6) 


\subsection{Provision of On-the-Job Training}

2.6.1 Overall, two-thirds of employers (66\%) had carried out on-the-job training in the previous 12 months. This compares with the $58 \%$ reported in the 1999 study. (ref. section 7.1)

2.6.2 Training by a line manager or supervisor (78\% of those carrying out on-the-job training) and training by other experienced staff in the company (56\%) were the most common methods of providing on-the-job training in both years. (ref. section 7.1)

\subsection{Provision of Training and Reasons for Non-Provision}

2.7.1 In the 2000 study, three-quarters of employers (76\%) had provided employees at the location with either off-the-job or on-the-job training. This compares with the $68 \%$ reported in the 1999 study. (ref. section 8.2)

2.7.2 By far the most common reason for not having provided training was that employers felt the skills possessed by their employees currently met needs, so training was not necessary (ref. section 8.3)

\subsection{Costs of Job-Related Training}

2.8.1 The total cost to employers with 10 or more employees of providing job-related training over the previous 12 months is estimated to be $£ 23.5 \mathrm{bn}$. (ref. section 9.2)

2.8.2 Of this figure, off-the-job training accounts for $£ 14.5 \mathrm{bn}$, of which $£ 11.8 \mathrm{bn}$ relates to training courses and $£ 2.8 \mathrm{bn}$ to other forms of off-the-job training such as seminars and workshops, and on-the-job training accounts for $£ 9.0 \mathrm{bn}$. (ref. section 9.2)

2.8.3 The average cost per employee of providing training was $£ 1024$. The average cost per employee of providing off-the-job training was $£ 632$ and of on-the-job training $£ 393$. (ref. section 9.4) 


\subsection{Awareness of Training Initiatives}

2.9.1 NVQs are the initiative with the highest level of awareness amongst employers, with a large majority (90\%) having heard of them (1999 study : 86\%). At least half had heard of Youth Training (63\%), Modern Apprenticeships (recently relaunched as Advanced Modern Apprenticeships) (61\%) and the National Record of Achievement (53\%). (1999 study : 62\%, $55 \%$ and $45 \%$ respectively) (ref. section 10.2 )

\subsection{NVQs}

2.10.1 In the 2000 study, $18 \%$ of employers aware of NVQs were currently offering the qualification to at least some of their employees. This is slightly higher than the $16 \%$ who were doing so in the 1999 study. (ref. section 10.4)

2.10.2 In the 2000 study, where NVQs were on offer, they were on offer to $39 \%$ of employees. This equates to the qualification being offered to $17 \%$ of employees overall. (ref. section 10.5)

2.10.3 Three-quarters of employers (75\%) who offer NVQs were either very or fairly satisfied with them (1999 study : 78\%). This high level of satisfaction mainly stems from a feeling that the qualification had improved the level of knowledge of their workforce. (ref. section 10.6)

2.10.4 Approaching two-thirds (62\%) of employers offering NVQs felt that the quality of assessment was either very or fairly good. The equivalent figure in the 1999 study was 61\%. (ref. section 10.7)

\subsection{Investors in People}

2.11.1 Sixteen percent of employers in the 2000 study reported that their establishment had been formally recognised as an Investor in People (no equivalent data for 1999 available). (ref. section 10.8)

\subsection{Young Employees}

2.12.1 Approaching half of employers (45\%) employed 16-24 year olds, with 20-24 year olds being most commonly employed (1999 study : 37\%). (ref. section 11.1)

2.12.2 The proportion of employers in the 2000 study employing younger employees reporting that at least some had obtained a Level 2 or equivalent qualification was $61 \%$ for $16-17$ year olds, $73 \%$ for $18-19$ year olds and $75 \%$ for $20-24$ year olds. These proportions are all higher than those reported in the 1999 study $-49 \%, 67 \%$ and $72 \%$ respectively. (ref. section 11.2)

2.12.3 The proportion of employers in the 2000 study stating that at least some had obtained a Level 3 or equivalent qualification were $12 \%$ for $16-17$ year olds, 34\% for $18-19$ year olds and $51 \%$ for $20-24$ year olds. Again, these figures are higher than those reported in the 1999 study $-10 \%, 29 \%$ and $47 \%$ respectively. (ref. section 11.2 ) 


\section{B) Comparison with SNIB 97 and 98 and Learning and Training at Work 1999 Surveys (ref. section 12)}

The figures for 1999 and 2000 are often substantially different to the figures that have been reported in sections 2.2 to 2.12 , as the large number of small employers that dominated the full LTW weighted results are excluded here.

\subsection{Skill Needs and Recruitment Difficulties}

2.13.1 Over the past four years, around $70 \%$ of employers believed that the skills needed by their average employee in order to meet their business objectives have increased.

2.13.2 The proportion of employers experiencing a hard-to-fill vacancy at the time of interview was $18 \%$ in the 1997 study, 24\% in the 1998 study, 23\% in the 1999 study, and 30\% in the 2000 study.

\subsection{Learning Opportunities and Facilities Available for Employees}

(data not available from the 1997 study)

2.14.1 The proportion of employers offering one of eight specified learning opportunities to employees has increased from $67 \%$ in the 1998 study to $75 \%$ in the 1999 study to $86 \%$ in the 2000 study.

2.14.2 The proportion of employers having a staff association or trade union representation was $28 \%$ in the 1998 study, $37 \%$ in the 1999 study and $32 \%$ in the 2000 study.

\subsection{Provision of Off-the-Job Training}

2.15.1 Information on the provision of off-the-job training collected in the 1999 and 2000 studies may not be strictly comparable with that obtained in the 1997 and 1998 surveys due to a change in question wording that may have led to 1999 and 2000 figures being underestimates.

2.15.2 The proportion of employers reporting that they had provided off-the-job training over the previous 12 months was very similar in the 1997, 1998 and 2000 studies $(82 \%, 83 \%$ and $81 \%$ respectively). It was lower in the 1999 study at $75 \%$.

2.15.3 The proportion of employees who had received off-the-job training declined between 1997 and 1999 from the $41 \%$ reported in 1997 slightly to $38 \%$ in the 1998 study to $24 \%$ in the 1999 study. In the 2000 study the proportion has increased slightly to $28 \%$.

2.15.4 The average number of days off-the-job training received per employee trained increased from 1997 to 1999 from 7.9 to 8.5 to 9.4 days. In 2000 the figure was 8.1 days. 


\subsection{Management and Delivery of Off-the-Job Training}

2.16.1 The proportion of employers reporting that they have a training plan has increased from $65 \%$ in the 1997 study to $72 \%$ in the 2000 study. The proportion having a training budget has increased from $63 \%$ to $69 \%$ over this period.

2.16.2 The proportion of employers having a separate training facility has increased from $30 \%$ in the 1997 study to $38 \%$ in the most recent study. The proportion having staff to design and teach training courses has increased from 39\% to 50\% between the 1998 (the first year for which data are available) and the 2000 studies.

2.16.3 The proportion of employers who have provided off-the-job training over the previous twelve months reporting that at least some of this training was leading to formal qualifications remained constant between the 1997 and 1998 studies at 65\%, declined slightly to 62\% in 1999 and has increased to $67 \%$ in the most recent study.

\subsection{Provision of On-the-Job Training}

2.17.1 In the 1998 study nine out of ten employers (90\%) reported that they had carried out on-thejob training in the previous twelve months. The figure in the 1999 study was $86 \%$ and in the 2000 study 90\%. ( data not available from the 1997 study).

\subsection{Awareness of, and Involvement with, Training Initiatives}

2.18.1 Awareness of NVQs has been high in all four years, ranging from $96 \%$ in the 1997 study to $99 \%$ in the 2000 study. Awareness of Modern Apprenticeships (recently relaunched as Advanced Modern Apprenticeships) has been around $75 \%$ in all four years, ranging from $72 \%$ in the 1999 study to $78 \%$ in the 2000 study.

2.18.2 The proportion of employers involved with NVQs was $52 \%$ in $1997,50 \%$ in $1998,58 \%$ in 1999 and $48 \%$ in the most recent study. Equivalent figures for Modern Apprenticeships are $15 \%, 15 \%, 18 \%$ and $17 \%$.

2.18.3 The proportion of employers aware of NVQs who were offering the qualification to employees at the time of interview was $41 \%$ in the 1997 study, $47 \%$ in the 1999 study and $43 \%$ in the most recent study (equivalent data are not available from the 1998 study). 
Chapter 3 Skill Needs and Recruitment Difficulties 


\section{$3 \quad$ Skill Needs and Recruitment Difficulties}

\section{$3.1 \quad$ Introduction}

3.1.1 This section explores employers' views on the proficiency of their existing staff, whether they felt the skills required to ensure the effective operation of their business were increasing, decreasing or static, and whether or not they were experiencing a hard-to-fill vacancy at the time of interview.

\subsection{Proficiency of Existing Staff}

3.2.1 Over eight out of ten employers (84\%) felt that all or nearly all of their existing staff were fully proficient at their current job. It should be noted that no definition of "proficiency at their current job" was given to employers.

The results are similar to those reported in the 1999 study.

Fig 1

Proportion of staff fully proficient at current job

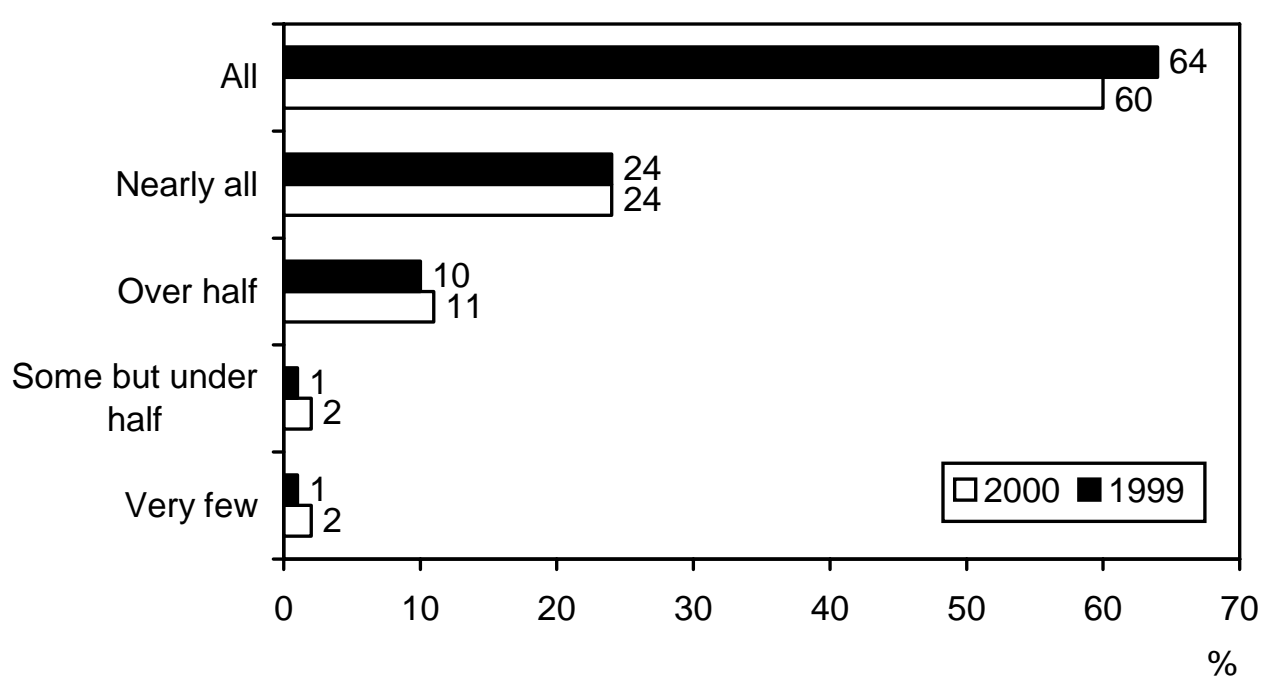

Base/Coverage : all employers - 4001 
3.2.2 In the 2000 study, as the size of the establishment increases, the proportion of employers feeling that all staff are fully proficient declines.

Table 1 Proportion of staff fully proficient at current job by size of employer

\begin{tabular}{|c|c|c|c|c|c|c|c|}
\hline & Total & $1-4$ & $5-24$ & $25-99$ & $100-199$ & $200-499$ & $500+$ \\
\hline & $\%$ & $\%$ & $\%$ & $\%$ & $\%$ & $\%$ & $\%$ \\
\hline All & 60 & 72 & 36 & 19 & 13 & 13 & 10 \\
\hline Nearly all & 24 & 16 & 40 & 53 & 64 & 59 & 58 \\
\hline Over half & 11 & 8 & 18 & 22 & 20 & 25 & 25 \\
\hline Some but under half & 2 & 2 & 3 & 4 & 3 & 1 & 2 \\
\hline Very few & 2 & 2 & 3 & 1 & 1 & - & * \\
\hline Not stated & 1 & 1 & * & 1 & 1 & 2 & 5 \\
\hline $\begin{array}{l}\text { Total no. of employers } \\
\text { Base/Coverage: all emp }\end{array}$ & $\begin{array}{l}2055656 \\
s-4001\end{array}$ & 1480267 & 428851 & 117187 & 17155 & 9163 & 3033 \\
\hline
\end{tabular}

3.2.3 In the 2000 study, employers in the manufacturing sector were most likely to indicate a lack of proficiency amongst their existing staff.

Table 2 Proportion of staff fully proficient at current job by industry sector of employer

\begin{tabular}{lcccccc}
\hline & Total & $\begin{array}{c}\text { Manufac- } \\
\text { turing }\end{array}$ & $\begin{array}{c}\text { Agriculture } \\
\text { mining, } \\
\text { construction, } \\
\text { utilities }\end{array}$ & $\begin{array}{c}\text { Distribution } \\
\text { \& consumer } \\
\text { services }\end{array}$ & $\begin{array}{c}\text { Finance \& \& } \\
\text { business } \\
\text { services }\end{array}$ & $\begin{array}{c}\text { Transport, } \\
\text { public admin, } \\
\text { other } \\
\text { services }\end{array}$ \\
& $\%$ & $\%$ & $\%$ & $\%$ & $\%$ & $\%$ \\
\hline All & 60 & 49 & 67 & 59 & 66 & 55 \\
Nearly all & 24 & 29 & 20 & 24 & 21 & 28 \\
Over half & 11 & 13 & 8 & 12 & 10 & 12 \\
Some but under half & 2 & 4 & 2 & 2 & 2 & 2 \\
Very few & 2 & 3 & 1 & 2 & 2 & 1 \\
Not stated & 1 & 1 & 1 & 1 & $*$ & 1 \\
\hline Total no. of employers & 2055656 & 183042 & 250929 & 624092 & 559591 & 438002 \\
Base/Coverage : all employers -4001 & & & & &
\end{tabular}

3.2.4 Results for the 2000 study are shown by region below:

Table 3 Proportion of staff fully proficient at current job by Government Office region of employer

\begin{tabular}{|c|c|c|c|c|c|c|c|c|c|c|}
\hline & Total & $\begin{array}{c}\text { North } \\
\text { East } \\
0\end{array}$ & $\begin{array}{l}\text { North } \\
\text { West }\end{array}$ & $\begin{array}{l}\text { Yorkshire } \\
\text { and the } \\
\text { Humber }\end{array}$ & $\begin{array}{c}\text { East } \\
\text { Midlands }\end{array}$ & $\begin{array}{c}\text { West } \\
\text { Midlands }\end{array}$ & Eastern & London & $\begin{array}{c}\text { South } \\
\text { East }\end{array}$ & $\begin{array}{l}\text { South } \\
\text { West }\end{array}$ \\
\hline & $\%$ & $\%$ & $\%$ & $\%$ & $\%$ & $\%$ & $\%$ & $\%$ & $\%$ & $\%$ \\
\hline All & 60 & 49 & 54 & 54 & 56 & 62 & 57 & 60 & 71 & 64 \\
\hline Nearly all & 24 & 25 & 28 & 24 & 28 & 17 & 29 & 23 & 19 & 27 \\
\hline Over half & 11 & 18 & 10 & 15 & 12 & 16 & 10 & 13 & 6 & 8 \\
\hline Some but under half & 2 & 5 & 2 & 3 & 4 & 1 & 1 & 3 & 2 & 1 \\
\hline Very few & 2 & 3 & 2 & 3 & * & 4 & 3 & 1 & 1 & * \\
\hline Not stated & 1 & * & 4 & 1 & * & * & * & 1 & * & 1 \\
\hline $\begin{array}{l}\text { Total no. of employers } \\
\text { Base/Coverage: all empl }\end{array}$ & $\begin{array}{l}2055656 \\
s-400\end{array}$ & 71976 & 245697 & 179373 & 161272 & 200189 & 33332 & 382198 & & 1558 \\
\hline
\end{tabular}




\subsection{Changes in Skill Needs}

3.3.1 Three out of five employers (61\%) believed that the skills needed in their average employee were increasing.

This figure is very similar to that reported in the 1999 study $-62 \%$.

Fig 2 Skills needed in average employee

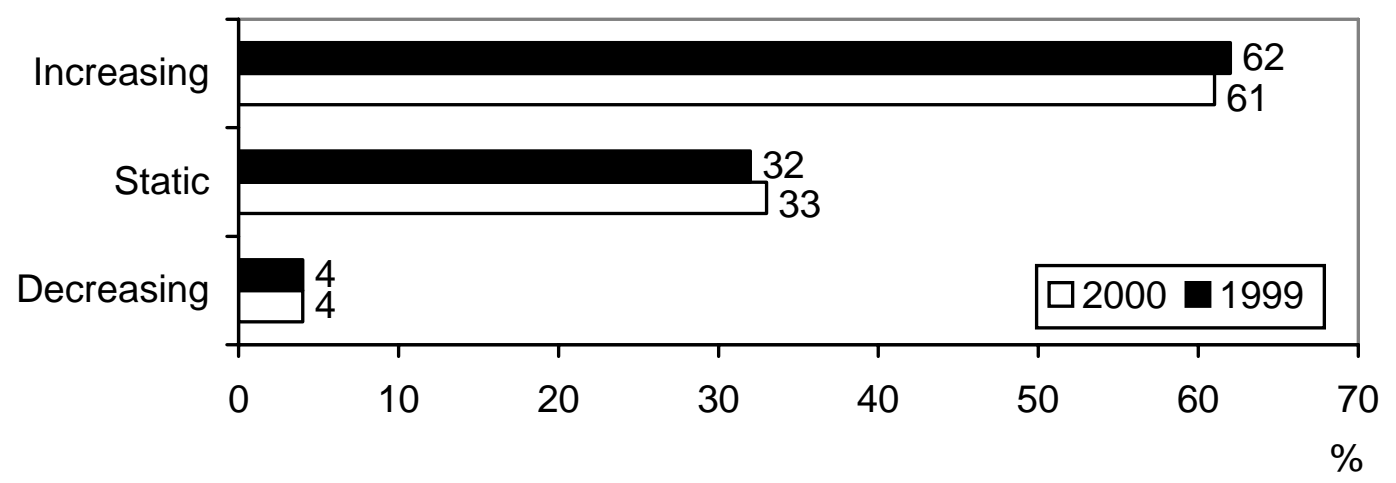

Base/Coverage : all employers - 4001

3.3.2 The table below shows the general trend that the larger the employer the more likely they were to feel the skills required of an average employee were increasing.

Table $4 \quad$ Increasing skill needs in average employee by size of employer

\begin{tabular}{lccc}
\hline & $\begin{array}{c}\mathbf{1 9 9 9} \\
\%\end{array}$ & $\begin{array}{c}\mathbf{2 0 0 0} \\
\%\end{array}$ & $\begin{array}{c}\text { Total no } \\
\text { of employers }\end{array}$ \\
\hline $1-4$ & 60 & 58 & 1480267 \\
$5-24$ & 65 & 67 & 428851 \\
$25-99$ & 71 & 69 & 117187 \\
$100-199$ & 72 & 71 & 17155 \\
$200-499$ & 71 & 76 & 9163 \\
$500+$ & 77 & 84 & 3033 \\
TOTAL & 62 & 61 & 2055656 \\
\hline
\end{tabular}

Base/Coverage: all employers -4001 
3.3.3 The transport, public administration and other services and the finance and business services sectors are the sectors in which the highest proportion of employers felt the skill needs of their average employee were increasing

Table 5 Increasing skill needs in average employee by industry sector of employer

\begin{tabular}{lccc}
\hline & $\begin{array}{c}1999 \\
\%\end{array}$ & $\begin{array}{c}\mathbf{2 0 0 0} \\
\%\end{array}$ & $\begin{array}{c}\text { Total no. } \\
\text { of employers }\end{array}$ \\
\hline Manufacturing & 56 & 62 & 183042 \\
Agriculture, mining, utilities \& construction & 60 & 52 & 250929 \\
Distribution \& consumer services & 55 & 50 & 624092 \\
Finance \& business services & 73 & 66 & 559591 \\
Transport, public admin \& other services & 63 & 73 & 438002 \\
TOTAL & 62 & 61 & 2055656 \\
\hline
\end{tabular}

Base/Coverage: all employers - 4001

3.3.4 The proportion of employers in each region feeling that the skills needed in their average employee were increasing is shown below.

Table 6 Increasing skill needs in average employee by Government Office region of employer

\begin{tabular}{lccc}
\hline & $\mathbf{1 9 9 9}$ & $\mathbf{2 0 0 0}$ & $\begin{array}{c}\text { Total no. } \\
\text { of employers }\end{array}$ \\
\hline North East & $\%$ & $\%$ & 71976 \\
North West & 52 & 54 & 245697 \\
Yorkshire and the Humber & 60 & 63 & 179373 \\
East Midlands & 57 & 68 & 161272 \\
West Midlands & 65 & 62 & 200189 \\
Eastern & 58 & 56 & 233332 \\
London & 60 & 61 & 382198 \\
South East & 63 & 64 & 366035 \\
South West & 70 & 55 & 215584 \\
TOTAL & 64 & 59 & \\
\hline Base/Coverage: all employers -4001 & 62 & 61 & 2055656 \\
\hline
\end{tabular}

Base/Coverage: all employers - 4001 


\subsection{Recruitment Difficulties}

3.4.1 Employers were asked whether or not they were experiencing a hard-to-fill vacancy at the time of interview.

It should be noted that no formal definition of hard-to-fill vacancy was given to employers - it was left to each individual employer to interpret the phrase as they saw fit.

3.4.2 Overall, one in six employers (17\%) reported a hard-to-fill vacancy at the time of interview. This represents an increase over the level reported in the 1999 study when 10\% of employers did so.

3.4.3 In both the 1999 and the 2000 studies, the existence of hard-to-fill vacancies increased with increasing size of employer. This is what would be expected intuitively as larger employers are more likely to have a hard-to-fill vacancy simply because they employ more people.

Table 7 Existence of current hard-to-fill vacancies by size of employer

\begin{tabular}{lccc}
\hline & $\begin{array}{c}1999 \\
\%\end{array}$ & $\begin{array}{c}\mathbf{2 0 0 0} \\
\%\end{array}$ & $\begin{array}{c}\text { Total no } \\
\text { of employers }\end{array}$ \\
\hline $1-4$ & 7 & 15 & 1480267 \\
$5-24$ & 16 & 20 & 428851 \\
$25-99$ & 23 & 29 & 117187 \\
$100-199$ & 26 & 35 & 17155 \\
$200-499$ & 29 & 32 & 9163 \\
$500+$ & 29 & 42 & 3033 \\
TOTAL & 10 & 17 & 2055656 \\
\hline
\end{tabular}

Base/Coverage: all employers - 4001

3.4.4 In the 2000 study, employers in the distribution and consumer services sector were experiencing the highest level of hard-to-fill vacancies at the time of interview.

Table 8 Existence of current hard-to-fill vacancies by industry sector of employer

\begin{tabular}{|c|c|c|c|}
\hline & $\begin{array}{c}1999 \\
\%\end{array}$ & $\begin{array}{c}2000 \\
\%\end{array}$ & $\begin{array}{c}\text { Total no. } \\
\text { of employers }\end{array}$ \\
\hline Manufacturing & 15 & 17 & 183042 \\
\hline Agriculture, mining, utilities \& construction & 9 & 16 & 250929 \\
\hline Distribution \& consumer services & 12 & 20 & 624092 \\
\hline Finance \& business services & 8 & 14 & 559591 \\
\hline Transport, public admin \& other services & 11 & 18 & 438002 \\
\hline TOTAL & 10 & 17 & 2055656 \\
\hline
\end{tabular}

Base/Coverage: all employers - 4001 
3.4.5 In the 2000 study employers in the East Midlands, the South East and in Yorkshire and the Humber were more likely to report a hard-to-fill vacancy at the time of interview than the national average.

Table 9 Existence of current hard-to-fill vacancies by Government Office region of employer

\begin{tabular}{lccc}
\hline & $\mathbf{1 9 9 9}$ & $\mathbf{2 0 0 0}$ & $\begin{array}{c}\text { Total no. } \\
\text { of employers }\end{array}$ \\
\hline North East & 4 & $\%$ & 71976 \\
North West & 15 & 14 & 245697 \\
Yorkshire and the Humber & 7 & 20 & 179373 \\
East Midlands & 4 & 26 & 161272 \\
West Midlands & 10 & 9 & 200189 \\
Eastern & 10 & 15 & 233332 \\
London & 9 & 17 & 382198 \\
South East & 14 & 22 & 366035 \\
South West & 10 & 14 & 215584 \\
& & & \\
TOTAL & 10 & 17 & 2055656 \\
\hline
\end{tabular}

Base/Coverage: all employers - 4001 
Chapter 4 Learning Opportunities and Facilities Available for Employees 


\section{$4 \quad$ Learning Opportunities and Facilities Available for Employees}

\subsection{Learning Opportunities Offered to Employees}

4.1.1 Employers were asked which, if any, of a number of learning opportunities they offered to employees at the location.

4.1.2 Overall, almost two-thirds (63\%) offered at least one of the eight types of learning opportunity discussed. Learning in information technology (43\%), managing their own development (41\%) and working with others (38\%) were the types most commonly offered.

The proportion of employers offering learning opportunities has increased considerably since the 1999 study when only $45 \%$ did so. All eight types of learning opportunity are now being offered by more employers.

\section{Fig $3 \quad$ Learning opportunities offered}

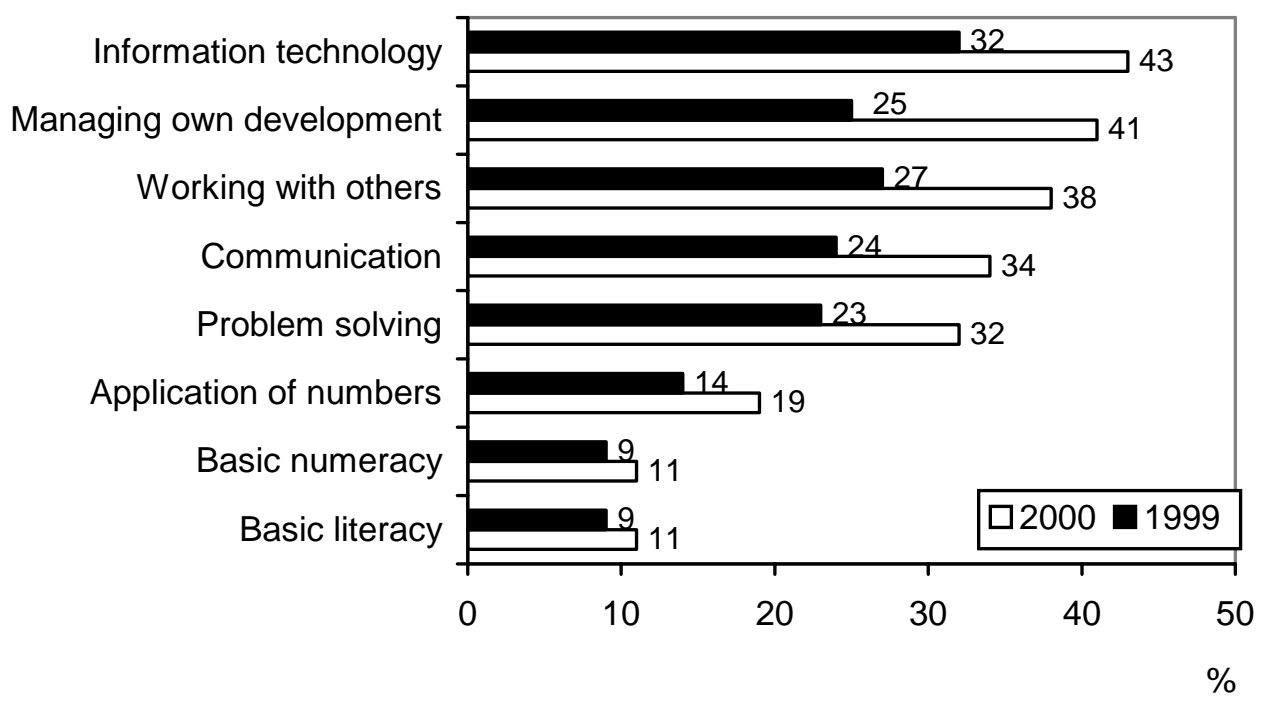

Base/Coverage : all employers - 4001 
4.1.3 The tendency to offer all eight types of learning opportunity increased with increasing employer size.

Table 10 Learning opportunities offered by size of employer

\begin{tabular}{|c|c|c|c|c|c|c|c|}
\hline & Total & $\begin{array}{c}1-4 \\
0\end{array}$ & $5-24$ & 25-99 & 100-199 & $\begin{array}{c}200- \\
499\end{array}$ & $500+$ \\
\hline Information technology & $\frac{\%}{43}$ & $\frac{\%}{38}$ & $\frac{\%}{51}$ & $\frac{\%}{67}$ & $\frac{\%}{80}$ & $\begin{array}{l}\% \\
88\end{array}$ & $\frac{\%}{94}$ \\
\hline Managing own development & 41 & 36 & 47 & 61 & 68 & 75 & 85 \\
\hline Working with others & 38 & 32 & 49 & 62 & 68 & 79 & 86 \\
\hline $\begin{array}{l}\text { Communication (through either } \\
\text { Written work or oral presentation) }\end{array}$ & 34 & 29 & 41 & 57 & 68 & 77 & 87 \\
\hline Problem solving & 32 & 28 & 40 & 51 & 60 & 64 & 80 \\
\hline Application of numbers & 19 & 18 & 23 & 26 & 28 & 37 & 44 \\
\hline Basic numeracy & 11 & 9 & 13 & 15 & 19 & 29 & 36 \\
\hline Basic literacy & 11 & 10 & 12 & 15 & 18 & 30 & 37 \\
\hline Any of the above & 63 & 58 & 73 & 84 & 91 & 96 & 99 \\
\hline $\begin{array}{l}\text { Total no. of employers } \\
\text { Base/Coverage: all employers }-4001\end{array}$ & 2055656 & 1480267 & 428851 & 117187 & 17155 & 9163 & 3033 \\
\hline
\end{tabular}

4.1.4 Employers in the transport, public administration and other services and in the finance and business services sectors were more likely to offer a wider range of learning opportunities than those in other sectors.

Table 11 Learning opportunities offered by industry sector of employer

\begin{tabular}{|c|c|c|c|c|c|c|}
\hline & $\begin{array}{c}\text { Total } \\
\%\end{array}$ & $\begin{array}{c}\text { Manufac- } \\
\text { turing } \\
\% \\
\end{array}$ & $\begin{array}{c}\text { Agriculture } \\
\text { mining, } \\
\text { construction, } \\
\text { utilities } \\
\% \\
\end{array}$ & $\begin{array}{c}\text { Distribution \& } \\
\text { consumer } \\
\text { services } \\
\% \\
\end{array}$ & $\begin{array}{c}\text { Finance } \\
\& \\
\text { business } \\
\text { services } \\
\% \\
\end{array}$ & $\begin{array}{c}\text { Transport, } \\
\text { public } \\
\text { admin, } \\
\text { other } \\
\text { services } \\
\% \\
\end{array}$ \\
\hline Information technology & 43 & 41 & 29 & 33 & 52 & 55 \\
\hline Managing own development & 41 & 33 & 26 & 40 & 42 & 51 \\
\hline Working with others & 38 & 34 & 20 & 47 & 32 & 45 \\
\hline $\begin{array}{l}\text { Communication (through either } \\
\text { Written work or oral presentation) }\end{array}$ & 34 & 23 & 13 & 39 & 32 & 46 \\
\hline Problem solving & 32 & 30 & 20 & 31 & 37 & 35 \\
\hline Application of numbers & 19 & 19 & 10 & 23 & 20 & 19 \\
\hline Basic numeracy & 11 & 11 & 6 & 13 & 10 & 11 \\
\hline Basic literacy & 11 & 12 & 5 & 12 & 10 & 13 \\
\hline Any of above & 63 & 57 & 45 & 63 & 67 & 72 \\
\hline $\begin{array}{l}\text { Total no. of employers } \\
\text { Base/Coverage: all employers - } 4001\end{array}$ & 055656 & 183042 & 250929 & 624092 & 559591 & 438002 \\
\hline
\end{tabular}

4.1.5 Employers in Yorkshire and the Humber and in the North West were most likely to offer learning opportunities (72\% and $71 \%$ respectively) and those in the South East (53\%) least likely to do so. 


\subsection{Helping Employees Learn Things not Directly Connected to their Jobs}

4.2.1 Employers were asked whether they helped employees learn things not directly connected to their job.

4.2.2 In both the 2000 and the 1999 studies over a quarter of employers (28\%) did so.

4.2.3 The proportion of employers who offer employees learning opportunities not directly connected to employees' jobs, broadly speaking, increases with increasing size of employer.

Table 12 Offer of learning activities not directly connected to employees' jobs by size of employer

\begin{tabular}{lccc}
\hline & $\mathbf{1 9 9 9}$ & $\mathbf{2 0 0 0}$ & $\begin{array}{c}\text { Total no. } \\
\text { of employers }\end{array}$ \\
\hline $1-4$ & 28 & 27 & 1480267 \\
$5-24$ & 27 & 32 & 428851 \\
$25-99$ & 33 & 30 & 117187 \\
$100-199$ & 36 & 36 & 17155 \\
$200-499$ & 45 & 49 & 9163 \\
$500+$ & 51 & 53 & 3033 \\
TOTAL & 28 & 28 & 2055656 \\
\hline
\end{tabular}

Base/Coverage: all employers -4001

4.2.4 Employers in service sectors are more likely to offer these learning opportunities than those in other sectors.

Table 13 Offer of learning activities not directly connected to employees' jobs by industry sector of employer

\begin{tabular}{|c|c|c|c|}
\hline & $\begin{array}{c}1999 \\
\%\end{array}$ & $\begin{array}{c}2000 \\
\%\end{array}$ & $\begin{array}{c}\text { Total no. } \\
\text { of employers }\end{array}$ \\
\hline Manufacturing & 23 & 28 & 183042 \\
\hline Agriculture, mining, utilities \& construction & 19 & 23 & 250929 \\
\hline Distribution \& consumer services & 24 & 29 & 624092 \\
\hline Finance \& business services & 33 & 28 & 559591 \\
\hline Transport, public admin \& other services & 36 & 32 & 438002 \\
\hline TOTAL & 28 & 28 & 2055656 \\
\hline
\end{tabular}


4.2.5 The proportion of employers offering these learning opportunities varies by region as shown below.

Table 14 Offer of learning activities not directly connected to employees' jobs by Government Office region of employer

\begin{tabular}{lccc}
\hline & $\begin{array}{c}\mathbf{1 9 9 9} \\
\%\end{array}$ & $\begin{array}{c}\mathbf{2 0 0 0} \\
\%\end{array}$ & $\begin{array}{c}\text { Total no } \\
\text { of employers }\end{array}$ \\
\hline North East & 31 & 32 & 71976 \\
North West & 30 & 28 & 245697 \\
Yorkshire and the Humber & 37 & 21 & 179373 \\
East Midlands & 35 & 30 & 161272 \\
West Midlands & 20 & 29 & 200189 \\
Eastern & 21 & 22 & 233332 \\
London & 23 & 29 & 382198 \\
South East & 36 & 33 & 366035 \\
South West & 26 & 30 & 215584 \\
TOTAL & 28 & & \\
\hline
\end{tabular}

Base/Coverage: all employers - 4001 


\subsection{Existence of Staff Association and Trade Union Representation}

4.3.1 Employers were asked whether or not they had staff association or trade union representation at the location and, if so, whether representatives were involved in promoting or providing learning or training opportunities.

4.3.2 In the 2000 study, $7 \%$ of employers reported that they had trade union or staff association representation : the comparable figure in the 1999 study was $8 \%$.

4.3.3 Staff association or trade union representation is much more likely to exist in larger establishments than in smaller ones.

Table 15 Existence of staff association or trade union representation by size of employer

\begin{tabular}{lccc}
\hline & $\mathbf{1 9 9 9}$ & $\mathbf{2 0 0 0}$ & $\begin{array}{c}\text { Total no. } \\
\text { of employers }\end{array}$ \\
\hline $1-4$ & $\%$ & $\%$ & 1480267 \\
$5-24$ & 4 & 4 & 428851 \\
$25-99$ & 11 & 8 & 117187 \\
$100-199$ & 32 & 26 & 17155 \\
$200-499$ & 47 & 44 & 9163 \\
$500+$ & 61 & 62 & 3033 \\
TOTAL & 76 & 78 & \\
\hline Baser & & & \\
\end{tabular}

Base/Coverage: all employers - 4001

4.3.4 Staff association or trade union representation is considerably more likely to exist in the transport, public administration and other services sector than in other sectors.

Table 16 Existence of staff association or trade union representation by industry sector of employer

\begin{tabular}{lccc}
\hline & $\mathbf{1 9 9 9}$ & $\mathbf{2 0 0 0}$ & $\begin{array}{c}\text { Total no. } \\
\text { of employers }\end{array}$ \\
\hline Manufacturing & $\%$ & 7 & 183042 \\
Agriculture, mining, utilities \& construction & 4 & 2 & 250929 \\
Distribution \& consumer services & 5 & 4 & 624092 \\
Finance \& business services & 4 & 5 & 559591 \\
Transport, public admin \& other services & 19 & 16 & 438002 \\
TOTAL & & & \\
\hline
\end{tabular}

Base/Coverage: all employers - 4001 
4.3.5 London is the region in which the existence of staff association or trade union representation is greatest.

Table 17 Existence of staff association or trade union representation by Government Office region of employer

\begin{tabular}{lccc}
\hline & $\begin{array}{c}\mathbf{1 9 9 9} \\
\%\end{array}$ & $\begin{array}{c}\mathbf{2 0 0 0} \\
\%\end{array}$ & $\begin{array}{c}\text { Total no. } \\
\text { of employers }\end{array}$ \\
\hline North East & 11 & 8 & 71976 \\
North West & 9 & 6 & 245697 \\
Yorkshire and the Humber & 8 & 6 & 179373 \\
East Midlands & 7 & 3 & 161272 \\
West Midlands & 9 & 5 & 200189 \\
Eastern & 6 & 5 & 233332 \\
London & 8 & 14 & 382198 \\
South East & 7 & 5 & 366035 \\
South West & 10 & 5 & 215584 \\
TOTAL & & & \\
Base/Coverage: all employers -4001 & & 7 & 2055656 \\
\hline
\end{tabular}

4.3.6 In both studies, staff association and trade union representatives were most likely to be involved in promoting learning or training opportunities than in formally discussing or providing them.

Table 18 Ways in which staff association and trade unions involved

\begin{tabular}{lcc}
\hline & 1999 & $\mathbf{2 0 0 0}$ \\
& $\%$ & $\%$ \\
\hline Promoting learning or training opportunities with employers & 36 & 42 \\
Formally discussing learning or training opportunities with employers & 35 & 38 \\
Directly providing learning or training opportunities with employers & 23 & 21 \\
\hline
\end{tabular}

Base/Coverage: all employers with staff association or trade union representation - 443 
Chapter 5

Provision of Off-the-J ob Training 


\section{$5 \quad$ Provision of Off-the-Job Training}

\section{$5.1 \quad$ Introduction}

5.1.1 In this section we explore:

- the proportion of employers who have provided off-the-job training over the previous 12 months

- the types of employer who were most likely to provide off-the-job training

- the proportion of employees who received off-the-job training

- the amount of off-the-job training provided

- the occupational groups most likely to have received off-the-job training

5.1.2 It was explained to employers that:

“... by off-the-job training, we are including all training away from the immediate work position. It can be given at your premises or elsewhere. It includes all sorts of courses - full or part time; correspondence or distance learning; health and safety training and so on - as long as it is funded or arranged by you".

\subsection{Employers Who Provide Off-the-Job Training}

5.2.1 The survey indicates that two out of five employers (41\%) have provided off-the-job training to at least some of their employees over the previous 12 months. This represents an increase of seven percentage points since the 1999 study when $34 \%$ of employers had provided off-the-job training over the previous 12 months.

This increase is not unexpected but it should be noted that the magnitude of the increase is greater than that indicated by other sources such as the Labour Force Survey.

5.2.2 The following table shows that the proportion of employers providing off-the-job training increases with increasing employer size and that there has been an increase since the 1999 study in the proportion amongst all sizes of employer.

Table 19 Provision of off-the-job training by size of employer

\begin{tabular}{lccc}
\hline & $\mathbf{1 9 9 9}$ & $\mathbf{2 0 0 0}$ & Total no. \\
$\%$ & $\%$ & $\begin{array}{c}\text { of employers } \\
\text { of }\end{array}$ \\
\hline $1-4$ & 25 & 33 & 1480267 \\
$5-24$ & 47 & 54 & 428851 \\
$25-99$ & 72 & 78 & 117187 \\
$100-199$ & 82 & 92 & 17155 \\
$200-499$ & 89 & 96 & 9163 \\
$500+$ & 91 & 98 & 3033 \\
TOTAL & & & \\
\hline Base/Coverage: all & 34 & 41 & 2055656 \\
\hline
\end{tabular}


5.2.3 Employers in the transport, public administration and other services sector (54\%) were most likely to have provided off-the-job training and those in the distribution and consumer services sector least likely to have done so (32\%).

There has been an increase in the proportion of employers providing off-the-job training since the 1999 study in all industry sectors.

Table 20 Provision of off-the-job training by industry sector of employer

\begin{tabular}{lccc}
\hline & $\mathbf{1 9 9 9}$ & $\mathbf{2 0 0 0}$ & $\begin{array}{c}\text { Total no. } \\
\text { of employers }\end{array}$ \\
\hline Manufacturing & $\%$ & $\%$ & 183042 \\
Agriculture, mining, utilities, construction & 30 & 44 & 250929 \\
Distribution \& consumer services & 31 & 35 & 624092 \\
Finance \& business services & 25 & 32 & 559591 \\
Transport, public administration and other services & 38 & 41 & 438002 \\
TOTAL & 42 & 54 & \\
\hline Base/Coverage: all employers - 4001 & 34 & 41 & 2055656 \\
\end{tabular}

Base/Coverage: all employers - 4001

5.2.4 The provision of off-the-job training by employers in the last year was highest in Yorkshire and the Humber (48\%) and lowest in the West Midlands and Eastern regions (37\%).

There has been an increase since the 1999 study in the proportion of employers who have provided off-the-job training over the previous 12 months in all regions except the South West.

Table 21 Provision of off-the-job training by Government Office region of employer

\begin{tabular}{lccc}
\hline & $\begin{array}{c}\mathbf{1 9 9 9} \\
\%\end{array}$ & $\begin{array}{c}\mathbf{2 0 0 0} \\
\%\end{array}$ & $\begin{array}{c}\text { Total no. } \\
\text { of employers }\end{array}$ \\
\hline North East & 34 & 42 & 71976 \\
North West & 34 & 46 & 245697 \\
Yorkshire and the Humber & 37 & 48 & 179373 \\
East Midlands & 42 & 46 & 161272 \\
West Midlands & 31 & 37 & 200189 \\
Eastern & 34 & 37 & 233332 \\
London & 28 & 38 & 382198 \\
South East & 32 & 39 & 366035 \\
South West & 41 & 39 & 215584 \\
& & & \\
TOTAL & 34 & 41 & 2055656 \\
\hline
\end{tabular}

Base/Coverage: all employers - 4001 


\subsection{Proportion of Employees Receiving Off-the-Job Training}

5.3.1 Overall, $26 \%$ of employees had received off-the-job training over the previous 12 months. This represents an increase over the $22 \%$ reported in the 1999 study.

5.3.2 The proportion of employees trained initially increases with increasing establishment size, reaching a peak amongst establishments with 100-199 employees and then decreases as establishments become larger.

There has been an increase since the 1999 study in the proportion of employees trained in all sizes of establishment except the very largest.

Table 22 Proportion of employees receiving off-the-job training by size of employer

\begin{tabular}{lcc}
\hline & $\begin{array}{c}\mathbf{1 9 9 9} \\
\%\end{array}$ & $\begin{array}{c}\mathbf{2 0 0 0} \\
\%\end{array}$ \\
\hline $1-4$ & 16 & 22 \\
$5-24$ & 23 & 27 \\
$25-99$ & 28 & 33 \\
$100-199$ & 25 & 36 \\
$200-499$ & 25 & 35 \\
$500+$ & 20 & 16 \\
& & \\
TOTAL & 22 & 26 \\
\hline
\end{tabular}

Base/Coverage: all employers providing off-the-job training over the previous 12 months -2903

5.3.3 The proportion of employees trained was highest in the transport, public administration and other services sector and lowest in the manufacturing sector.

There has been an increase in the proportion of employees trained since the 1999 study in all industry sectors.

Table 23 Proportion of employees receiving off-the-job training by industry sector of employer

\begin{tabular}{lcc}
\hline & $\mathbf{1 9 9 9}$ & $\mathbf{2 0 0 0}$ \\
& $\%$ & $\%$ \\
\hline Manufacturing & 18 & 22 \\
Agriculture, mining, utilities, construction & 21 & 28 \\
Distribution \& consumer services & 17 & 25 \\
Finance \& business services & 22 & 28 \\
Transport, public administration \& other services & 27 & 29 \\
& & \\
TOTAL & 22 & 26 \\
\hline Base/Coverage: all employers providing off-the-job training over the previous 12 months - 2903
\end{tabular}


5.3.4 There was little difference by region in the proportion of employees who had received offthe-job training over the previous year.

Table 24 Proportion of employees receiving off-the-job training by Government Office region of employer

\begin{tabular}{lcc}
\hline & $\mathbf{1 9 9 9}$ & $\mathbf{2 0 0 0}$ \\
& $\%$ & $\%$ \\
\hline North East & 26 & 26 \\
North West & 21 & 28 \\
Yorkshire and the Humber & 21 & 28 \\
East Midlands & 21 & 26 \\
West Midlands & 17 & 25 \\
Eastern & 20 & 28 \\
London & 21 & 27 \\
South East & 25 & 24 \\
South West & 27 & 26 \\
TOTAL & & \\
\hline
\end{tabular}

Base/Coverage: all employers providing off-the-job training over the previous 12 months -2903

\subsection{Amount of Off-the-Job Training Provided}

5.4.1 Employers were asked to estimate the number of days off-the-job training they had provided per employee trained. When using these figures it should be borne in mind that these figures may be subject to a greater degree of inaccuracy than other non-cost related data in this report.

5.4.2 Over the last 12 months, employees receiving off-the-job training had, on average, received 8.2 days each. This equates to an average of 2.2 days being provided per employee.

The equivalent figures in the 1999 study were 8.6 days per employee trained and 1.9 days per employee.

An explanation of the, at first sight apparently odd, fact that one measure has increased since the 1999 study whilst the second has declined can be found in the way that the per employee figure is calculated. The per employee figure uses (i) the proportion of employees receiving off-the-job training $(0.26)$ and (ii) the number of days of off-the-job training provided per trainee (8.2) as part of the calculation. The reason is that since 1999, the proportion receiving training has increased by a greater margin than the number of days of off-the-job training provided per trainee.

5.4.3 In the following three paragraphs when the average number of days off-the-job training provided is shown, the first table in each paragraph shows the average number of days provided per trainee, and the second the average number per employee, whether trained or not. 
5.4.4 The average number of days training provided by establishments of various sizes is shown in the two tables below.

It can be seen from Table 25 that the average number of days reaches a peak amongst establishments with 100-199 employees and then declines.

Table 25 Average number of training days per employee trained by size of employer

\begin{tabular}{lcc}
\hline & $\mathbf{1 9 9 9}$ & $\mathbf{2 0 0 0}$ \\
\hline $1-4$ & 7.3 & 8.2 \\
$5-24$ & 10.4 & 8.2 \\
$25-99$ & 9.4 & 8.2 \\
$100-199$ & 9.4 & 8.7 \\
$200-499$ & 9.4 & 6.8 \\
$500+$ & 8.6 & 6.5 \\
& & \\
TOTAL & 8.6 & 8.2 \\
\hline Base/Coverage: all employers providing off-the-job training over
\end{tabular}

Base/Coverage: all employers providing off-the-job training over

the previous 12 months - 2903

Table 26 Average number of training days per employee by size of employer

\begin{tabular}{lcc}
\hline & $\mathbf{1 9 9 9}$ & $\mathbf{2 0 0 0}$ \\
\hline $1-4$ & 1.2 & 1.8 \\
$5-24$ & 2.4 & 2.2 \\
$25-99$ & 2.7 & 2.7 \\
$100-199$ & 2.3 & 3.1 \\
$200-499$ & 2.3 & 2.4 \\
$500+$ & 1.7 & 1.1 \\
TOTAL & & \\
\hline
\end{tabular}

Base/Coverage: all employers providing off-the-job training over the previous 12 months -2903 
5.4.5 The average number of training days provided by employers in each industry sector is shown in the next two tables.

It can be seen from Table 27 that trainees in the agriculture, mining, utilities and construction and in the finance and business services sectors had received the most training.

Table 27 Average number of training days per employee trained by industry sector of employer

\begin{tabular}{lcc}
\hline & $\mathbf{1 9 9 9}$ & $\mathbf{2 0 0 0}$ \\
\hline Manufacturing & 11.4 & 8.4 \\
Agriculture, mining, utilities, construction & 8.9 & 10.4 \\
Distribution \& consumer services & 9.6 & 6.1 \\
Finance \& business services & 6.5 & 9.2 \\
Transport, public admin \& other services & 9.3 & 8.1 \\
TOTAL & & \\
\hline
\end{tabular}

Base/Coverage : all employers providing off-the-job training over the previous 12 months 2903

Table 28 Average number of training days per employee by industry sector of employer

\begin{tabular}{lcc}
\hline & $\mathbf{1 9 9 9}$ & $\mathbf{2 0 0 0}$ \\
\hline Manufacturing & 2.0 & 1.8 \\
Agriculture, mining, utilities, construction & 1.9 & 2.3 \\
Distribution \& consumer services & 1.6 & 2.0 \\
Finance \& business services & 1.4 & 2.4 \\
Transport, public admin \& other services & 2.6 & 1.9 \\
TOTAL & 1.9 & 2.2 \\
\hline
\end{tabular}

Base/Coverage: all employers providing off-the-job training over the previous 12 months 2903 
5.4.6 As shown in Table 29, trainees in the North East region had received the highest number of days training in the last year. Trainees in the Eastern, South East and North West regions had received the least.

Table 29 Average number of training days per employee trained by Government Office region of employer

\begin{tabular}{lcc}
\hline & $\mathbf{1 9 9 9}$ & $\mathbf{2 0 0 0}$ \\
\hline North East & 10.0 & 11.9 \\
North West & 9.2 & 6.3 \\
Yorkshire and the Humber & 8.0 & 8.3 \\
East Midlands & 9.7 & 8.2 \\
West Midlands & 9.7 & 9.1 \\
Eastern & 5.2 & 6.0 \\
London & 9.0 & 10.0 \\
South East & 7.7 & 6.3 \\
South West & 10.3 & 10.7 \\
& & \\
TOTAL & 8.6 & 8.2 \\
\hline Base/Coverage: all employers providing off-the-job training over the previous 12 \\
months - 2903
\end{tabular}

Table 30 Average number of training days per employee by Government Office region of employer

\begin{tabular}{lcc}
\hline & $\mathbf{1 9 9 9}$ & $\mathbf{2 0 0 0}$ \\
\hline North East & 2.6 & 3.1 \\
North West & 2.0 & 1.7 \\
Yorkshire and the Humber & 1.7 & 2.3 \\
East Midlands & 2.0 & 2.2 \\
West Midlands & 1.7 & 2.2 \\
Eastern & 1.0 & 1.7 \\
London & 1.9 & 2.7 \\
South East & 1.9 & 1.5 \\
South West & 2.8 & 2.8 \\
TOTAL & \multicolumn{2}{c}{} \\
Base/Coverage: all employers providing off-the-job training over the previous 12 \\
months - 2903
\end{tabular}




\subsection{Occupations Receiving Off-the-Job Training}

5.5.1 The table below shows the proportion of employers employing each occupational group who had provided employees in that occupational group with off-the-job training in the last 12 months.

Technical and scientific staff are most likely to have received off-the-job training : other manual staff the least likely.

Since the 1999 study there has been a noticeable increase in training activity amongst the technical and scientific and professional occupational groups.

\section{Fig $4 \quad$ Occupations receiving off-the-job training}

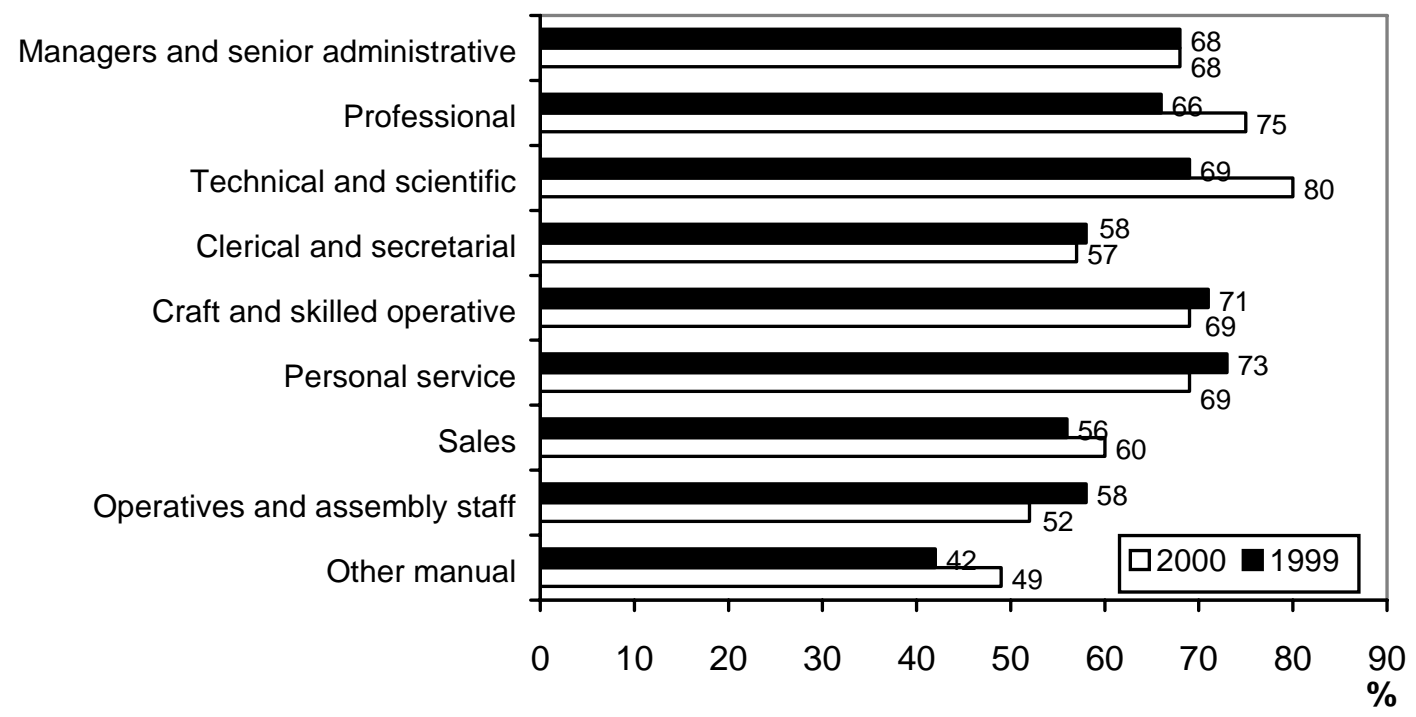

Base/Coverage: all employers employing each occupation 
Chapter 6

Management and Delivery of Off-the-J ob Training 


\section{$6 \quad$ Management and Delivery of Off-the-Job Training}

\subsection{Introduction}

6.1.1 This section examines employers' approach to off-the-job training in a number of areas:

- The existence and format of business, training and human resource plans and budgets - either as written statements or less formally

- The allocation of staff and resources towards the training of employees

- The types of off-the-job training which had been provided over the last year

- The number of employers who used off-the-job training to provide formal qualifications for their employees and the types of formal qualification towards which employees were training

- The location of the off-the-job training provided

- The methods of off-the-job training used in the last 12 months

\subsection{Existence of Business, Training and Human Resource Plans and Budgets}

6.2.1 The proportion of employers having a business plan, a training plan, a training budget and a human resources plan is shown in the table below.

It can be seen that three out of five (60\%) had a business plan, two out of five (39\%) a training plan, over a quarter (27\%) a training budget and just under a quarter (24\%) a human resources plan.

The existence of all four planning tools has increased since the 1999 study.

Fig 5

Existence of plans and budgets

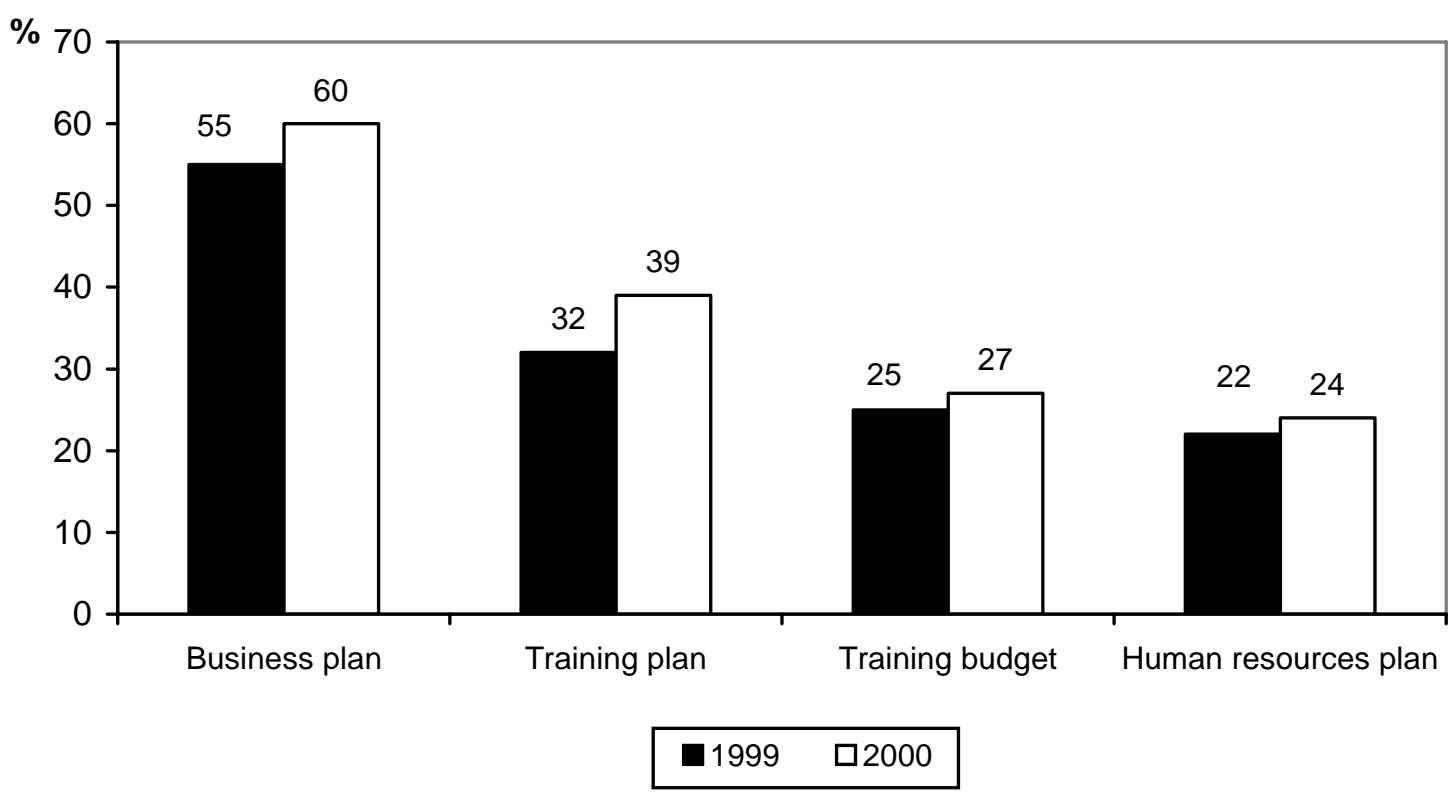

Base/Coverage: all employers - 4001 
6.2.2 As the following table illustrates, the existence of plans and budgets increases with increasing size of employer.

Table 31 Existence of plans and budgets by size of employer

\begin{tabular}{|c|c|c|c|c|c|c|c|c|}
\hline & \multicolumn{2}{|c|}{ Business plan } & \multicolumn{2}{|c|}{ Training plan } & \multicolumn{2}{|c|}{ Training budget } & \multicolumn{2}{|c|}{$\begin{array}{l}\text { Human resource } \\
\text { plan }\end{array}$} \\
\hline & $\begin{array}{c}1999 \\
\%\end{array}$ & $\begin{array}{c}2000 \\
\% \\
\end{array}$ & $\begin{array}{c}1999 \\
\%\end{array}$ & $\begin{array}{c}2000 \\
\% \\
\end{array}$ & $\begin{array}{c}1999 \\
\%\end{array}$ & $\begin{array}{c}2000 \\
\% \\
\end{array}$ & $\begin{array}{c}1999 \\
\% \\
\end{array}$ & $\begin{array}{c}2000 \\
\% \\
\end{array}$ \\
\hline $1-4$ & 50 & 57 & 22 & 31 & 16 & 18 & 15 & 18 \\
\hline $5-24$ & 63 & 66 & 52 & 54 & 38 & 42 & 32 & 36 \\
\hline $25-99$ & 75 & 79 & 69 & 69 & 62 & 65 & 51 & 50 \\
\hline $100-199$ & 88 & 89 & 80 & 79 & 79 & 82 & 65 & 65 \\
\hline $200-499$ & 92 & 93 & 89 & 83 & 88 & 88 & 76 & 73 \\
\hline $500+$ & 92 & 94 & 89 & 88 & 94 & 93 & 83 & 84 \\
\hline TOTAL & 55 & 60 & 32 & 39 & 25 & 27 & 22 & 24 \\
\hline
\end{tabular}

6.2.3 Employers in the transport, public administration and other services and in the finance and business services sectors were most likely to have plans and budgets.

Table 32 Existence of plans and budgets by industry sector of employer

\begin{tabular}{|c|c|c|c|c|c|c|c|c|}
\hline & \multicolumn{2}{|c|}{ Business plan } & \multicolumn{2}{|c|}{ Training plan } & \multicolumn{2}{|c|}{$\begin{array}{c}\text { Training } \\
\text { budget }\end{array}$} & \multicolumn{2}{|c|}{$\begin{array}{c}\text { Human } \\
\text { resource plan }\end{array}$} \\
\hline & 1999 & 2000 & 1999 & 2000 & 1999 & 2000 & 1999 & 2000 \\
\hline & $\%$ & $\%$ & $\%$ & $\%$ & $\%$ & $\%$ & $\%$ & $\%$ \\
\hline Manufacturing & 57 & 61 & 28 & 35 & 17 & 23 & 16 & 24 \\
\hline Agriculture, mining, utilities, construction & 43 & 47 & 18 & 21 & 12 & 18 & 8 & 10 \\
\hline Distribution \& consumer services & 48 & 54 & 27 & 34 & 17 & 18 & 17 & 21 \\
\hline Finance \& business services & 62 & 74 & 35 & 43 & 26 & 27 & 26 & 28 \\
\hline Transport, public admin \& other services & 60 & 60 & 46 & 52 & 44 & 45 & 31 & 31 \\
\hline TOTAL & 55 & 60 & 32 & 39 & 25 & 27 & 22 & 24 \\
\hline
\end{tabular}


6.2.4 The existence of plans and budgets varied between regions as shown in the table below.

Table 33 Existence of plans and budgets by Government Office region of employer

\begin{tabular}{|c|c|c|c|c|c|c|c|c|}
\hline & \multicolumn{2}{|c|}{ Business plan } & \multicolumn{2}{|c|}{ Training plan } & \multicolumn{2}{|c|}{ Training budget } & \multicolumn{2}{|c|}{$\begin{array}{c}\text { Human } \\
\text { resource plan }\end{array}$} \\
\hline & 1999 & 2000 & 1999 & 2000 & 1999 & 2000 & 1999 & 2000 \\
\hline & $\%$ & $\%$ & $\%$ & $\%$ & $\%$ & $\%$ & $\%$ & $\%$ \\
\hline North East & 50 & 54 & 31 & 45 & 24 & 31 & 21 & 22 \\
\hline North West & 55 & 63 & 35 & 36 & 27 & 27 & 30 & 24 \\
\hline Yorkshire and the Humber & 55 & 65 & 36 & 50 & 23 & 32 & 17 & 29 \\
\hline East Midlands & 57 & 67 & 34 & 50 & 30 & 32 & 13 & 30 \\
\hline West Midlands & 55 & 53 & 29 & 30 & 25 & 19 & 19 & 20 \\
\hline Eastern & 57 & 59 & 33 & 38 & 28 & 29 & 22 & 18 \\
\hline London & 57 & 59 & 29 & 42 & 19 & 23 & 21 & 26 \\
\hline South East & 50 & 59 & 31 & 32 & 24 & 23 & 23 & 20 \\
\hline South West & 56 & 63 & 39 & 36 & 32 & 32 & 25 & 28 \\
\hline TOTAL & 55 & 60 & 32 & 39 & 25 & 27 & 22 & 24 \\
\hline
\end{tabular}

Base/Coverage : all employers - 4001 


\subsection{Form in Which Planning Tools Exist}

6.3.1 For each planning tool in place, employers were asked whether or not it existed as a formal written statement or as something less formal. The following table shows that in the majority of cases, planning tools existed as formal written statements.

In the case of business plans and training plans there has been a small increase since the 1999 study in the proportion of employers using formal written statements.

Fig 6

Form of plans and budgets

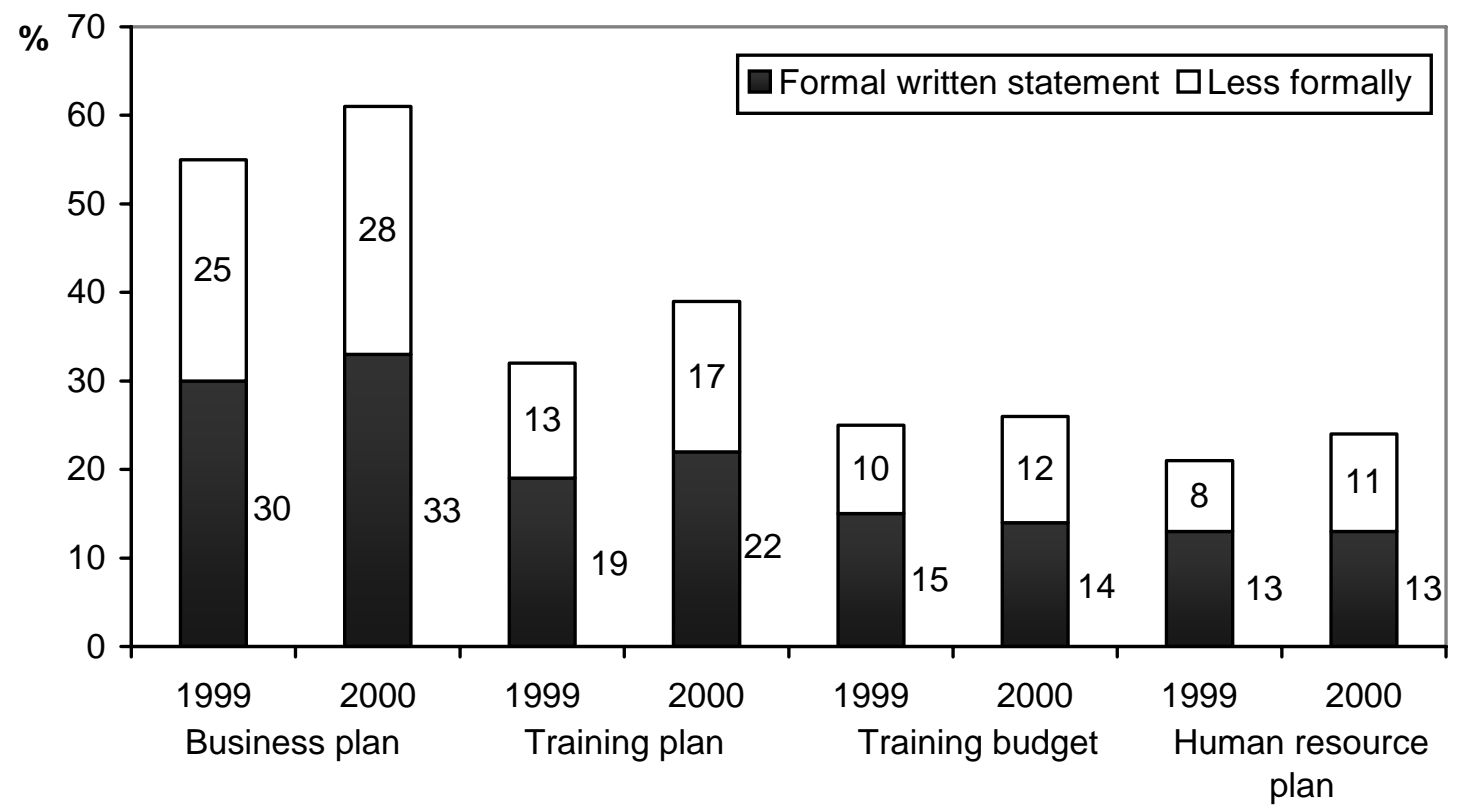

Base: all employers - 4001

Coverage: all employers who have the planning or budgeting tool in place 


\subsection{Resources for Off-the-Job Training}

6.4.1 Employers who had provided off-the-job training in the last 12 months were asked about the existence and commitment of resources for training within their organisation (not just at the establishment sampled). Specifically:

- whether the organisation had someone at senior management level responsible for training

- whether the organisation had a separate training facility such as a training school or centre

- whether the organisation had members of staff to design and teach training courses

6.4.2 Over two-thirds (71\%) of the employers who had provided off-the-job training in the last 12 months had a member of senior management with responsibility for training within their organisation.

This compares with the figure of $67 \%$ reported in the 1999 study.

6.4.3 Staff to design and teach training courses existed in a third (32\%) of organisations providing off-the-job training and a separate training facility in about a quarter $(23 \%)$ of organisations.

The equivalent figures in the 1999 study were $30 \%$ and $23 \%$.

6.4.4 On average, in both years of the study, those employing staff to design and teach training courses employed 9 such people within their organisation.

6.4.5 As the following table indicates, the allocation of staff and resources to training within the organisation increases with increasing size of employer.

Table 34 Allocation of staff and resources for training by size of employer

\begin{tabular}{|c|c|c|c|c|c|c|}
\hline & \multicolumn{2}{|c|}{ Senior management } & \multicolumn{2}{|c|}{ Training staff } & \multicolumn{2}{|c|}{ Training facility } \\
\hline & 1999 & 2000 & 1999 & 2000 & 1999 & 2000 \\
\hline & $\%$ & $\%$ & $\%$ & $\%$ & $\%$ & $\%$ \\
\hline$\overline{1-4}$ & 56 & 66 & 23 & 28 & 16 & 19 \\
\hline $5-24$ & 77 & 76 & 31 & 31 & 28 & 25 \\
\hline $25-99$ & 80 & 81 & 42 & 46 & 33 & 35 \\
\hline $100-199$ & 82 & 83 & 51 & 57 & 43 & 41 \\
\hline $200-499$ & 83 & 84 & 68 & 66 & 52 & 49 \\
\hline $500+$ & 91 & 92 & 84 & 86 & 68 & 64 \\
\hline TOTAL & 67 & 71 & 30 & 32 & 23 & 23 \\
\hline
\end{tabular}


6.4.6 Employers in the transport, public administration and other services sector were the most likely to dedicate staff and resources within the organisation to off-the-job training.

Table 35 Allocation of staff and resources for training by industry sector of employer

\begin{tabular}{|c|c|c|c|c|c|c|}
\hline & \multicolumn{2}{|c|}{$\begin{array}{c}\text { Senior } \\
\text { management }\end{array}$} & \multicolumn{2}{|c|}{ Training staff } & \multicolumn{2}{|c|}{ Training facility } \\
\hline & 1999 & 2000 & 1999 & 2000 & 1999 & 2000 \\
\hline & $\%$ & $\%$ & $\%$ & $\%$ & $\%$ & $\%$ \\
\hline Manufacturing & 71 & 68 & 15 & 16 & 11 & 8 \\
\hline Agriculture, mining, utilities, construction & 46 & 69 & 6 & 7 & 9 & 7 \\
\hline Distribution \& consumer services & 70 & 69 & 37 & 25 & 34 & 26 \\
\hline Finance \& business services & 56 & 70 & 25 & 30 & 16 & 22 \\
\hline Transport, public admin \& other services & 82 & 75 & 43 & 55 & 31 & 34 \\
\hline TOTAL & 67 & 71 & 30 & 32 & 23 & 23 \\
\hline
\end{tabular}

Base/Coverage: all employers providing off-the-job training in the last 12 months - 2903

6.4.7 The proportion of employers in each region having someone at senior management level within the organisation responsible for training, training staff to design and teach courses and a separate training facility is shown below.

Table 36 Allocation of staff and resources for training by Government Office region of employer

\begin{tabular}{lcc|cc|cc} 
& \multicolumn{2}{c|}{ Senior } & \multicolumn{2}{c|}{ Training staff } & \multicolumn{2}{c}{ Training facility } \\
& 1999 & 2000 & 1999 & 2000 & 1999 & 2000 \\
& $\%$ & $\%$ & $\%$ & $\%$ & $\%$ & $\%$ \\
\hline North East & 71 & 72 & 41 & 41 & 36 & 36 \\
North West & 71 & 73 & 25 & 29 & 22 & 25 \\
Yorkshire and the Humber & 73 & 83 & 20 & 32 & 13 & 21 \\
East Midlands & 77 & 72 & 39 & 13 & 25 & 14 \\
West Midlands & 64 & 59 & 27 & 37 & 23 & 16 \\
Eastern & 60 & 70 & 30 & 29 & 19 & 21 \\
London & 52 & 76 & 30 & 36 & 24 & 26 \\
South East & 67 & 61 & 33 & 36 & 26 & 27 \\
South West & 74 & 73 & 28 & 35 & 26 & 25 \\
TOTAL & 67 & 71 & 30 & 32 & 23 & 23 \\
\hline
\end{tabular}

Base/Coverage: all employers providing off-the-job training in the last 12 months - 2903 


\subsection{Types of Off-the-Job Training Provided}

6.5.1 Employers who had provided off-the-job training over the past 12 months were read a list of possible types of training and asked which ones they had provided over this period.

As shown in the table below, job specific training and health and safety training were the types that had been provided by most employers over the previous 12 months.

There has been an increase since the 1999 study in the proportion of employers providing each type of training.

Fig $7 \quad$ Types of off-the-job training provided at the location in the last 12 months

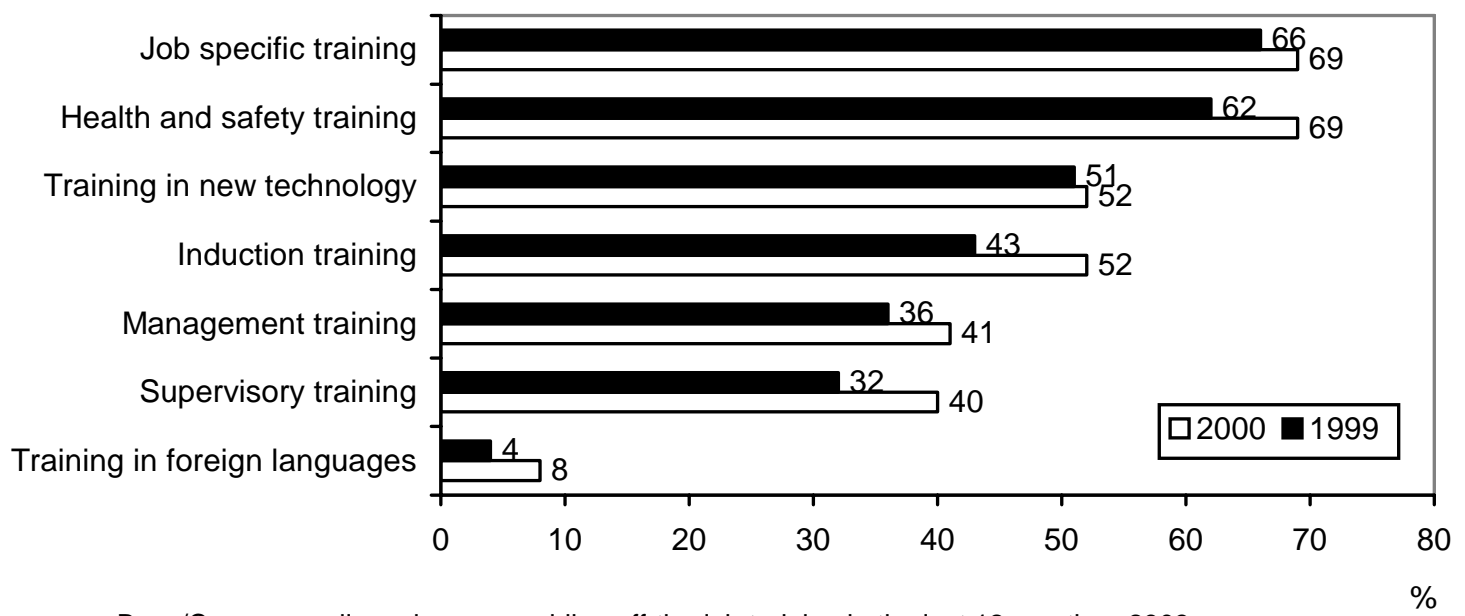

6.5.2 The provision of all types of training generally increases with increasing employer size.

Table 37 Types of off-the-job training provided by size of employer

\begin{tabular}{|c|c|c|c|c|c|c|c|}
\hline & $\begin{array}{l}\text { Total } \\
\%\end{array}$ & $\begin{array}{c}1-4 \\
\%\end{array}$ & $\begin{array}{c}5-24 \\
\%\end{array}$ & $\begin{array}{c}25-99 \\
\%\end{array}$ & $\begin{array}{c}100- \\
199 \\
\%\end{array}$ & $\begin{array}{c}200- \\
499 \\
\%\end{array}$ & $\begin{array}{c}500+ \\
\%\end{array}$ \\
\hline Job specific training & 69 & 61 & 75 & 84 & 88 & 94 & 95 \\
\hline Health and safety training & 69 & 61 & 75 & 88 & 94 & 95 & 95 \\
\hline Training in new technology & 52 & 46 & 56 & 66 & 78 & 87 & 93 \\
\hline Induction training & 52 & 39 & 64 & 79 & 88 & 92 & 94 \\
\hline Management training & 41 & 33 & 44 & 61 & 73 & 87 & 93 \\
\hline Supervisory training & 40 & 33 & 42 & 59 & 70 & 83 & 92 \\
\hline Training in foreign languages & 8 & 11 & 4 & 6 & 13 & 25 & 32 \\
\hline $\begin{array}{l}\text { Total no. of employers providing off-the-job } \\
\text { training }\end{array}$ & 833324 & 482758 & 231975 & 91005 & 15858 & 8765 & 2964 \\
\hline
\end{tabular}


6.5.3 The table below shows the types of training provided in the last year by industry sector of employer.

Table 38 Types of off-the-job training provided by industry sector of employer

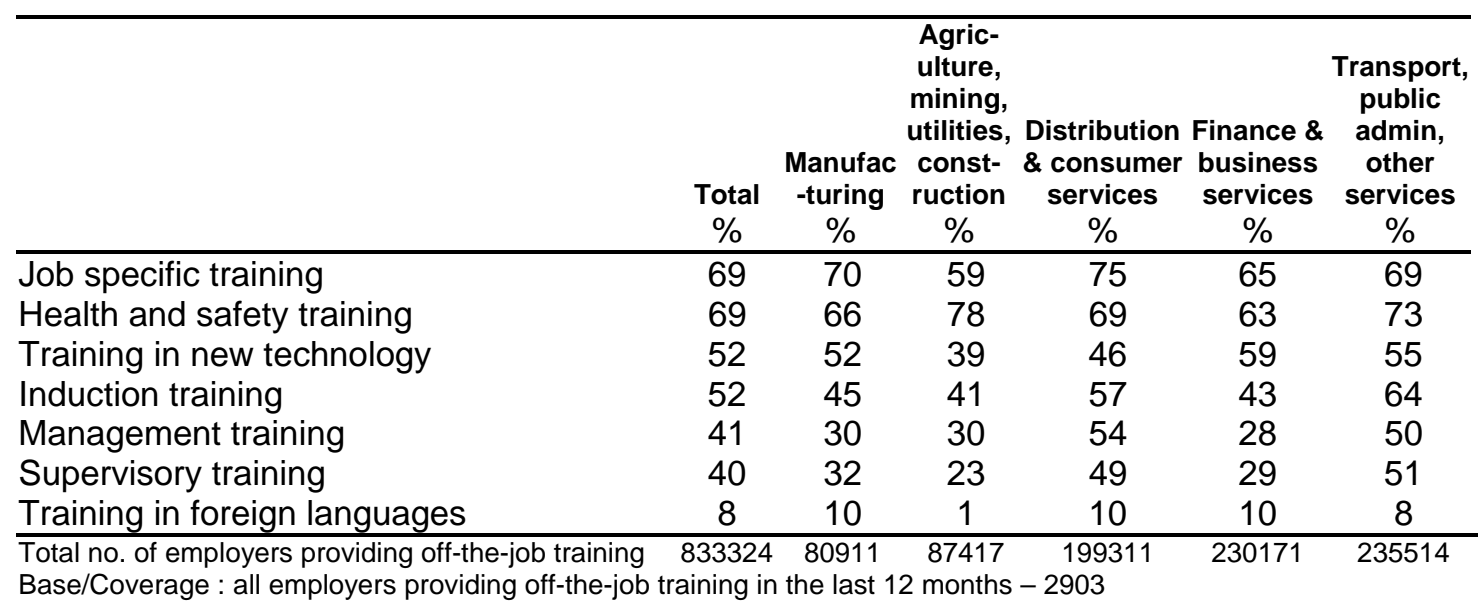

\subsection{Off-the-Job Training Leading to Formal Qualifications}

6.6.1 Of those employers who provided off-the-job training, $46 \%$ reported that some of this training was leading to formal qualifications. The equivalent figure in the 1999 study was $43 \%$.

6.6.2 As shown in the table below, a higher proportion of larger employers offered some training which was leading to formal qualifications.

Table 39 Employers offering some off-the-job training leading to formal qualifications by size of employer

\begin{tabular}{lccc}
\hline & $\mathbf{1 9 9 9}$ & $\mathbf{2 0 0 0}$ & $\begin{array}{c}\text { Total no. of } \\
\text { employers } \\
\text { providing } \\
\text { off-the-job } \\
\text { training }\end{array}$ \\
\hline $1-4$ & $\%$ & $\%$ & $\begin{array}{c}\text { \% } \\
5-24\end{array}$ \\
$25-99$ & 44 & 39 & 482758 \\
$100-199$ & 57 & 51 & 231975 \\
$200-499$ & 67 & 73 & 91005 \\
$500+$ & 85 & 82 & 87658 \\
TOTAL & 90 & 90 & 2964 \\
\hline
\end{tabular}

Base/Coverage : all employers providing off-the-job training in the last 12 months 2903 
6.6.3 The provision of training leading to formal qualifications varied by industry sector as shown below.

Table 40 Employers offering some off-the-job training leading to formal qualifications by industry sector of employer

\begin{tabular}{|c|c|c|c|}
\hline & $\begin{array}{c}1999 \\
\%\end{array}$ & 2000 & $\begin{array}{c}\text { Total no. of } \\
\text { employers } \\
\text { providing } \\
\text { off-the-job } \\
\text { training }\end{array}$ \\
\hline Manufacturing & 50 & 39 & 80911 \\
\hline Agriculture, mining, utilities, construction & 48 & 60 & 87417 \\
\hline Distribution \& consumer services & 42 & 45 & 199311 \\
\hline Finance \& business services & 38 & 40 & 230171 \\
\hline Transport, public administration \& other services & 46 & 51 & 235514 \\
\hline TOTAL & 43 & 46 & 833324 \\
\hline
\end{tabular}

6.6.4 The proportion of employers in each region providing off-the-job training who had provided some training leading to formal qualifications is shown below.

Table 41 Employers offering some off-the-job training leading to formal qualifications by Government Office region of employer

\begin{tabular}{lccc}
\hline & $\mathbf{1 9 9 9}$ & $\mathbf{2 0 0 0}$ & $\begin{array}{c}\text { Total no. of } \\
\text { employers } \\
\text { providing } \\
\text { Off-the-job } \\
\text { training }\end{array}$ \\
\hline North East & $\%$ & $\%$ & 29935 \\
North West & 44 & 55 & 112247 \\
Yorkshire and the Humber & 50 & 44 & 86396 \\
East Midlands & 56 & 41 & 74455 \\
West Midlands & 51 & 47 & 73250 \\
Eastern & 45 & 58 & 87307 \\
London & 43 & 52 & 144659 \\
South East & 25 & 45 & 140957 \\
South West & 39 & 39 & 84117 \\
TOTAL & 47 & 50 & 833324 \\
\hline
\end{tabular}

Base/Coverage: all employers providing off-the-job training in the last 12 months - 2903 


\subsection{Types of Formal Qualification}

6.7.1 Employers who stated that some of the off-the-job training they provided was leading to formal qualifications were asked which, if any, of the following qualifications it was leading to:

- NVQs/SVQs

- Other nationally recognised qualifications, eg RSA, BTEC, City and Guilds

- Qualifications specific to the company

- Higher qualifications such as degrees

6.7.2 Other nationally recognised qualifications and NVQs/SVQs were the types of qualification that some off-the-job training was most commonly leading to (48\% and $46 \%$ of those providing training leading to qualifications respectively).

Since the 1999 study there has been an increase in the extent to which some off-the-job training is leading to company specific qualifications and to higher level qualifications.

Table 42 Types of formal qualification to which off-the-job training leading

\begin{tabular}{lcc}
\hline & 1999 & $\mathbf{2 0 0 0}$ \\
& $\%$ & 48 \\
\hline Other nationally recognised qualifications & 48 & 46 \\
NVQS/SVQs & 45 & 46 \\
Qualifications specific to company & 25 & 32 \\
Higher qualifications such as degrees & 17 & 24 \\
\hline
\end{tabular}

Base/Coverage: all employers providing off-the-job training in the last 12 months

leading to formal qualifications -2013 


\subsection{Location of Off-the-Job Training}

6.8.1 The most common location for providing off-the-job training was at a private training centre (66\% of employers providing off-the-job training), followed by at an FE college (32\%), at the employer's establishment (31\%) and finally at a company training centre (22\%).

Since the 1999 study there has been an increase in training taking place at a private training centre and at the establishment interviewed.

Table 43 Location of off-the-job training

\begin{tabular}{lcc}
\hline & $\mathbf{1 9 9 9}$ & $\mathbf{2 0 0 0}$ \\
& $\%$ & $\%$ \\
\hline Private training centre & 55 & 66 \\
FE College & 31 & 32 \\
Establishment interviewed & 22 & 31 \\
Company training centre & 19 & 22 \\
Elsewhere & 10 & 17 \\
\hline Base/Coverage: all employers providing off-the-job training in the last 12 months - \\
2903
\end{tabular}

6.8.2 The likelihood of using each location increased with increasing size of employer. It can be seen that the variation by establishment size is much greater for some types of location than for others.

Table 44 Location of off-the-job training by size of employer

\begin{tabular}{|c|c|c|c|c|c|c|c|}
\hline & $\begin{array}{c}\text { Total } \\
\% \\
\end{array}$ & $\begin{array}{c}1-4 \\
\% \\
\end{array}$ & $\begin{array}{c}5-24 \\
\% \\
\end{array}$ & $\begin{array}{c}25-99 \\
\%\end{array}$ & $\begin{array}{c}\text { 100-199 } \\
\%\end{array}$ & $\begin{array}{c}200-499 \\
\% \\
\end{array}$ & $\begin{array}{c}500+ \\
\%\end{array}$ \\
\hline $\begin{array}{l}\text { At a private training } \\
\text { Centre }\end{array}$ & 66 & 67 & 63 & 66 & 74 & 80 & 80 \\
\hline At an FE college & 32 & 25 & 36 & 45 & 58 & 67 & 73 \\
\hline $\begin{array}{l}\text { At establishment } \\
\text { Interviewed }\end{array}$ & 31 & 19 & 38 & 59 & 72 & 84 & 87 \\
\hline $\begin{array}{l}\text { At company training } \\
\text { Centre }\end{array}$ & 22 & 18 & 23 & 35 & 45 & 53 & 66 \\
\hline Elsewhere & 17 & 21 & 12 & 11 & 12 & 10 & 16 \\
\hline $\begin{array}{l}\text { Total no. of employers } \\
\text { providing off-the-job training }\end{array}$ & 833324 & 482758 & 231975 & 91005 & 15858 & 8765 & 2964 \\
\hline
\end{tabular}


6.8.3 The most commonly used locations varied according to the industry sector of the employer. For example:

- A private training centre was most likely to be used by employers in the manufacturing sector

- An FE college was most likely to be used by employers in the agriculture, mining, utilities and construction sector

- The employer's establishment and a company training centre were most likely to be used by employers in the transport, public administration and other services sector

Table 45 Location of off-the-job training by industry sector of employer

\begin{tabular}{|c|c|c|c|c|c|c|}
\hline & $\begin{array}{c}\text { Total } \\
\%\end{array}$ & $\begin{array}{c}\text { Manufac } \\
\text {-turing } \\
\%\end{array}$ & $\begin{array}{c}\text { Agric- } \\
\text { ulture, } \\
\text { mining, } \\
\text { utilities, } \\
\text { const- } \\
\text { ruction } \\
\%\end{array}$ & $\begin{array}{c}\text { Distribution } \\
\& \text { consumer } \\
\text { services } \\
\%\end{array}$ & $\begin{array}{c}\text { Finance \& } \\
\text { business } \\
\text { services } \\
\%\end{array}$ & $\begin{array}{c}\text { Transport, } \\
\text { public } \\
\text { admin, } \\
\text { other } \\
\text { services } \\
\%\end{array}$ \\
\hline At a private training centre & 66 & 78 & 49 & 66 & 64 & 70 \\
\hline At an FE college & 32 & 43 & 55 & 19 & 28 & 33 \\
\hline At establishment interviewed & 31 & 40 & 18 & 28 & 22 & 43 \\
\hline At company training centre & 22 & 14 & 9 & 21 & 19 & 35 \\
\hline Elsewhere & 17 & 14 & 8 & 24 & 18 & 15 \\
\hline Total no. of employers providing off-th & & 30911 & 7417 & 199311 & 230171 & 235514 \\
\hline
\end{tabular}

\subsection{Satisfaction with Quality of Training Provided by Private Training Providers and FE Colleges}

6.9.1 Overall, nine out of ten (89\%) of employers who had used a private training provider or FE college were satisfied with the quality of the training provided. This figure is very similar to the $90 \%$ reported in the 1999 study.

Table 46 Satisfaction with quality of training provided by private training providers and FE colleges

\begin{tabular}{lcc}
\hline & $\mathbf{1 9 9 9}$ & $\mathbf{2 0 0 0}$ \\
& $\%$ & $\%$ \\
\hline Very satisfied & 53 & 53 \\
Fairly satisfied & 37 & 36 \\
Not very satisfied & 3 & 4 \\
Not at all satisfied & 2 & 2 \\
Not stated & 6 & 5 \\
\hline
\end{tabular}

Base/Coverage: all employers who had used private training providers or FE Colleges - 2500

6.9.2 Levels of satisfaction did not vary widely by size, industry sector or region of employer, with almost all employers being at least fairly satisfied. 


\subsection{Methods of Providing Off-the-Job Training}

6.10.1 Since the 1999 study there has been an increase in all methods of providing off-the-job training, most noticeably in encouraging employees to keep up-to-date on the types of work they do without taking part in a taught course.

\section{Table 47 Methods of providing off-the-job training}

\begin{tabular}{|c|c|c|}
\hline & $\begin{array}{c}1999 \\
\%\end{array}$ & $\begin{array}{c}2000 \\
\%\end{array}$ \\
\hline $\begin{array}{l}\text { Education and training courses intended to lead } \\
\text { to a qualification }\end{array}$ & 45 & 50 \\
\hline $\begin{array}{l}\text { Other taught courses designed to help } \\
\text { employees develop skills }\end{array}$ & 64 & 68 \\
\hline $\begin{array}{l}\text { Learning involving employees studying on their } \\
\text { own from a package of materials* }\end{array}$ & 32 & 41 \\
\hline $\begin{array}{l}\text { Encourage employees to keep up-to-date on the } \\
\text { types of work they do without taking part in a } \\
\text { taught course }\end{array}$ & 58 & 84 \\
\hline \multicolumn{3}{|c|}{$\begin{array}{l}\text { Base/Coverage: all employers providing off-the-job training in the past } 12 \text { months - } \\
2903\end{array}$} \\
\hline
\end{tabular}


6.10.2 All methods of providing off-the-job training were more likely to have been provided by larger employers than by their smaller counterparts.

Table 48 Methods of providing off-the-job training by size of employer

\begin{tabular}{|c|c|c|c|c|c|c|c|}
\hline & $\begin{array}{c}\text { Total } \\
\%\end{array}$ & $\begin{array}{c}1-4 \\
\%\end{array}$ & $\begin{array}{c}5-24 \\
\%\end{array}$ & $\begin{array}{c}25-99 \\
\%\end{array}$ & $\begin{array}{c}100-199 \\
\%\end{array}$ & $\begin{array}{c}200-499 \\
\%\end{array}$ & $\begin{array}{c}500+ \\
\%\end{array}$ \\
\hline $\begin{array}{l}\text { Education and training } \\
\text { courses intended to } \\
\text { lead to a qualification }\end{array}$ & 50 & 41 & 57 & 68 & 80 & 85 & 92 \\
\hline $\begin{array}{l}\text { Other taught courses } \\
\text { designed to help } \\
\text { employees develop } \\
\text { skills }\end{array}$ & 68 & 63 & 70 & 81 & 89 & 95 & 98 \\
\hline $\begin{array}{l}\text { Learning involving } \\
\text { employees studying } \\
\text { on their own from a } \\
\text { package of materials }\end{array}$ & 41 & 37 & 43 & 50 & 61 & 71 & 81 \\
\hline $\begin{array}{l}\text { Encourage employees } \\
\text { to keep up-to-date on } \\
\text { the types of work they } \\
\text { do without taking part } \\
\text { in a taught course }\end{array}$ & 84 & 84 & 84 & 81 & 85 & 85 & 92 \\
\hline 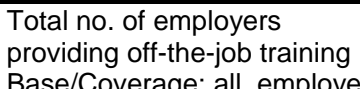 & 833324 & 482758 & 231975 & 91005 & 15858 & 8765 & 2964 \\
\hline
\end{tabular}

6.10.3 Results by industry sector are shown below:

Table 49 Methods of providing off-the-job training by industry sector of employer

\begin{tabular}{|c|c|c|c|c|c|c|}
\hline & $\begin{array}{c}\text { Total } \\
\%\end{array}$ & $\begin{array}{c}\text { Manufac } \\
\text {-turing } \\
\%\end{array}$ & $\begin{array}{c}\text { Agric- } \\
\text { ulture, } \\
\text { mining, } \\
\text { utilities, } \\
\text { const- } \\
\text { ruction } \\
\% \\
\%\end{array}$ & $\begin{array}{l}\text { Distribution } \\
\text { \& consumer } \\
\text { services } \\
\% \\
\end{array}$ & $\begin{array}{l}\text { Finance \& } \\
r \text { business } \\
\text { services } \\
\%\end{array}$ & $\begin{array}{c}\text { Transport, } \\
\text { public } \\
\text { admin, } \\
\text { other } \\
\text { services } \\
\% \\
\end{array}$ \\
\hline $\begin{array}{l}\text { Education and training courses intended } \\
\text { to lead to a qualification }\end{array}$ & 50 & 52 & 65 & 50 & 45 & 49 \\
\hline $\begin{array}{l}\text { Other taught courses designed to help } \\
\text { employees develop skills }\end{array}$ & 68 & 63 & 64 & 67 & 69 & 70 \\
\hline $\begin{array}{l}\text { Learning involving employees studying on } \\
\text { their own from a package of materials }\end{array}$ & 41 & 27 & 27 & 44 & 49 & 42 \\
\hline $\begin{array}{l}\text { Encourage employees to keep up-to-date } \\
\text { on the types of work they do without } \\
\text { taking part in a taught course }\end{array}$ & 84 & 78 & 74 & 86 & 79 & 92 \\
\hline $\begin{array}{l}\text { Total no. of employers providing off-the-job training } \\
\text { Base/Coverage: all employers providing off-the-job }\end{array}$ & 833324 & 0911 & 87417 & $\begin{array}{l}199311 \\
2903\end{array}$ & 230171 & 2 \\
\hline
\end{tabular}


Chapter 7

Provision of On-the-J ob Training 


\section{$7 \quad$ Provision of On-the-Job Training}

7.1.1 Employers were asked whether or not they had carried out any on-the-job training over the past 12 months. Two-thirds (66\%) of employers had done so. The equivalent figure in the 1999 study was $58 \%$.

This increase is not unexpected but it should be noted that the magnitude of the increase is greater than that indicated by other sources such as the Labour Force Survey.

7.1.2 Provision of on-the-job training, generally speaking, became more common with increasing size of employer, and was almost universal amongst employers with 100 or more employees.

Table 50 Provision of on-the-job training by size of employer

\begin{tabular}{lccc}
\hline & $\mathbf{1 9 9 9}$ & $\mathbf{2 0 0 0}$ & Total no. \\
& $\%$ & $\%$ & of employers \\
\hline $1-4$ & 49 & 59 & 1480267 \\
$5-24$ & 77 & 81 & 428851 \\
$25-99$ & 85 & 89 & 117187 \\
$100-199$ & 88 & 94 & 17155 \\
$200-499$ & 94 & 93 & 9163 \\
$500+$ & 94 & 92 & 3033 \\
TOTAL & 58 & 66 & 2055656 \\
\hline Base/Coverage: all employers -4001 & \multicolumn{3}{l}{}
\end{tabular}

7.1.3 Employers in the transport, public administration and other services and in the distribution and consumer services sectors were most likely to have provided on-the-job training and those in the agriculture, mining, utilities and construction sector least likely to have done so.

Table 51 Provision of on-the-job training by industry sector of employer

\begin{tabular}{lccc}
\hline & $\mathbf{1 9 9 9}$ & $\mathbf{2 0 0 0}$ & Total no. \\
& $\%$ & $\%$ & of employers \\
\hline Manufacturing & 58 & 66 & 183042 \\
Agriculture, mining, utilities, construction & 41 & 45 & 250929 \\
Distribution \& consumer services & 59 & 72 & 624092 \\
Finance \& business services & 59 & 61 & 559591 \\
Transport, public administration \& other services & 64 & 74 & 438002 \\
TOTAL & & & \\
\hline Base/Coverage: all employers - 4001 & 58 & 66 & 2055656 \\
\hline
\end{tabular}

Base/Coverage: all employers - 4001 
7.1.4 The proportion of employers in each region who had carried out on-the-job training in the previous 12 months is shown below:

Table 52 Provision of on-the-job training by Government Office region of employer

\begin{tabular}{lccc}
\hline & $\mathbf{1 9 9 9}$ & $\mathbf{2 0 0 0}$ & $\begin{array}{c}\text { Total no. } \\
\text { of employers }\end{array}$ \\
\hline North East & 53 & 74 & 71976 \\
North West & 63 & 73 & 245697 \\
Yorkshire and the Humber & 70 & 75 & 179373 \\
East Midlands & 59 & 68 & 161272 \\
West Midlands & 64 & 66 & 200189 \\
Eastern & 52 & 66 & 233332 \\
London & 50 & 61 & 382198 \\
South East & 56 & 61 & 366035 \\
South West & 61 & 61 & 215584 \\
& & & \\
TOTAL & 58 & 66 & 2055656 \\
\hline
\end{tabular}

Base/Coverage: all employers - 4001

7.1.5 A variety of methods had been used to provide on-the-job training, most commonly training by a line manager or supervisor, or by other experienced staff in the company.

Table 53 Methods used to provide on-the-job training

\begin{tabular}{lcc}
\hline & $\mathbf{1 9 9 9}$ & $\mathbf{2 0 0 0}$ \\
& $\%$ & $\%$ \\
\hline Training by a line manager or supervisor & 65 & 78 \\
Training by other experienced staff in the company & 55 & 56 \\
Training by company training officer or specialist & 30 & 32 \\
$\quad$ Training staff & 11 & 24 \\
Training by equipment suppliers & 16 & 21 \\
Computer based training packages & 15 & 20 \\
Private sector training companies or consultancies & 4 & 5 \\
Other & \multicolumn{2}{l}{} \\
\hline Base/Coverage: all employers carrying out on-the-job training in the past 12 months - \\
3316
\end{tabular}


Chapter 8

Provision of J ob-Related Training and Reasons for Non-Provision 


\section{Provision of Job-Related Training and Reasons for Non- Provision}

\subsection{Introduction}

8.1.1 In this section we summarise:

- the proportion of employers who have provided training, either off-the-job or on-thejob, for any of the employees at the location over the previous 12 months

and

- for the 2000 study only, the reasons given by employers who have not provided any training for not having done so.

\subsection{Employers Providing Training}

8.2.1 Overall, in the 2000 study, three-quarters (76\%) of employers reported that they had provided employees at the location with either off-the-job or on-the-job training over the previous 12 months. This represents an increase from the $68 \%$ of employers who reported having provided training in the 1999 study.

Table 54 Provision of training

\begin{tabular}{lcc}
\hline & $\mathbf{1 9 9 9}$ & $\mathbf{2 0 0 0}$ \\
& $\%$ & $\%$ \\
\hline Off-the-job & 34 & 41 \\
On-the-job & 58 & 66 \\
Both & 24 & 31 \\
Either & 68 & 76 \\
\hline Base/Coverage: all employers -4001 & &
\end{tabular}

8.2.2 The figures from the 2000 study also show that $76 \%$ of employers who provide off-the-job training also provide on-the-job training, and that $46 \%$ of employers who provide on-the-job training also provide off-the-job training (the equivalent figures from the 1999 study were $71 \%$ and $41 \%)$. 
8.2.3 The larger the employer the more likely it is that they have provided training over the past 12 months. In establishments with 25 or more employees the provision of training is almost universal.

8.2.4 There has been a notable increase since the 1999 study amongst small establishments in the proportion of employers providing training over the previous 12 months.

Table 55 Provision of training by size of employer

\begin{tabular}{lcc|cc|cc|ccc}
\hline & \multicolumn{2}{c}{ Off-the-job } & \multicolumn{2}{c|}{ On-the-job } & \multicolumn{2}{c|}{ Both } & \multicolumn{3}{c}{ Either } \\
& 1999 & 2000 & 1999 & 2000 & 1999 & 2000 & 1999 & 2000 & Total no. \\
& $\%$ & $\%$ & $\%$ & $\%$ & $\%$ & $\%$ & $\%$ & $\%$ & of employers \\
\hline $1-4$ & 25 & 33 & 49 & 59 & 15 & 22 & 58 & 69 & 1480267 \\
$5-24$ & 47 & 54 & 77 & 81 & 37 & 45 & 87 & 90 & 428851 \\
$25-99$ & 72 & 78 & 85 & 89 & 62 & 70 & 95 & 97 & 117187 \\
$100-199$ & 82 & 92 & 88 & 94 & 74 & 87 & 97 & 99 & 17155 \\
$200-499$ & 89 & 96 & 94 & 93 & 83 & 90 & 99 & $100 *$ & 9163 \\
$500+$ & 91 & 98 & 94 & 92 & 86 & 90 & 99 & $100 *$ & 3033 \\
& & & & & & & & & \\
TOTAL & 34 & 41 & 58 & 66 & 24 & 31 & 68 & 76 & 2055656 \\
\hline
\end{tabular}

Base/Coverage: all employers - 4001

* over $99.5 \%$ and rounded up to $100 \%$

8.2.5 In the 2000 study employers in the transport, public administration and other services sector were most likely to have provided training in the previous 12 months; those in the agriculture, mining, construction and utilities sector least likely to have done so.

8.2.6 There have been increases in the proportion of employers providing training in all sectors since the 1999 study, with the largest increases occurring in the transport, public administration and other services, the manufacturing and the distribution and consumer services sectors.

Table 56 Provision of training by industry sector of employer

\begin{tabular}{|c|c|c|c|c|c|c|c|c|c|}
\hline & \multicolumn{2}{|c|}{ Off-the-job } & \multicolumn{2}{|c|}{ On-the-job } & \multicolumn{2}{|c|}{ Both } & \multicolumn{2}{|c|}{ Either } & \multirow{3}{*}{$\begin{array}{l}\text { Total no. } \\
\text { of employers }\end{array}$} \\
\hline & 1999 & 2000 & 1999 & 2000 & 1999 & 2000 & 1999 & 2000 & \\
\hline & $\%$ & $\%$ & $\%$ & $\%$ & $\%$ & $\%$ & $\%$ & $\%$ & \\
\hline Manufacturing & 30 & 44 & 58 & 66 & 21 & 33 & 66 & 77 & 183042 \\
\hline $\begin{array}{l}\text { Agriculture, mining, } \\
\text { utilities, construction }\end{array}$ & 31 & 35 & 41 & 45 & 17 & 20 & 54 & 60 & 250929 \\
\hline $\begin{array}{l}\text { Distribution \& } \\
\text { consumer services }\end{array}$ & 25 & 32 & 59 & 72 & 19 & 27 & 66 & 76 & 624092 \\
\hline $\begin{array}{l}\text { Finance \& business } \\
\text { services }\end{array}$ & 38 & 41 & 59 & 61 & 26 & 30 & 71 & 72 & 559591 \\
\hline $\begin{array}{l}\text { Transport, public } \\
\text { administration } \\
\text { and other services }\end{array}$ & 42 & 54 & 64 & 74 & 33 & 42 & 74 & 87 & 438002 \\
\hline TOTAL & 34 & 41 & 58 & 66 & 24 & 31 & 68 & 76 & 2055656 \\
\hline
\end{tabular}

Base/Coverage: all employers - 4001 
8.2.7 In the 2000 study, employers in the North West, Yorkshire and the Humber, the East Midlands and the North East were more likely than the national average to have provided training over the previous 12 months.

8.2.8 The proportion of employers providing training has increased in all regions since the 1999 study. A particularly large increase has occurred in the North East.

Table 57 Provision of training by Government Office region of employer

\begin{tabular}{|c|c|c|c|c|c|c|c|c|c|}
\hline & \multicolumn{2}{|c|}{ Off-the-job } & \multicolumn{2}{|c|}{ On-the-job } & \multicolumn{2}{|c|}{ Both } & \multicolumn{2}{|c|}{ Either } & \multirow{3}{*}{$\begin{array}{l}\text { Total no. } \\
\text { of employers }\end{array}$} \\
\hline & 1999 & 2000 & 1999 & 2000 & 1999 & 2000 & 1999 & 2000 & \\
\hline & $\%$ & $\%$ & $\%$ & $\%$ & $\%$ & $\%$ & $\%$ & $\%$ & \\
\hline North East & 34 & 42 & 53 & 74 & 30 & 36 & 58 & 80 & 71976 \\
\hline North West & 34 & 46 & 63 & 73 & 27 & 34 & 70 & 86 & 245697 \\
\hline $\begin{array}{l}\text { Yorkshire and the } \\
\text { Humber }\end{array}$ & 37 & 48 & 70 & 75 & 28 & 39 & 80 & 84 & 179373 \\
\hline East Midlands & 42 & 46 & 59 & 68 & 28 & 33 & 72 & 81 & 161272 \\
\hline West Midlands & 31 & 37 & 64 & 66 & 24 & 28 & 72 & 74 & 200189 \\
\hline Eastern & 34 & 37 & 52 & 66 & 19 & 27 & 66 & 76 & 233332 \\
\hline London & 28 & 38 & 50 & 61 & 19 & 27 & 60 & 72 & 382198 \\
\hline South East & 32 & 39 & 56 & 61 & 22 & 34 & 66 & 66 & 366035 \\
\hline South West & 41 & 39 & 61 & 61 & 29 & 26 & 72 & 74 & 215584 \\
\hline TOTAL & 34 & 41 & 58 & 66 & 24 & 31 & 68 & 76 & 2055656 \\
\hline
\end{tabular}

Base/Coverage: all employers - 4001 


\subsection{Reasons why Training not Provided over Previous 12 Months}

8.3.1 Employers who had not provided either off-the-job or on-the-job training over the previous 12 months were asked why they had not done so.

8.3.2 By far the most common reason reported was that the skills that their employees currently have met their needs, so training was not needed.

\section{Table 58 Reasons why training not provided}

\begin{tabular}{ll}
\hline & $\%$ \\
\hline $\begin{array}{l}\text { Existing skills of employees meet our needs so training } \\
\text { Not needed }\end{array}$ & 77 \\
New recruits are sufficient to obtain the skills required / & 9 \\
$\quad$ already have the required skills & 4 \\
Lack of finance / cannot afford it & 2 \\
Training programme not yet in place & 2 \\
Employees too busy to give training & 2 \\
Employees learn from experience & 5 \\
Other & 5
\end{tabular}

Base/Coverage: all employers who had not provided training in the previous 12 months -333

8.3.3 Due to the small number of employers to whom the question was applicable, it is not possible to provide analysis by establishment size, industry sector or region.

8.3.4 Nine out of ten (91\%) of those not providing training over the previous 12 months stated that all or nearly all of their staff were fully proficient at their job. This compares with the $82 \%$ of those who had not provided any training over the previous 12 months who felt this way. 
Chapter 9

Cost to Employers of Providing J ob-Related Training 


\section{Cost to Employers of Providing Job-Related Training}

\subsection{Introduction}

9.1.1 The 2000 Learning and Training at Work study collected information that has enabled the cost to employers of providing job-related training to be calculated. A similar study, Employer Provided Training in the UK 1993, was carried out by IFF for the Department of Education and Employment as part of the EC sponsored Continuing Vocational Training Survey (CVTS), administered by Eurostat and carried out in each member state.

9.1.2 Headline results from the two studies have been compared. However, it should be noted that the coverage of Learning and Training at Work 2000 was broader, in terms of both the characteristics of the employers interviewed and in the types of training included.

9.1.3 Learning and Training at Work 2000 covered employers with 1 or more employees in England : CVTS covered employers with 10 or more employees in the UK.

All types of off-the-job training given away from the immediate work position funded or arranged by employers were included in Learning and Training at Work 2000 : the off-thejob cost data in CVTS was restricted to that relating to training courses planned or organised by employers.

All types of on-the-job training given at the desk or place where the person usually works were included in Learning and Training at Work 2000. In CVTS induction training and training allowing the employee to become familiar with the company or working environment was excluded, as was the cost of practising skills taught by on-the-job means.

9.1.4 The number of datasheets collected in Learning and Training at Work 2000 from employers with fewer than 10 employees was too small to allow results to be reliably projected up to provide national estimates. These were therefore excluded from analysis and all data pertaining to the cost of training shown in this report relates to employers with 10 or more employees.

\subsection{Costs of Providing Training}

9.2.1 The 2000 Learning and Training at Work study indicates that the total cost to employers with 10 or more employees of providing training over the previous 12 months was $£ 23.5 \mathrm{bn}$. This figure can be broken down as follows:

Off-the-job training

- Course related

- Other, eg seminars, workshops

On-the-job
$£ 14.5 \mathrm{bn}$

$£ 11.8 \mathrm{bn}$

$£ 2.8 \mathrm{bn}$

$£ 9.0 \mathrm{bn}$

9.2.2 The 1993 CVTS study indicated that the cost to employers of providing training over the previous 12 months was $£ 10.6 \mathrm{bn}$, of which $£ 8.0 \mathrm{bn}$ was off-the-job and $£ 2.6 \mathrm{bn}$ on-the-job training. The reader should however note the difference in coverage of the two surveys and also the broader definition of both off-the-job and on-the-job training employed in the 2000 Learning and Training at Work survey described earlier. 
9.2.3 The distribution of training costs by size of employer is shown below. It can be seen that employers with 10-99 employees amount for approaching two-thirds (63\%) of total expenditure.

Table 59 Training costs by size of employer

\begin{tabular}{|c|c|c|c|c|c|c|c|c|c|c|}
\hline & \multicolumn{2}{|c|}{ Total } & \multicolumn{2}{|c|}{ Off-the-job } & \multicolumn{4}{|c|}{$\begin{array}{c}\text { Course related } \\
\text { off-the-job }\end{array}$} & \multicolumn{2}{|c|}{ On-the-job } \\
\hline $10-24$ & $£ 5.4 \mathrm{bn}$ & 23 & $£ 3.3 b n$ & 22 & $£ 2.6 \mathrm{bn}$ & 22 & $£ 0.7 \mathrm{bn}$ & 25 & $£ 2.1 \mathrm{bn}$ & 24 \\
\hline $25-99$ & $£ 9.3 \mathrm{bn}$ & 40 & $£ 6.0 \mathrm{bn}$ & 42 & $£ 4.8 \mathrm{bn}$ & 41 & $£ 1.3 \mathrm{bn}$ & 46 & $£ 3.2 \mathrm{bn}$ & 36 \\
\hline 100-199 & $£ 2.5 \mathrm{bn}$ & 11 & $£ 1.5 \mathrm{bn}$ & 11 & $£ 1.3 \mathrm{bn}$ & 11 & $£ 0.2 \mathrm{bn}$ & 9 & $£ 1.0 \mathrm{bn}$ & 11 \\
\hline $200-499$ & $£ 3.4 \mathrm{bn}$ & 14 & $£ 2.2 \mathrm{bn}$ & 15 & $£ 1.9 \mathrm{bn}$ & 16 & $£ 0.3 \mathrm{bn}$ & 12 & $£ 1.2 \mathrm{bn}$ & 13 \\
\hline $500+$ & $£ 3.0 \mathrm{bn}$ & 13 & $£ 1.4 \mathrm{bn}$ & 10 & $£ 1.2 \mathrm{bn}$ & 11 & $£ 0.2 \mathrm{bn}$ & 8 & $£ 1.5 \mathrm{bn}$ & 17 \\
\hline Total & $£ 23.5 \mathrm{bn}$ & 100 & $£ 14.5 \mathrm{bn}$ & 100 & $£ 11.8 \mathrm{bn}$ & 100 & $£ 2.8 \mathrm{bn}$ & 100 & $£ 9.0 \mathrm{bn}$ & 100 \\
\hline
\end{tabular}

9.2.4 The distribution of training costs by industry sector is shown below. It can be seen that the transport, public and administration and other services sector accounts for about $40 \%$ of total expenditure and is the highest spending sector on both off-the-job and on-the-job training.

Table 60 Training costs by industry sector of employer

\begin{tabular}{|c|c|c|c|c|c|c|c|c|c|c|}
\hline & \multicolumn{2}{|c|}{ Total } & \multicolumn{2}{|c|}{ Off-the-job } & \multicolumn{2}{|c|}{$\begin{array}{c}\text { Course related } \\
\text { off-the-job }\end{array}$} & \multicolumn{2}{|c|}{$\begin{array}{c}\text { Other } \\
\text { off-the-job }\end{array}$} & \multicolumn{2}{|c|}{ On-the-job } \\
\hline Manufacturing & $£ 2.3 \mathrm{bn}$ & 10 & $£ 1.3 b n$ & 9 & $£ 1.1 \mathrm{bn}$ & 9 & $£ 0.2 \mathrm{bn}$ & 7 & $£ 1.0 \mathrm{bn}$ & 11 \\
\hline Agriculture, & & & & & & & & & & \\
\hline $\begin{array}{l}\text { mining, } \\
\text { utilities \& } \\
\text { construction }\end{array}$ & $£ 1.7 \mathrm{bn}$ & 7 & $£ 1.0 \mathrm{bn}$ & 7 & $£ 0.8 b n$ & 7 & $£ 0.2 \mathrm{bn}$ & 6 & $£ 0.7 \mathrm{bn}$ & 8 \\
\hline Distribution \& & & & & & & & & & & \\
\hline $\begin{array}{l}\text { consumer } \\
\text { services }\end{array}$ & $£ 3.8 \mathrm{bn}$ & 16 & $£ 2.4 \mathrm{bn}$ & 16 & $£ 2.1 \mathrm{bn}$ & 17 & $£ 0.3 \mathrm{bn}$ & 12 & $£ 1.4 \mathrm{bn}$ & 16 \\
\hline Finance \& & & & & & & & & & & \\
\hline $\begin{array}{l}\text { business } \\
\text { services }\end{array}$ & $£ 6.6 \mathrm{bn}$ & 28 & $£ 4.3 \mathrm{bn}$ & 30 & $£ 3.7 \mathrm{bn}$ & 31 & $£ 0.7 \mathrm{bn}$ & 24 & $£ 2.2 \mathrm{bn}$ & 25 \\
\hline $\begin{array}{l}\text { Transport, } \\
\text { public }\end{array}$ & & & & & & & & & & \\
\hline $\begin{array}{l}\text { administration } \\
\text { and other } \\
\text { services }\end{array}$ & $£ 9.2 \mathrm{bn}$ & 39 & $£ 5.5 b n$ & 38 & $£ 4.1 \mathrm{bn}$ & 35 & $£ 1.4 \mathrm{bn}$ & 50 & $£ 3.6 \mathrm{bn}$ & 40 \\
\hline Total & $£ 23.5 \mathrm{bn}$ & 100 & $£ 14.5 \mathrm{bn}$ & 100 & $£ 11.8 \mathrm{bn}$ & 100 & $£ 2.8 \mathrm{bn}$ & 100 & $£ 9.0 \mathrm{bn}$ & 100 \\
\hline
\end{tabular}


9.2.5 The distribution of training costs by region is shown below. London, the North West and the South East are the regions spending the most on training.

Table 61 Training costs by Government Office region of employer

\begin{tabular}{|c|c|c|c|c|c|c|c|c|c|c|}
\hline \multirow[b]{2}{*}{ North East } & \multicolumn{2}{|c|}{ Total } & \multicolumn{2}{|c|}{$\begin{array}{r}\text { Off-the-job } \\
\%\end{array}$} & \multicolumn{2}{|c|}{$\begin{array}{c}\text { Course related } \\
\text { off-the-job } \\
\%\end{array}$} & \multicolumn{2}{|c|}{$\begin{array}{c}\text { Other off-the- } \\
\text { job } \\
\\
\% \\
\end{array}$} & \multicolumn{2}{|c|}{$\begin{array}{r}\text { On-the-job } \\
\%\end{array}$} \\
\hline & $£ 1.8 \mathrm{bn}$ & 8 & $£ 1.0 \mathrm{bn}$ & 7 & $£ 0.9 \mathrm{bn}$ & 7 & $£ 0.2 \mathrm{bn}$ & 6 & $£ 0.7 \mathrm{bn}$ & 8 \\
\hline North West & $£ 3.9 \mathrm{bn}$ & 17 & $£ 2.4 \mathrm{bn}$ & 17 & $£ 2.1 \mathrm{bn}$ & 18 & $£ 0.3 \mathrm{bn}$ & 12 & $1.5 \mathrm{bn}$ & 17 \\
\hline $\begin{array}{l}\text { Yorkshire and the } \\
\text { Humber }\end{array}$ & $£ 1.9 \mathrm{bn}$ & 8 & $£ 1.2 \mathrm{bn}$ & 8 & £1.0bn & 8 & $£ 0.2 \mathrm{bn}$ & 8 & $£ 0.8 \mathrm{bn}$ & 9 \\
\hline East Midlands & $£ 1.1$ & 5 & $£ 0.6$ & 4 & $f 0,5$ & 4 & $£ 0.1 \mathrm{bn}$ & 4 & $£ 0.6 \mathrm{bn}$ & 6 \\
\hline & & 9 & & 8 & & 8 & & 7 & & 10 \\
\hline & $E$ & 8 & $£ 1$. & 9 & $£ 1.1$ & 10 & $£ 0$. & 9 & & 7 \\
\hline Lono & $£ 5.3$ & 23 & $£ 3.4 \mathrm{bn}$ & 23 & $£ 2.4 \mathrm{bn}$ & 21 & $£ 1.0 \mathrm{bn}$ & 36 & $£ 1$. & 22 \\
\hline South East & $£ 3.6 \mathrm{bn}$ & 15 & $£ 2.2 \mathrm{bn}$ & 15 & $£ 1.8 \mathrm{bn}$ & 16 & $£ 0.3 \mathrm{bn}$ & 13 & $£ 1.4 \mathrm{bn}$ & 16 \\
\hline South West & $£ 1.7 \mathrm{bn}$ & 7 & $£ 1.2 \mathrm{bn}$ & 8 & $£ 1.0 \mathrm{bn}$ & 9 & $£ 0.2 \mathrm{bn}$ & 6 & $£ 0.5 \mathrm{bn}$ & 6 \\
\hline Total & $£ 23.5 \mathrm{bn}$ & 100 & $£ 14.5 \mathrm{bn}$ & 100 & $£ 11.8 \mathrm{bn}$ & 100 & $£ 2.8 \mathrm{bn}$ & 100 & $£ 9.0 \mathrm{bn}$ & 100 \\
\hline
\end{tabular}

Base/Coverage: all employers with 10 or more employees providing training costs information - 711 


\subsection{Cost Components}

9.3.1 The composition of employer training costs is shown below. Also shown is the question number on the datasheet from which the data has been obtained. The reader should refer to the datasheet which is provided in the Technical Appendix to obtain a fuller definition of each cost area.

\section{Off-the-job training}

a) Course related

Trainee labour costs (Q1-3)

$£ 3544 m$

Fees to external providers (Q4)

$£ 1919 m$

On-site training centre $(\mathrm{Q} 6 \mathrm{a} / \mathrm{b})$

$£ 1243 m$

Off-site training centre belonging to the same company (Q7)

$£ 535 \mathrm{~m}$

Training management (Q8-10)

$£ 3735 m$

Non-training centre equipment and materials (Q11)

$£ 376 \mathrm{~m}$

Travel and subsistence (Q12)

$£ 390 \mathrm{~m}$

Levies minus grants (Q13-14)

$£ 8 m$

Total course related

$£ 11750 m$

b) Other

Labour costs (Q15-17)

$£ 2051 \mathrm{~m}$

Fees to external providers (Q18)

$£ 702 \mathrm{~m}$

Total other off-the-job training

$£ 2753 m$

Total off-the-job training

$£ 14503 m$

On-the-job training

Trainees' labour costs (Q19-21)

$£ 4736 m$

Trainers' labour costs (Q22-24)

$£ 4288 m$

Total on-the-job training

$£ 9024 m$

Total

$£ 23527 m$ 


\subsection{Average costs per employee}

9.4.1 The average annual cost of providing training per employee was $£ 1333$. This figure can be broken down as follows:

$\begin{array}{cr}\text { Off-the-job training } & £ 822 \\ - \text { course related } & £ 666 \\ \text { - other } & £ 156 \\ \text { On-the-job training } & £ 511\end{array}$

9.4.2 The average cost of training per employee for various sizes of establishment is shown below. Broadly speaking, the average cost of training declines as the employer becomes larger.

Table 62 Average cost of training per employee by size of employer

\begin{tabular}{lccccc}
\hline & Total & Off-the-job & $\begin{array}{c}\text { Course related } \\
\text { off-the-job }\end{array}$ & $\begin{array}{c}\text { Other off- } \\
\text { the-job }\end{array}$ & On-the-job \\
\hline $10-24$ & $£ 1627$ & $£ 985$ & $£ 777$ & $£ 207$ & $£ 643$ \\
$25-99$ & $£ 1609$ & $£ 1047$ & $£ 825$ & $£ 222$ & $£ 562$ \\
$100-199$ & $£ 1084$ & $£ 671$ & $£ 569$ & $£ 103$ & $£ 413$ \\
$200-499$ & $£ 1184$ & $£ 775$ & $£ 657$ & $£ 118$ & $£ 409$ \\
$500+$ & $£ 873$ & $£ 424$ & $£ 361$ & $£ 62$ & $£ 449$ \\
& & & & & \\
TOTAL & $£ 1333$ & $£ 822$ & $£ 666$ & $£ 156$ & $£ 511$ \\
\hline
\end{tabular}

Base/Coverage: all employers with 10 or more employees providing training costs information -711

9.4.3 The average cost of training per employee was highest in the finance and business services sector and lowest in the manufacturing sector.

Table 63 Average cost of training per employee by industry sector of employer

\begin{tabular}{|c|c|c|c|c|c|}
\hline & Total & Off-the-job & $\begin{array}{l}\text { Course related } \\
\text { off-the-job }\end{array}$ & $\begin{array}{l}\text { Other off- } \\
\text { the-job }\end{array}$ & On-the-job \\
\hline Manufacturing & $£ 606$ & $£ 335$ & $£ 283$ & $£ 52$ & $£ 271$ \\
\hline $\begin{array}{l}\text { Agriculture, mining, } \\
\text { utilities, construction }\end{array}$ & $£ 1111$ & $£ 651$ & $£ 535$ & $£ 116$ & $£ 459$ \\
\hline $\begin{array}{l}\text { Distribution \& } \\
\text { consumer services }\end{array}$ & $£ 699$ & $£ 437$ & $£ 377$ & $£ 60$ & $£ 262$ \\
\hline $\begin{array}{l}\text { Finance \& business } \\
\text { services }\end{array}$ & $£ 1416$ & $£ 933$ & $£ 789$ & $£ 144$ & $£ 483$ \\
\hline $\begin{array}{l}\text { Transport, public } \\
\text { administration } \\
\text { and other services }\end{array}$ & $£ 1209$ & $£ 730$ & $£ 547$ & $£ 183$ & $£ 479$ \\
\hline TOTAL & $£ 1333$ & $£ 822$ & $£ 666$ & $£ 156$ & $£ 511$ \\
\hline
\end{tabular}


9.4.4 The average cost of training per employee varied by region as shown below.

Table 64 Average cost of training per employee by Government Office region of employer

\begin{tabular}{lccccc}
\hline & Total & Off-the-job & $\begin{array}{c}\text { Course related } \\
\text { off-the-job }\end{array}$ & $\begin{array}{c}\text { Other off- } \\
\text { the-job }\end{array}$ & On-the-job \\
\hline North East & $£ 1725$ & $£ 1005$ & $£ 837$ & $£ 168$ & $£ 720$ \\
North West & $£ 1347$ & $£ 828$ & $£ 718$ & $£ 110$ & $£ 520$ \\
Yorkshire and the & $£ 872$ & $£ 526$ & $£ 433$ & $£ 93$ & $£ 347$ \\
$\quad$ Humber & $£ 626$ & $£ 315$ & $£ 249$ & $£ 66$ & $£ 311$ \\
East Midlands & $£ 885$ & $£ 487$ & $£ 406$ & $£ 80$ & $£ 398$ \\
West Midlands & $£ 816$ & $£ 567$ & $£ 466$ & $£ 100$ & $£ 250$ \\
Eastern & $£ 1282$ & $£ 816$ & $£ 577$ & $£ 239$ & $£ 466$ \\
London & $£ 958$ & $£ 580$ & $£ 489$ & $£ 92$ & $£ 378$ \\
South East & $£ 765$ & $£ 535$ & $£ 464$ & $£ 71$ & $£ 230$ \\
South West & & & & & \\
& $£ 1333$ & $£ 822$ & $£ 666$ & $£ 156$ & $£ 511$ \\
TOTAL & & & &
\end{tabular}

\subsection{Average costs per trainee}

9.5.1 To provide data on the total cost of training per trainee, we need to know the number of employees receiving either off-the-job or on-the-job training. The way in which we collected information on the number of employees receiving training does not allow us to calculate the numbers receiving either off-the-job or on-the-job training. However, it is possible to measure separately the cost per trainee of each of the three elements of training covered.

9.5.2 The costs of training per trainee were as follows:

Course related off-the-job training $\quad £ 2132$

Other off-the-job training $\quad £ 1183$

On-the-job training $\quad £ 1173$

9.5.3 Costs per trainee vary by size of establishment as shown below.

Table 65 Average cost of training per trainee by size of employer

\begin{tabular}{|c|c|c|c|}
\hline & $\begin{array}{c}\text { Course related } \\
\text { off-the-job } \\
\text { training }\end{array}$ & $\begin{array}{c}\text { Other off-the-job } \\
\text { training }\end{array}$ & $\begin{array}{c}\text { On-the-job } \\
\text { training }\end{array}$ \\
\hline $10-24$ & $£ 3209$ & $£ 1200$ & $£ 1113$ \\
\hline $25-99$ & $£ 2964$ & $£ 1930$ & $£ 1164$ \\
\hline 100-199 & $£ 1554$ & $£ 818$ & $£ 925$ \\
\hline $200-499$ & $£ 1830$ & $£ 941$ & $£ 1353$ \\
\hline $500+$ & $£ 996$ & $£ 479$ & $£ 1323$ \\
\hline Total & $£ 2132$ & $£ 1183$ & $£ 1173$ \\
\hline
\end{tabular}


9.5.4 Costs per trainee vary by industry sector as shown below.

Table 66 Average cost of training per trainee by industry sector of employer

\begin{tabular}{|c|c|c|c|}
\hline & $\begin{array}{l}\text { Course related } \\
\text { off-the-job } \\
\text { training }\end{array}$ & $\begin{array}{l}\text { Other off-the-job } \\
\text { training }\end{array}$ & $\begin{array}{c}\text { On-the-job } \\
\text { training }\end{array}$ \\
\hline Manufacturing & $£ 1786$ & $£ 1132$ & $£ 1041$ \\
\hline $\begin{array}{l}\text { Agriculture, mining, utilities \& } \\
\text { construction }\end{array}$ & $£ 2139$ & $£ 874$ & $£ 1517$ \\
\hline $\begin{array}{l}\text { Distribution \& consumer } \\
\text { services }\end{array}$ & $£ 2340$ & $£ 848$ & $£ 1013$ \\
\hline Finance \& business services & $£ 2855$ & $£ 1234$ & $£ 1399$ \\
\hline $\begin{array}{l}\text { Transport, public } \\
\text { administration and other } \\
\text { services }\end{array}$ & $£ 1749$ & $£ 1351$ & $£ 1131$ \\
\hline Total & $£ 2132$ & $£ 1183$ & $£ 1173$ \\
\hline
\end{tabular}

9.5.5 The cost of training per trainee varies by region as in the table below.

Table 67 Average cost of training per trainee by Government Office region of employer

\begin{tabular}{lccc}
\hline & $\begin{array}{c}\text { Course } \\
\text { related } \\
\text { off-the-job } \\
\text { training }\end{array}$ & $\begin{array}{c}\text { Other off-the-job } \\
\text { training }\end{array}$ & $\begin{array}{c}\text { On-the- } \\
\text { job } \\
\text { training }\end{array}$ \\
\hline North East & $£ 1764$ & $£ 672$ & $£ 981$ \\
North West & $£ 2254$ & $£ 811$ & $£ 1023$ \\
Yorkshire and the & $£ 2118$ & $£ 1298$ & $£ 1175$ \\
$\quad$ Humber & $£ 1372$ & $£ 1065$ & $£ 1302$ \\
East Midlands & $£ 1964$ & $£ 779$ & $£ 926$ \\
West Midlands & $£ 2058$ & $£ 994$ & $£ 838$ \\
Eastern & $£ 2599$ & $£ 2988$ & $£ 1547$ \\
London & $£ 1905$ & $£ 827$ & $£ 1415$ \\
South East & $£ 2751$ & $£ 971$ & $£ 1239$ \\
South West & & & \\
& $£ 2132$ & $£ 1183$ & $£ 1173$ \\
\hline Total & &
\end{tabular}

Base/Coverage: all employers with 10 or more employees providing training costs

information - 711 
Chapter 10 Awareness Of, and I nvolvement With, Training I nitiatives 


\section{Awareness Of, and Involvement with, Training Initiatives}

\subsection{Introduction}

10.1.1 In order to ascertain employers' involvement with a number of training initiatives, a series of questions were put to all employers covering:

- Awareness of, and involvement with, training initiatives

- Involvement and satisfaction with NVQs/SVQS

- Whether or not recognised as an Investor in People.

\subsection{Awareness Of Training Initiatives}

10.2.1 NVQS/SVQs are the initiative with the highest level of awareness, with nine out of ten employers (90\%) having heard of them.

10.2.2 Half or more had heard of Youth Training (63\%), Modern Apprenticeships (61\%) and the National Record of Achievement (53\%).

Fig $8 \quad$ Awareness of training initiatives

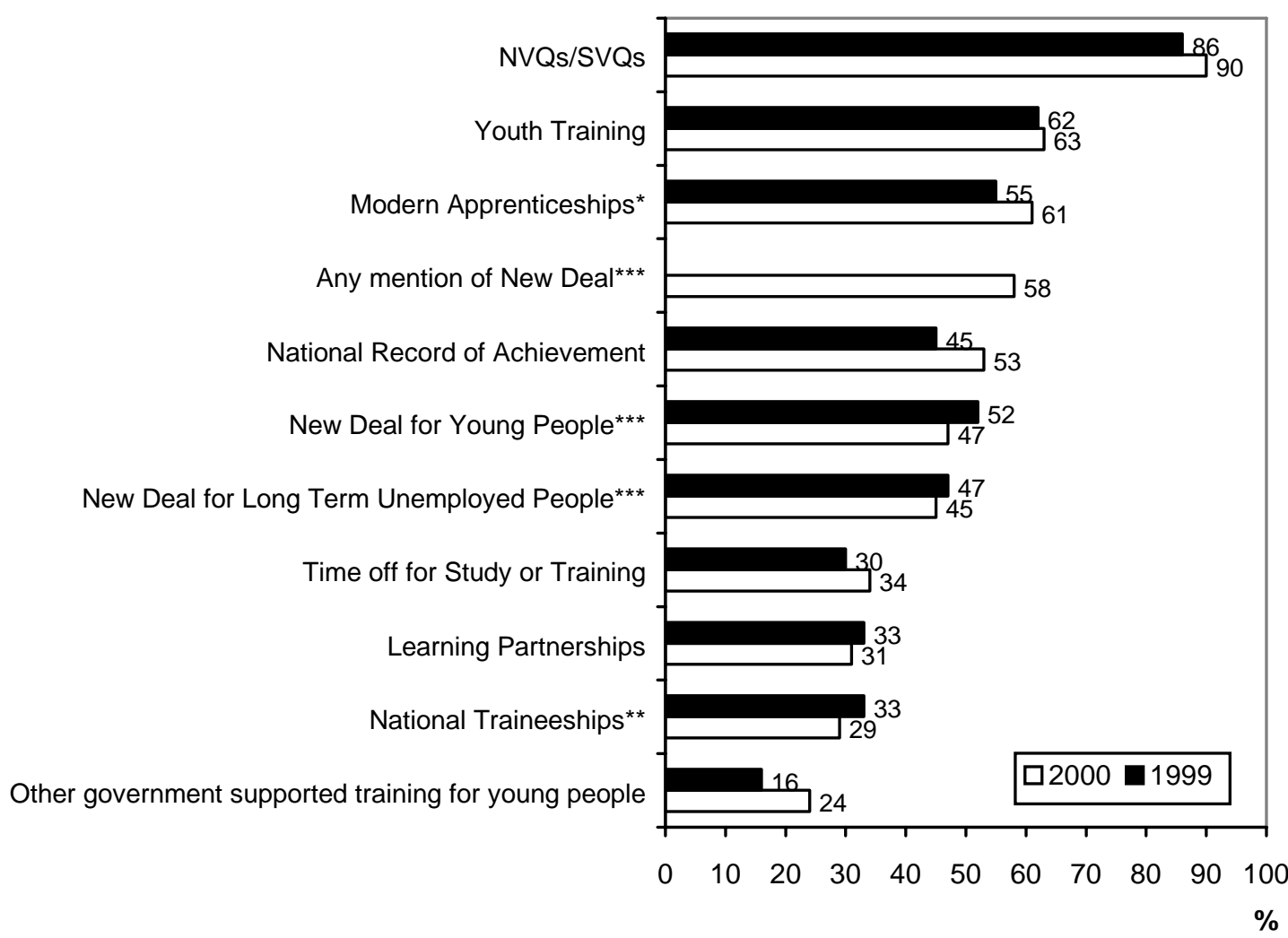

Base/Coverage: all employers - 4001

*recently relaunched as Advanced Modern Apprenticeships but referred to by former name in the questionnaire

**recently relaunched as Foundation Modern Apprenticeships but referred to by former name in the questionnaire

*** see 10.2 .3 
10.2.3 Since the 1999 study there has been an increase in awareness of the National Record of Achievement, Modern Apprenticeships (recently relaunched as Advanced Modern Apprenticeships but referred to under its former name in the questionnaire), other government supported training for young people, Time off for Study or Training and NVQs/SVQs. There has been a decrease in awareness of New Deal for Young People and National Traineeships (recently relaunched as Foundation Modern Apprenticeships but referred to under its former name in the questionnaire).

For the 2000 survey, a small change was made to the New Deal part of the Awareness of Training Initiatives question (Q30). In 1999, employers were asked about 'New Deal for Young People' and 'New Deal for Long Term Unemployed'. For the 2000 survey, a third category was also read out - 'New Deal'. The results presented here for 'Any mention of New Deal' are based on a positive response to any of the three options.

10.2.4 Awareness of initiatives generally increased with increasing employer size, as the table below shows. NVQs/SVQs are almost universally known amongst employers with 5 or more employees.

Table 68 Awareness of training initiatives by size of employer

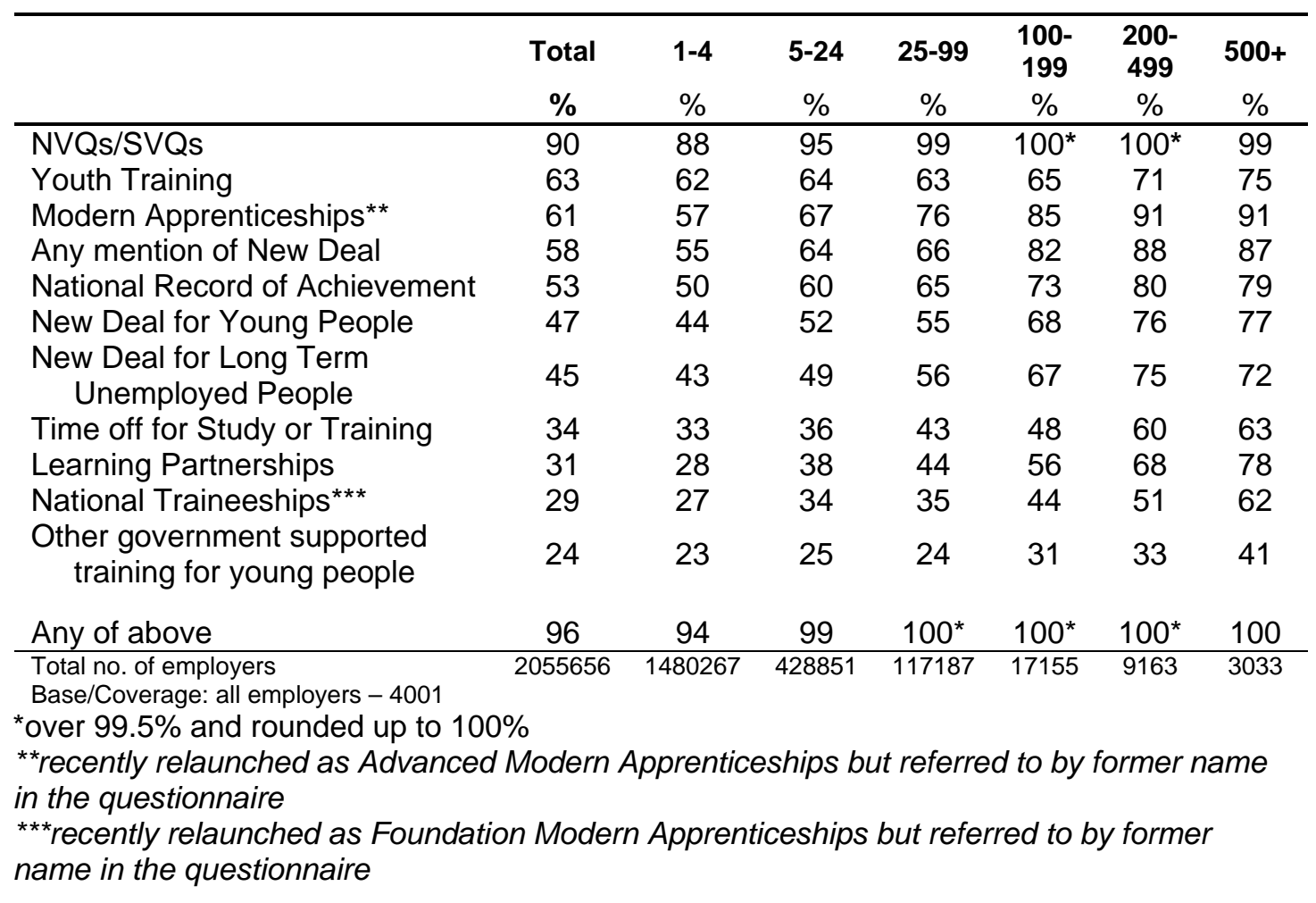


10.2.5 The following table illustrates the levels of awareness of the training initiatives by sector. High awareness of NVQs/SVQs is apparent across all sectors.

Table 69 Awareness of training initiatives by industry sector of employer

\begin{tabular}{|c|c|c|c|c|c|c|}
\hline & $\begin{array}{c}\text { Total } \\
\%\end{array}$ & $\begin{array}{c}\text { Manufac } \\
\text {-turing } \\
\%\end{array}$ & $\begin{array}{c}\text { Agric- } \\
\text { ulture, } \\
\text { mining, } \\
\text { utilities, } \\
\text { const- } \\
\text { ruction } \\
\%\end{array}$ & $\begin{array}{l}\text { Distribution } \\
\text { \& consumer } \\
\text { services } \\
\%\end{array}$ & $\begin{array}{l}\text { Finance \& } \\
\text { business } \\
\text { services } \\
\quad \%\end{array}$ & $\begin{array}{l}\text { Transport, } \\
\text { public } \\
\text { admin, } \\
\text { other } \\
\text { services } \\
\%\end{array}$ \\
\hline NVQs/SVQs & 90 & 87 & 90 & 86 & 93 & 94 \\
\hline Youth Training & 63 & 64 & 70 & 64 & 55 & 66 \\
\hline Modern Apprenticeships* & 61 & 60 & 63 & 59 & 62 & 61 \\
\hline Any mention of New Deal & 58 & 62 & 55 & 54 & 56 & 66 \\
\hline National Record of Achievement & 53 & 42 & 52 & 56 & 47 & 63 \\
\hline New Deal for Young People & 47 & 47 & 43 & 43 & 44 & 57 \\
\hline $\begin{array}{l}\text { New Deal for Long Term Unemployed } \\
\text { People }\end{array}$ & 45 & 49 & 40 & 43 & 41 & 54 \\
\hline Time off for Study or Training & 34 & 30 & 34 & 35 & 33 & 38 \\
\hline Learning Partnerships & 31 & 27 & 26 & 32 & 26 & 42 \\
\hline National Traineeships** & 29 & 28 & 34 & 33 & 20 & 33 \\
\hline $\begin{array}{l}\text { Other government supported training } \\
\text { or young people }\end{array}$ & 24 & 21 & 23 & 23 & 23 & 28 \\
\hline Any of above & 96 & 97 & 96 & 92 & 97 & 97 \\
\hline $\begin{array}{l}\text { Total no. of employers } \\
\text { Base/Coverage: all employers - } 4001 \\
\text { *recently relaunched as Advanced Mo } \\
\text { in the questionnaire } \\
\text { **recently relaunched as Foundation } \Lambda \\
\text { name in the questionnaire }\end{array}$ & $\begin{array}{l}2055656 \\
\text { rn Appre } \\
\text { dern App }\end{array}$ & 183042 & 250929 & 624092 & $\begin{array}{l}559591 \\
\text { former }\end{array}$ & $\begin{array}{l}438002 \\
\text { ame }\end{array}$ \\
\hline
\end{tabular}

10.2.6 The following table shows employer awareness of the six most widely known training initiatives by region.

Table 70 Awareness of training initiatives by Government Office region of employer

\begin{tabular}{|c|c|c|c|c|c|c|c|}
\hline & $\begin{array}{c}\text { NVQsI } \\
\text { SVQs } \\
\%\end{array}$ & $\begin{array}{c}\text { Youth } \\
\text { Training } \\
\%\end{array}$ & $\begin{array}{c}\text { Modern } \\
\text { Apprent- } \\
\text { iceships* } \\
\%\end{array}$ & $\begin{array}{c}\text { NRA } \\
\%\end{array}$ & $\begin{array}{c}\text { New Deal } \\
\text { for Young } \\
\text { People } \\
\%\end{array}$ & $\begin{array}{c}\text { New Deal for } \\
\text { Long Term } \\
\text { Unemployed } \\
\%\end{array}$ & $\begin{array}{l}\text { Total no. of } \\
\text { employers }\end{array}$ \\
\hline North East & 93 & 64 & 79 & 58 & 54 & 59 & 71976 \\
\hline North West & 91 & 62 & 70 & 61 & 51 & 52 & 245697 \\
\hline Yorkshire and the Humber & 92 & 61 & 61 & 59 & 67 & 57 & 179373 \\
\hline East Midlands & 97 & 65 & 67 & 67 & 61 & 56 & 161272 \\
\hline West Midlands & 93 & 73 & 62 & 56 & 50 & 39 & 200189 \\
\hline Eastern & 92 & 61 & 63 & 48 & 42 & 47 & 233332 \\
\hline London & 85 & 53 & 41 & 42 & 35 & 34 & 382198 \\
\hline South East & 84 & 65 & 58 & 54 & 40 & 39 & 366035 \\
\hline South West & 96 & 70 & 74 & 51 & 47 & 47 & 215584 \\
\hline TOTAL & 90 & 63 & 61 & 53 & 47 & 45 & 2055656 \\
\hline
\end{tabular}

Base/Coverage: all employers - 4001

*recently relaunched as Advanced Modern Apprenticeships but referred to by former name in the questionnaire 


\subsection{Involvement with Training Initiatives in the Last 12 Months}

10.3.1 Employers were asked with which of a number of training initiatives their company had had an involvement in the last 12 months, either through the company having been involved directly or through an employee having been on an initiative.

It should be noted that for all initiatives except the NRA and Learning Partnerships the wording was changed slightly between the 1999 and 2000 studies. In the 1999 study we asked "which of these initiatives, to your knowledge, has your company been involved with at some time in the last 12 months?" In the 2000 study we asked "have any of your employees been on any of the following initiatives in the last twelve months?" So results may not be strictly comparable.

10.3.2 Just over a quarter (27\%) of employers had been involved with one or more initiative. (It should be noted that although the question was only asked of employers who were aware of an initiative, results have been repercentaged and those reported relate to all employers).

10.3.3 Overall, the highest proportion of employers had been involved with NVQs/SVQs (18\%). Relative to the level of awareness, NVQs/SVQs was also the initiative with which the highest proportion of employers had been involved.

When examining the figures opposite, it should be borne in mind that the The Right to Time off for Study or Training (TfST) is employment legislation which gives employees aged 16 or 17 an entitlement to reasonable paid time off from work to achieve a qualification at NVQ level 2 or equivalent unless they have already achieved this qualification. As TfST is a right rather than a programme it is difficult to determine exactly what employers mean by employees having been on TfST. 
Fig 9

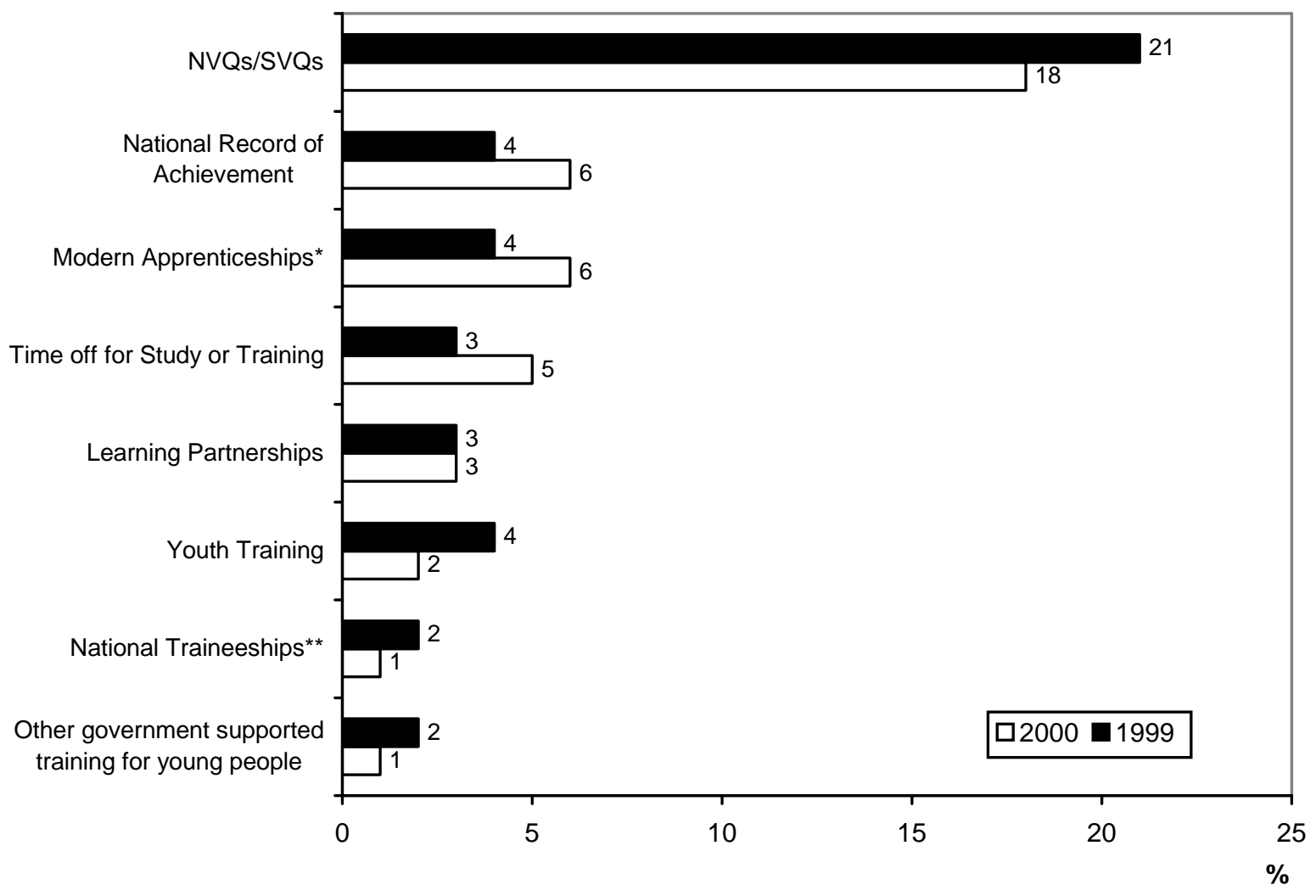

Base: all employers - 4001

Coverage: all employers aware of each initiative

*recently relaunched as Advanced Modern Apprenticeships but referred to by former name in the questionnaire

**recently relaunched as Foundation Modern Apprenticeships but referred to by former name in the questionnaire 
10.3.4 In the 2000 study, $5 \%$ of employers reported that they had taken on a New Deal recruit. Of this group $86 \%$ of employers had received a subsidy and $26 \%$ had not, indicating that some employers had taken on both recruits who had received a subsidy and those who had not. It is likely that the figure for unsubsidised recruits will be an underestimate as some employers who have taken on unsubsidised recruits will not know the person has been on New Deal. It is not possible to provide comparable data from the 1999 study.

10.3.5 Involvement with all initiatives increased with increasing establishment size.

Table 71 Involvement with training initiatives by size of employer

\begin{tabular}{|c|c|c|c|c|c|c|c|}
\hline & Total & 1-4 & $5-24$ & 25-99 & $\begin{array}{c}100- \\
199\end{array}$ & $\begin{array}{l}200- \\
499\end{array}$ & $500+$ \\
\hline NVQs/SVQs & 18 & 12 & 29 & 45 & 57 & 72 & 78 \\
\hline National Record of Achievement & 6 & 4 & 8 & 9 & 10 & 17 & 24 \\
\hline Modern Apprenticeships* & 6 & 4 & 7 & 14 & 21 & 38 & 43 \\
\hline Time off for Study or Training & 5 & 3 & 9 & 14 & 23 & 34 & 42 \\
\hline New Deal - subsidised recruit & 4 & 4 & 4 & 7 & 7 & 13 & 16 \\
\hline Learning Partnerships & 3 & 2 & 5 & 9 & 10 & 18 & 28 \\
\hline Youth Training & 2 & 1 & 3 & 4 & 6 & 7 & 11 \\
\hline New Deal - unsubsidised recruit & 1 & 1 & 1 & 4 & 3 & 6 & 10 \\
\hline National Traineeships** & 1 & * & 2 & 2 & 6 & 9 & 15 \\
\hline $\begin{array}{l}\text { Other government supported training for } \\
\text { Young people }\end{array}$ & 1 & * & 1 & 3 & 5 & 6 & 8 \\
\hline Any of above & 27 & 20 & 41 & 56 & 69 & 84 & 89 \\
\hline
\end{tabular}

Base: all employers - 4001

Coverage: all employers aware of each initiative

*recently relaunched as Advanced Modern Apprenticeships but referred to by former name in the questionnaire

**recently relaunched as Foundation Modern Apprenticeships but referred to by former name in the questionnaire 
10.3.6 Involvement with initiatives by industry sector is shown below.

Table 72 Involvement with training initiatives by industry sector of employer

\begin{tabular}{|c|c|c|c|c|c|c|}
\hline & $\begin{array}{c}\text { Total } \\
\%\end{array}$ & $\begin{array}{l}\text { Manufac } \\
\text {-turing } \\
\quad \%\end{array}$ & $\begin{array}{c}\text { Agric- } \\
\text { ulture, } \\
\text { mining, } \\
\text { utilities, } \\
\text { const- } \\
\text { ruction } \\
\%\end{array}$ & $\begin{array}{c}\text { Distribution } \\
\text { \& consumer } \\
\text { services } \\
\%\end{array}$ & $\begin{array}{l}\text { Finance \& } \\
\text { business } \\
\text { services } \\
\%\end{array}$ & $\begin{array}{c}\text { Transport, } \\
\text { public } \\
\text { admin, } \\
\text { other } \\
\text { services } \\
\%\end{array}$ \\
\hline NVQs/SVQs & 18 & 20 & 16 & 18 & 13 & 28 \\
\hline National Record of Achievement & 6 & 4 & 3 & 4 & 4 & 11 \\
\hline Modern Apprenticeships* & 6 & 7 & 10 & 3 & 5 & 7 \\
\hline Time off for Study or Training & 5 & 6 & 4 & 5 & 3 & 8 \\
\hline New Deal - subsidised recruit & 4 & 5 & 3 & 3 & 5 & 6 \\
\hline Learning Partnerships & 3 & 1 & 1 & 4 & * & 9 \\
\hline Youth Training & 2 & 1 & 1 & 2 & 2 & 3 \\
\hline New Deal - unsubsidised recruit & 1 & 3 & 1 & 1 & 1 & 2 \\
\hline National Traineeships** & 1 & 1 & 1 & 1 & * & 1 \\
\hline $\begin{array}{l}\text { Other government supported training for } \\
\text { young people }\end{array}$ & 1 & * & * & * & * & 2 \\
\hline Any of above & 27 & 28 & 25 & 26 & 21 & 39 \\
\hline
\end{tabular}

Base: all employers - 4001

Coverage: all employers aware of each initiative

*recently relaunched as Advanced Modern Apprenticeships but referred to by former name in the questionnaire

**recently relaunched as Foundation Modern Apprenticeships but referred to by former name in the questionnaire

10.3.7 Involvement with the six specific initiatives with which most employers had been involved is shown below on a regional basis.

Table 73 Involvement with training initiatives by Government Office region of employer

\begin{tabular}{|c|c|c|c|c|c|c|c|}
\hline & $\begin{array}{c}\text { Any } \\
\%\end{array}$ & $\begin{array}{c}\text { NVQs I } \\
\text { SVQs } \\
\%\end{array}$ & $\begin{array}{c}\text { NRA } \\
\%\end{array}$ & $\begin{array}{c}\text { Modern } \\
\text { Apprentice- } \\
\text { ships* } \\
\%\end{array}$ & $\begin{array}{c}\text { Time off } \\
\text { for } \\
\text { Studying } \\
\text { or } \\
\text { Training } \\
\%\end{array}$ & $\begin{array}{c}\text { New Deal } \\
\text { - subsi- } \\
\text { dised } \\
\text { recruits } \\
\% \\
\%\end{array}$ & $\begin{array}{c}\text { Learning } \\
\text { Partner- } \\
\text { ships } \\
\%\end{array}$ \\
\hline North East & 37 & 26 & 8 & 8 & 8 & 10 & 8 \\
\hline North West & 37 & 23 & 9 & 8 & 8 & 3 & 8 \\
\hline Yorkshire and the Humber & 31 & 18 & 4 & 7 & 12 & 8 & 3 \\
\hline East Midlands & 34 & 25 & 5 & 5 & 3 & 9 & 5 \\
\hline West Midlands & 33 & 25 & 8 & 5 & 4 & 5 & 2 \\
\hline Eastern & 24 & 18 & 3 & 5 & 4 & 3 & 1 \\
\hline London & 19 & 11 & 5 & 4 & 5 & 1 & 4 \\
\hline South East & 22 & 16 & 6 & 6 & 4 & 2 & 1 \\
\hline South West & 26 & 17 & 3 & 5 & 3 & 7 & 3 \\
\hline TOTAL & 27 & 18 & 6 & 6 & 5 & 4 & 3 \\
\hline
\end{tabular}

Base: all employers - 4001

Coverage: all employers aware of each initiative *recently relaunched as Advanced Modern Apprenticeships but referred to by former name in the questionnaire 


\subsection{Extent to which NVQs/SVQs Offered}

10.4.1 Overall, $18 \%$ of employers aware of NVQs/SVQs reported that they were currently offering the qualification to one or more of their employees at the location. This compares with the $16 \%$ of employers in the 1999 study offering NVQs/SVQs.

10.4.2 Of those aware of NVQs/SVQs larger employers are more likely to be offering them.

Table 74 Employers aware of NVQs/SVQs offering the qualification by size of employer

\begin{tabular}{lccc}
\hline & $\mathbf{1 9 9 9}$ & $\mathbf{2 0 0 0}$ & $\begin{array}{c}\text { No. of employers } \\
\text { aware of NVQS/SVQs }\end{array}$ \\
\hline $1-4$ & $\%$ & $\%$ & 1300663 \\
$5-24$ & 8 & 12 & 406446 \\
$25-99$ & 29 & 29 & 115611 \\
$100-199$ & 44 & 39 & 17088 \\
$200-499$ & 52 & 53 & 9138 \\
$500+$ & 66 & 64 & 3017 \\
TOTAL & 77 & 70 & 1851963 \\
\hline
\end{tabular}

Base/Coverage: all employers aware of NVQs/SVQs - 3864 
10.4.3 Of those employers aware of NVQs/SVQs, those in the transport, public administration and other services sector are most likely to be offering them : those in the finance and business services sector least likely to be doing so.

Table 75 Employers aware of NVQs/SVQs offering the qualification by industry sector of employer

\begin{tabular}{lccc}
\hline & $\mathbf{1 9 9 9}$ & $\mathbf{2 0 0 0}$ & $\begin{array}{c}\text { No. of employers } \\
\text { aware of NVQs/SVQs }\end{array}$ \\
\hline Manufacturing & $\%$ & $\%$ & 158668 \\
Agriculture, mining, utilities \& construction & 14 & 24 & 225244 \\
Distribution \& consumer services & 13 & 16 & 535674 \\
Finance \& business services & 15 & 20 & 519037 \\
Transport, public admin \& other services & 12 & 6 & 413340 \\
TOTAL & 25 & 29 & 1851963 \\
\hline
\end{tabular}

Base/Coverage: all employers aware of NVQs/SVQs - 3864

10.4.4 The proportion of those employers aware of NVQs/SVQs who are offering them varied from $9 \%$ in London to $27 \%$ in the North West.

Table 76 Employers aware of NVQs/SVQs offering the qualification by Government Office region of employer

\begin{tabular}{lccc}
\hline & $\mathbf{1 9 9 9}$ & $\mathbf{2 0 0 0}$ & $\begin{array}{c}\text { No. of employers } \\
\text { aware of NVQ/SVQs }\end{array}$ \\
\hline North East & $\%$ & $\%$ & 66750 \\
North West & 20 & 21 & 223800 \\
Yorkshire and the Humber & 19 & 27 & 165171 \\
East Midlands & 26 & 20 & 156076 \\
West Midlands & 19 & 26 & 186743 \\
Eastern & 14 & 23 & 214806 \\
London & 16 & 19 & 323052 \\
South East & 7 & 9 & 308438 \\
South West & 13 & 12 & 207128 \\
TOTAL & 23 & 18 & \\
Base/Coverage: all employers aware of NVQS/SVQs - 3864 & 16 & 18 &
\end{tabular}




\subsection{Average Proportion of Employees to whom NVQs/SVQs on Offer}

10.5.1 In the 2000 study, those employers offering NVQs/SVQs were asked to estimate the proportion of employees at their establishment to whom they were on offer (this information was not collected in the 1999 study).

NVQs/SVQs were on offer to $39 \%$ of employees on average.

10.5.2 The average proportion of employees to whom NVQs/SVQs are on offer amongst establishments in which the qualification is on offer varies by size of establishment as shown below.

Table 77 Average proportion of employees to whom NVQs/SVQs were on offer by size of employer

\begin{tabular}{ll}
\hline & $\%$ \\
\hline $1-4$ & 73 \\
$5-24$ & 50 \\
$25-99$ & 47 \\
$100-199$ & 49 \\
$200-499$ & 44 \\
$500+$ & 15 \\
& \\
TOTAL & 39 \\
\hline
\end{tabular}

Base/Coverage: all employers currently offering NVQs/SVQs - 1619

10.5.3 The average proportion of employees to whom NVQs/SVQs are on offer by size of establishment across all employers is as follows:

Table 78 Average proportion of employees to whom NVQs/SVQs were on offer by size of employer

\begin{tabular}{lc}
\hline & $\%$ \\
\hline $1-4$ & 9 \\
$5-24$ & 15 \\
$25-99$ & 19 \\
$100-199$ & 26 \\
$200-499$ & 28 \\
$500+$ & 11 \\
TOTAL & 17 \\
\hline
\end{tabular}

Base: all employers

Coverage: all employers currently offering NVQs/SVQs - 1619 
10.5.4 The distribution and consumer services sector is the one in which NVQs/SVQs are on offer to the highest proportion of employees.

Table 79 Average proportion of employees to whom NVQs/SVQs were on offer by industry sector of employer

\begin{tabular}{ll}
\hline & $\%$ \\
\hline Manufacturing & 35 \\
Agriculture, mining, utilities \& construction & 37 \\
Distribution \& consumer services & 46 \\
Finance \& business services & 35 \\
Transport, public admin \& other services & 40 \\
TOTAL & 39 \\
\hline Base/Coverage: all employers currently offering NVOs/SVOs - 1619
\end{tabular}

Base/Coverage: all employers currently offering NVQs/SVQs - 1619

10.5.5 Results by region are shown below.

Table 80 Average proportion of employees NVQs/SVQs on offer by Government Office region of employer

\begin{tabular}{lc}
\hline & $\%$ \\
\hline North East & 39 \\
North West & 41 \\
Yorkshire and the Humber & 41 \\
East Midlands & 38 \\
West Midlands & 43 \\
Eastern & 41 \\
London & 33 \\
South East & 35 \\
South West & 46 \\
TOTAL & 39 \\
\hline Base/Coverage: all employers currently offering NVOs/SVOs - 1619
\end{tabular}




\subsection{Level of Satisfaction with NVQs/SVQs}

10.6.1 Employers were asked to state how satisfied they were with the NVQs/SVQs on offer.

10.6.2 In the 2000 study three-quarters of employers were either very or fairly satisfied : this compares with the $78 \%$ who felt this way in the 1999 study. The proportion of employers reporting they are not at all satisfied has increased substantially since the 1999 study.

Table 81 Level of satisfaction with NVQs/SVQs on offer

\begin{tabular}{lcc}
\hline & $\mathbf{1 9 9 9}$ & $\mathbf{2 0 0 0}$ \\
& $\%$ & $\%$ \\
\hline Very satisfied & 29 & 29 \\
Fairly satisfied & 49 & 46 \\
Not very satisfied & 8 & 9 \\
Not at all satisfied & 2 & 9 \\
Not stated & 12 & 7 \\
\hline Base/Coverage: all employers currently offering NVQs/SVQs - 1619
\end{tabular}

10.6.3 High levels of satisfaction were expressed by employers of all sizes and in all industry sectors.

10.6.4 Employers were asked to state, without prompting, what their reasons were for being satisfied or dissatisfied with the NVQs/SVQs on offer.

A fifth (22\%) of the employers who stated that they were either very or fairly satisfied attributed this to the fact that NVQS/SVQs had improved the level of knowledge of their workforce. A similar proportion (18\%) felt that NVQs/SVQs matched individuals' needs.

The following table shows all reasons given for feeling satisfied with NVQs/SVQs put forward in the 2000 study by $5 \%$ or more of satisfied employers.

Table 82 Reasons for satisfaction with NVQs/SVQs

\begin{tabular}{lcc}
\hline & $\mathbf{1 9 9 9}$ & $\mathbf{2 0 0 0}$ \\
\hline & $\%$ & $\%$ \\
\hline Improves knowledge of employees & 21 & 22 \\
Relevance and focus of training has improved & 19 & 11 \\
Matches individuals' needs & 18 & 18 \\
Resulted in improved quality of work & 15 & 11 \\
Improved staff motivation & 12 & 8 \\
Assessments/trainers/providers of good quality & - & 7 \\
\hline
\end{tabular}

Base/Coverage: all employers feeling very / fairly satisfied with NVQs/SVQs on offer - 1331 
10.6.5 The principal reason put forward by those dissatisfied with NVQs/SVQs was the feeling that NVQs/SVQs did not cover all the skills that the company required (31\%). A similar proportion (28\%) felt that NVQs/SVQs did not meet the company's business needs.

The following table shows all reasons for feeling dissatisfied with NVQs/SVQs put forward in the 2000 study by $5 \%$ or more of dissatisfied employers.

Table 83 Reasons for dissatisfaction with NVQs/SVQs

\begin{tabular}{lcc}
\hline & $\mathbf{1 9 9 9}$ & $\mathbf{2 0 0 0}$ \\
& $\%$ & 31 \\
\hline Do not cover all the skills the company needs & 56 & 28 \\
Do not meet the company's business needs & 32 & 6 \\
Proved too bureaucratic & 23 & 13 \\
Problems with training provider & 15 & 7 \\
Not specific to our industry & 4 & \\
\hline Base/Coverage: all employers feeling not very / not at all satisfied with NVQs/SVQs on offer - 175
\end{tabular}

\subsection{Assessment of NVQs/SVQs}

10.7.1 All employers offering NVQs/SVQs were asked to give their opinion about the quality of assessment.

10.7.2 Approaching two-thirds (62\%) felt that the quality of assessment was very or fairly good : this figure is very similar to that reported in the 1999 study (61\%).

Table 84 Views on quality of assessment of NVQs/SVQs

\begin{tabular}{lcc}
\hline & $\mathbf{1 9 9 9}$ & $\mathbf{2 0 0 0}$ \\
& $\%$ & $\%$ \\
\hline Very good & 20 & 25 \\
Fairly good & 41 & 37 \\
Neither good nor poor & 10 & 9 \\
Fairly poor & 6 & 9 \\
Very poor & 2 & 1 \\
Don't know & 21 & 18 \\
\hline
\end{tabular}

Base/Coverage: all employers currently offering NVQs/SVQs - 1619 


\subsection{Investors in People}

10.8.1 Employers were asked in the 2000 study whether the establishment is formally recognised as an Investor in People. (This information was not collected in the 1999 study).

10.8.2 Overall $16 \%$ of employers are formally recognised as such.

10.8.3 The proportion recognised as an Investor in People increases with increasing size of establishment.

Table 85 Recognition as an Investor in People by size of employer

\begin{tabular}{lcc}
\hline & $\%$ & $\begin{array}{c}\text { No. of } \\
\text { employers }\end{array}$ \\
\hline $1-4$ & 13 & 1480267 \\
$5-24$ & 22 & 428851 \\
$25-99$ & 32 & 117187 \\
$100-199$ & 37 & 17155 \\
$200-499$ & 42 & 9163 \\
$500+$ & 48 & 3033 \\
TOTAL & 16 & 2055656 \\
\hline
\end{tabular}

Base/Coverage: all employers - 4001

10.8.4 Transport, public administration and other services is the sector in which the highest proportion of employers are recognised (21\%) : agriculture, mining, construction and utilities the sector in which the lowest proportion are.

Table 86 Recognition as an Investor in People by industry sector of employer

\begin{tabular}{lcc}
\hline & $\%$ & $\begin{array}{c}\text { No. of } \\
\text { employers }\end{array}$ \\
\hline Manufacturing & 10 & 183042 \\
Agriculture, mining, utilities \& construction & 8 & 250929 \\
Distribution \& consumer services & 19 & 624092 \\
Finance \& business services & 14 & 559591 \\
Transport, public admin \& other services & 21 & 438002 \\
TOTAL & 16 & 2055656 \\
\hline
\end{tabular}

Base/Coverage: all employers - 4001 
10.8.5 Results vary by region as shown below.

Table 87 Recognition as an Investor in People by Government Office region of employer

\begin{tabular}{lcc}
\hline & $\%$ & $\begin{array}{c}\text { No. of } \\
\text { employers }\end{array}$ \\
\hline North East & 19 & 71976 \\
North West & 20 & 245697 \\
Yorkshire and the Humber & 11 & 179373 \\
East Midlands & 18 & 161272 \\
West Midlands & 20 & 200189 \\
Eastern & 19 & 233332 \\
London & 18 & 382198 \\
South East & 13 & 366035 \\
South West & 10 & 215584 \\
TOTAL & & \\
\hline Base/Coverage: all employers - 4001 & 16 & 2055656 \\
\hline
\end{tabular}

10.8.6 Interestingly, the proportion of employers who feel all or nearly all of their employees are fully proficient at their job does not vary according to whether or not the establishment has Investor in People status, the figure in both cases being 85\%. 
Chapter 11

Young Employees Aged 16-24 


\section{Young Employees Aged 16-24}

\subsection{Employment of 16-24 Year Olds}

11.1.1 Employers were asked whether or not they currently employed any employees aged 16-24, and, if so, which age groups - 16-17 year olds, 18-19 year olds or 20-24 year olds.

11.1.2 Overall, approaching half of employers (45\%) employed 16-24 year olds, with 20-24 year olds most commonly being employed.

In the 1999 study, a smaller proportion of employers (37\%) employed 16-24 year olds. Employment of all three age groups, in particular that of 20-24 year olds, has increased.

Fig 10 Employment of 16-24 year olds

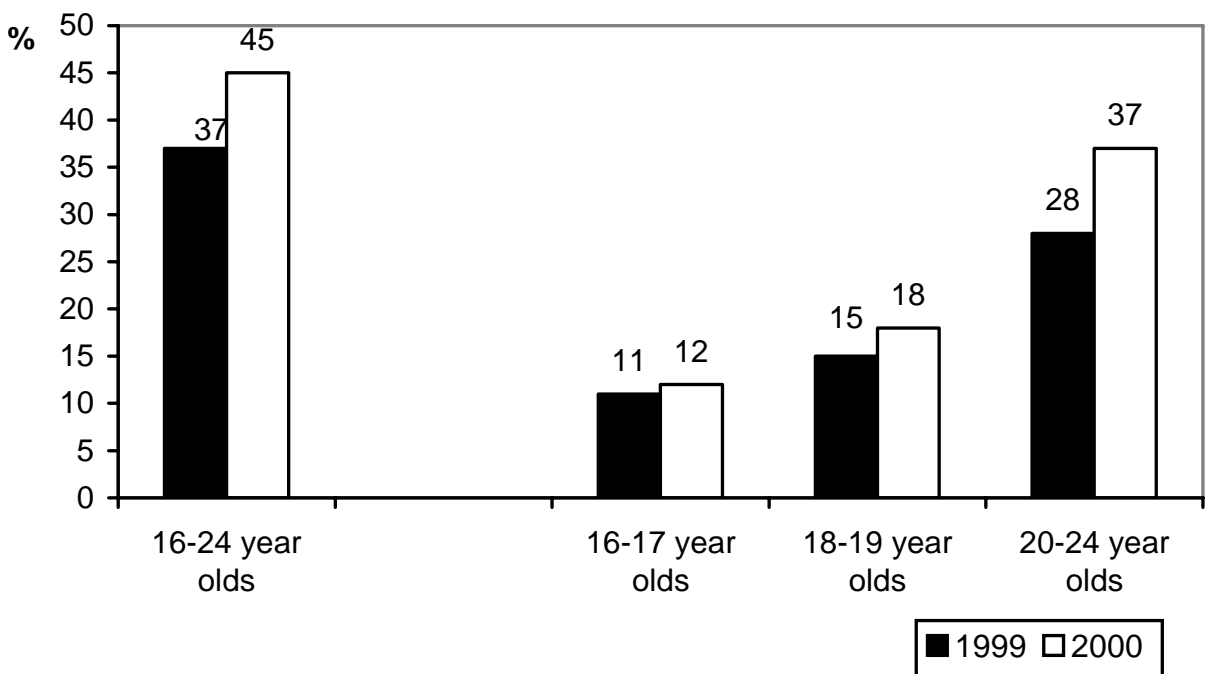

Base/Coverage: all employers - 4001 
11.1.3 Employers with 25 or more employees were more likely to employ $16-24$ year olds than those with 1-24 employees.

All sizes of employers are more likely to employ 20-24 year olds than 18-19 year olds and more likely to employ 18-19 year olds than 16-17 year olds.

Table 88 Employment of 16-24 year olds by size of employer

\begin{tabular}{lccccc}
\hline & $\begin{array}{c}\mathbf{1 6 - 2 4} \\
\text { year olds } \\
\%\end{array}$ & $\begin{array}{c}\mathbf{1 6 - 1 7} \\
\text { year olds } \\
\%\end{array}$ & $\begin{array}{c}\mathbf{1 8 - 1 9} \\
\text { year olds } \\
\%\end{array}$ & $\begin{array}{c}\mathbf{2 0 - 2 4} \\
\text { year olds } \\
\%\end{array}$ & $\begin{array}{c}\text { Total no. of } \\
\text { employers }\end{array}$ \\
\hline $1-4$ & 31 & 6 & 9 & 24 & 1480267 \\
$5-24$ & 75 & 23 & 37 & 65 & 428851 \\
$25-99$ & 91 & 34 & 57 & 88 & 117187 \\
$100-199$ & 95 & 35 & 69 & 94 & 17155 \\
$200-499$ & 96 & 47 & 76 & 96 & 9163 \\
$500+$ & 95 & 50 & 81 & 94 & 3033 \\
TOTAL & 45 & 12 & 18 & 37 & 2055656 \\
\hline
\end{tabular}

11.1.4 Employers in the distribution and consumer services sector are most prone to employ 16-24 year olds : those in the agriculture, mining, utilities and construction sector least likely to do so.

Employers in all sectors are more likely to employ 20-24 year olds than 18-19 or 16-17 year olds.

Table 89 Employment of 16-24 year olds by industry sector of employer

\begin{tabular}{lccccc}
\hline & $\begin{array}{c}\mathbf{1 6 - 2 4} \\
\text { year olds } \\
\%\end{array}$ & $\begin{array}{c}\mathbf{1 6 - 1 7} \\
\text { year olds } \\
\%\end{array}$ & $\begin{array}{c}\mathbf{1 8 - 1 9} \\
\text { year olds } \\
\%\end{array}$ & $\begin{array}{c}\mathbf{2 0 - 2 4} \\
\text { year olds } \\
\%\end{array}$ & $\begin{array}{c}\text { Total no. of } \\
\text { employers }\end{array}$ \\
\hline $\begin{array}{l}\text { Manufacturing } \\
\begin{array}{l}\text { Agriculture, mining, utilities \& } \\
\text { construction }\end{array}\end{array}$ & 51 & 14 & 20 & 44 & 183042 \\
$\begin{array}{l}\text { Distribution \& consumer } \\
\text { services }\end{array}$ & 33 & 8 & 12 & 23 & 250929 \\
$\begin{array}{l}\text { Finance \& business services } \\
\text { Transport, public admin \& }\end{array}$ & 54 & 22 & 22 & 43 & 624092 \\
other services & 48 & 4 & 15 & 34 & 559591 \\
TOTAL & 45 & 8 & 20 & 40 & 438002 \\
\hline Base/Coverage: all employers - 4001 & 45 & 12 & 18 & 37 & 2055656 \\
\hline
\end{tabular}


11.1.5 Employers in the North West and in the North East were most likely to employ 16-24 year olds : (64\% and $62 \%$ respectively), whilst employers in London are least likely to do so $(32 \%)$.

Table 90 Employment of 16-24 year olds by Government Office region of employer

\begin{tabular}{lccccc}
\hline & $\begin{array}{c}\mathbf{1 6 - 2 4} \\
\text { year olds } \\
\%\end{array}$ & $\begin{array}{c}\mathbf{1 6 - 1 7} \\
\text { year olds } \\
\%\end{array}$ & $\begin{array}{c}\mathbf{1 8 - 1 9} \\
\text { year olds } \\
\%\end{array}$ & $\begin{array}{c}\mathbf{2 0 - 2 4} \\
\text { year olds } \\
\%\end{array}$ & $\begin{array}{c}\text { Total no. of } \\
\text { employers }\end{array}$ \\
\hline North East & 62 & 17 & 30 & 49 & 71976 \\
North West & 64 & 16 & 20 & 55 & 245697 \\
Yorkshire and the Humber & 53 & 16 & 20 & 47 & 179373 \\
East Midlands & 47 & 18 & 22 & 39 & 161272 \\
West Midlands & 44 & 12 & 22 & 37 & 200189 \\
Eastern & 37 & 12 & 12 & 29 & 233332 \\
London & 32 & 4 & 10 & 30 & 382198 \\
South East & 43 & 11 & 24 & 35 & 366035 \\
South West & 42 & 12 & 16 & 32 & 215584 \\
& & & & & \\
TOTAL & 45 & 12 & 18 & 37 & 2055656 \\
\hline Base/Coverage: all employers - 4001 & & & & &
\end{tabular}




\subsection{Extent to which Qualifications Attained and being Worked towards by 16-24 Year Olds}

11.2.1 Employers employing each of the three age groups discussed were asked what proportion of that age group:

- Had already attained a Level 2 qualification or equivalent

- Was working towards a Level 2 qualification or equivalent

- Had already attained a Level 3 qualification or equivalent

- Was working towards a Level 3 qualification or equivalent

11.2.2 The table below shows the proportion of employees of each age group who have obtained a Level 2 or equivalent qualification. It can be seen that:

- There has been a sizeable increase since the 1999 study in the proportion of 16-17 year olds who have obtained a Level 2 or equivalent qualification.

- There has been a more moderate increase since the 1999 study in the proportion of 18-19 and 20-24 year olds who have obtained the qualification

- In both years, 20-24 year olds are more likely to have obtained the qualification than 18-19 year olds who, in turn, are more likely to have done so than 16-17 year olds.

Table 91 Extent to which Level 2 qualification or equivalent obtained by 16-24 year olds

\begin{tabular}{lcc}
\hline & $\mathbf{1 9 9 9}$ & $\mathbf{2 0 0 0}$ \\
& $\%$ & $\%$ \\
\hline 16-17 year olds & 49 & 61 \\
- any employees already obtained & 36 & 49 \\
- average proportion of employees already obtained & & \\
18-19 year olds & 67 & 73 \\
- any employees already obtained & 48 & 59 \\
- average proportion of employees already obtained & & 75 \\
20-24 year olds & 72 & 61 \\
- any employees already obtained & 55 & \\
- average proportion of employees already obtained & & \\
\hline Base/Coverage: all employing 16-17 year olds - 1239; 18-19 year olds - 2078; 20-24 year olds - 3045
\end{tabular}


11.2.3 The table below shows the proportion of employees of each age group who are working towards a Level 2 or equivalent qualification. It can be seen that:

- There has been no change since the 1999 study in the proportion of 16-17 and 2024 year olds who are working towards a Level 2 or equivalent qualification

- There has been a decrease since the 1999 study in the proportion of 18-19 year olds who are working towards the qualification

- In both years, 16-17 year olds are more likely to be working towards the qualification than 18-19 year olds who, in turn, are more likely to be doing so than 20-24 year olds

Table 92 Extent to which Level 2 qualification or equivalent being worked towards by 16-24 year olds

\begin{tabular}{|c|c|c|}
\hline & $\begin{array}{c}1999 \\
\%\end{array}$ & $\begin{array}{c}2000 \\
\%\end{array}$ \\
\hline \multicolumn{3}{|l|}{$16-17$ year olds } \\
\hline - any employees working towards & 41 & 43 \\
\hline - average proportion of employees working towards & 27 & 32 \\
\hline \multicolumn{3}{|l|}{$18-19$ year olds } \\
\hline - any employees working towards & 27 & 20 \\
\hline - average proportion of employees working towards & 17 & 10 \\
\hline 20-24 year olds & & \\
\hline $\begin{array}{l}\text { - any employees working towards } \\
\text { - average proportion of employees working towards }\end{array}$ & $\begin{array}{c}12 \\
5\end{array}$ & $\begin{array}{c}13 \\
6\end{array}$ \\
\hline
\end{tabular}

11.2.4 The table below shows the proportion of employees of each age group who have obtained a Level 3 or equivalent qualification. It can be seen that:

- There has been no change since the 1999 study in the proportion of 16-17 year olds who have obtained a Level 3 or equivalent qualification

- There has been an increase since the 1999 study in the proportion of 18-19 and 2024 year olds who have obtained the qualification

- In both years, 20-24 year olds are more likely to have obtained the qualification than 18-19 year olds who, in turn, are more likely to have done so than 16-17 year olds.

Table 93 Extent to which Level 3 qualification or equivalent obtained by 16-24 year olds

\begin{tabular}{lcc}
\hline & $\begin{array}{c}\mathbf{1 9 9 9} \\
\%\end{array}$ & $\begin{array}{c}\mathbf{2 0 0 0} \\
\%\end{array}$ \\
\hline 16-17 year olds & 10 & 12 \\
- any employees already obtained & 5 & 5 \\
- average proportion of employees already obtained & & 34 \\
18-19 year olds & 29 & 23 \\
- any employees already obtained & 16 & 51 \\
- average proportion of employees already obtained & & 37 \\
20-24 year olds & 47 & 32 \\
- any employees already obtained & & 32 \\
- average proportion of employees already obtained & Base/Coverage: all employing 16-17 year olds - 1239; 18-19 year olds - 2078; 20-24 year olds - 3045
\end{tabular}


11.2.5 The table below shows the proportion of employees of each age group who are working towards a Level 3 or equivalent qualification. It can be seen that:

- There has been an increase since the 1999 study in the proportion of 16-17 year olds who are working towards a Level 3 or equivalent qualification

- There has been no change since the 1999 study in the proportion of 18-19 and 2024 year olds who are working towards the qualification

- In both years, 16-17 year olds are more likely to be working towards the qualification than 18-19 year olds who, in turn, are more likely to be doing so than 20-24 year olds.

Table 94 Extent to which Level 3 qualification or equivalent being worked towards by 16-24 year olds

\begin{tabular}{lcc}
\hline & $\begin{array}{c}1999 \\
\%\end{array}$ & $\begin{array}{c}2000 \\
\%\end{array}$ \\
\hline 16-17 year olds & 29 & 43 \\
- any employees working towards & 20 & 34 \\
- average proportion of employees working towards & & 28 \\
18-19 year olds & 26 & 18 \\
- any employees working towards & 16 & \\
- average proportion of employees working towards & & 13 \\
20-24 year olds & 13 & 7 \\
- any employees working towards & 7 & average proportion of employees working towards \\
- aase/Coverage: all employing 16-17 year olds - 1239; 18-19 year olds - 2078; 20-24 year olds - 3045
\end{tabular}


Chapter 12

Comparison with

Skill Needs in Britain Surveys 


\section{Comparison with Skill Needs in Britain Surveys}

\subsection{Introduction}

12.1.1 As previously stated, the 2000 and 1999 Learning and Training at Work studies covered employers in England in all business sectors having 1 or more employees. The SNIB surveys covered employers in Great Britain in all business sectors, except agriculture, hunting, forestry and fishing, having 25 or more employees.

12.1.2 We have reanalysed the 1997 and 1998 SNIB surveys and conducted further analysis on the Learning and Training at Work studies to provide comparable results over the past four years. These results relate to employers in England in all business sectors, except agriculture, hunting, forestry and fishing, with 25 or more employees. The figures for 1999 and 2000 are often substantially different to the figures that have been reported earlier in this report, as the large number of small employers that dominated the full LTW weighted results are excluded here.

\subsection{Changing Level of Skill Needs}

12.2.1 Over the past four years around $70 \%$ of employers believed the skills needed by their average employee in order to ensure the effective operation of their business have increased.

\section{Fig 11 Changing skill needs in average employee}

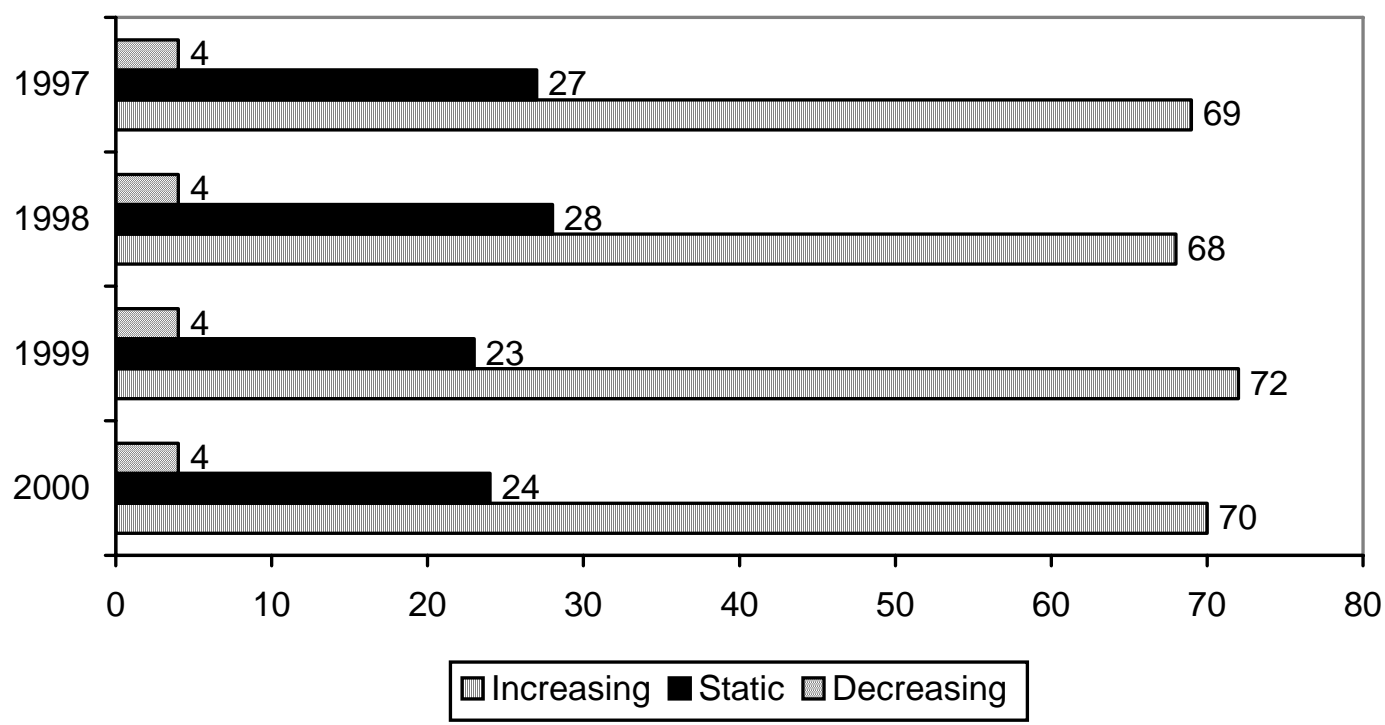

Base/Coverage: all employers 
12.2.2 There has been little change over time in the proportion of smaller and medium sized employers who felt the skill needs of their average employee were increasing: there has been an increase since the 1998 study in the proportion of employers with 200 or more employees who feel this way.

Table 95 Increasing skill needs in average employee by size of employer

\begin{tabular}{lcccc}
\hline & $\mathbf{1 9 9 7}$ & $\mathbf{1 9 9 8}$ & $\mathbf{1 9 9 9}$ & $\mathbf{2 0 0 0}$ \\
& $\%$ & $\%$ & $\%$ & $\%$ \\
\hline $25-49$ & 68 & 66 & 71 & 68 \\
$50-99$ & 68 & 70 & 71 & 70 \\
$100-199$ & 71 & 70 & 72 & 71 \\
$200-499$ & 74 & 72 & 71 & 76 \\
$500+$ & 80 & 74 & 77 & 84 \\
TOTAL & 69 & 68 & 72 & 70 \\
\hline Base/Coverage: all employers & & & &
\end{tabular}

Base/Coverage: all employers

12.2.3 The table below shows the proportion of employers in each industry sector who stated that the skills required of an average employee were increasing.

Table 96 Increasing skill needs in average employee by industry sector of employer

\begin{tabular}{lcccc}
\hline & $\mathbf{1 9 9 7}$ & $\mathbf{1 9 9 8}$ & $\mathbf{1 9 9 9}$ & $\mathbf{2 0 0 0}$ \\
& $\%$ & $\%$ & $\%$ & $\%$ \\
\hline Manufacturing & 62 & 63 & 59 & 56 \\
Mining, utilities, construction & 67 & 57 & 67 & 69 \\
Distribution \& consumer services & 68 & 60 & 69 & 65 \\
Finance \& business services & 74 & 69 & 74 & 75 \\
Transport, public administration \& & 71 & 75 & 78 & 77 \\
other services & & & & \\
TOTAL & 69 & 68 & 72 & 70 \\
\hline
\end{tabular}

Base/Coverage: all employers 
12.2.4 As one can see from the following table, there has been no consistent pattern over time in the proportion of employers in each region finding that the skills required from the average employee are increasing.

Table 97 Increasing skill needs in average employee by Government Office region of employer

\begin{tabular}{lcccc}
\hline & $\mathbf{1 9 9 7}$ & $\mathbf{1 9 9 8}$ & $\mathbf{1 9 9 9}$ & $\mathbf{2 0 0 0}$ \\
& $\%$ & $\%$ & $\%$ & $\%$ \\
\hline North East & 71 & 73 & 72 & 67 \\
North West & 63 & 66 & 74 & 67 \\
Yorkshire and the Humber & 65 & 61 & 67 & 73 \\
East Midlands & 68 & 60 & 67 & 64 \\
West Midlands & 67 & 68 & 66 & 65 \\
Eastern & 72 & 67 & 73 & 73 \\
London & 72 & 75 & 73 & 76 \\
South East & 74 & 67 & 76 & 68 \\
South West & 69 & 74 & 71 & 72 \\
TOTAL & 69 & 68 & 72 & 70 \\
\hline
\end{tabular}

\subsection{Recruitment Difficulties}

12.3.1 The proportion of employers experiencing a hard-to-fill vacancy at the time of interview increased between 1997 and 1998, remained constant between 1998 and 1999 and has increased over the past year

Table 98 Existence of hard-to-fill vacancies at time of interview

\begin{tabular}{lcccc}
\hline & 1997 & 1998 & 1999 & 2000 \\
\hline \% of employers with hard-to-fill vacancy & 18 & 24 & 23 & 30 \\
\hline Base/Coverage: all employers & & & & \\
\hline
\end{tabular}

12.3.2 In general, in all four years, the proportion of employers with a hard-to-fill vacancy at the time of interview increases with increasing size of employer, though not in a regular manner. This is what one could expect intuitively as larger employers are more likely to have a hardto-fill vacancy merely through having a greater number of employees. There has been a notable increase since the 1999 study in the proportion of employers with 25-49 employees who reported a hard-to-fill vacancy in the 2000 study.

Table 99 Existence of hard-to-fill vacancies by size of employer

\begin{tabular}{lcccc}
\hline & $\mathbf{1 9 9 7}$ & $\mathbf{1 9 9 8}$ & $\mathbf{1 9 9 9}$ & $\mathbf{2 0 0 0}$ \\
& $\%$ & $\%$ & $\%$ & $\%$ \\
\hline $25-49$ & 16 & 20 & 17 & 27 \\
$50-99$ & 19 & 25 & 29 & 32 \\
$100-199$ & 19 & 28 & 26 & 35 \\
$200-499$ & 23 & 27 & 29 & 32 \\
$500+$ & 28 & 33 & 34 & 42 \\
TOTAL & 18 & 24 & 23 & 30 \\
\hline Base/Coverage: all employers & & & &
\end{tabular}


12.3.3 The proportion of employers in each industry sector with a hard-to-fill vacancy at the time of interview was as follows:

Table 100 Existence of hard-to-fill vacancies by industry sector of employer

\begin{tabular}{lcccc}
\hline & $\mathbf{1 9 9 7}$ & $\mathbf{1 9 9 8}$ & $\mathbf{1 9 9 9}$ & $\mathbf{2 0 0 0}$ \\
& $\%$ & $\%$ & $\%$ & $\%$ \\
\hline Manufacturing & 15 & 19 & 20 & 26 \\
Mining, utilities, construction & 13 & 11 & 21 & 26 \\
Distribution \& consumer services & 24 & 26 & 28 & 36 \\
Finance \& business services & 22 & 23 & 19 & 28 \\
Transport, public administration \& & 15 & 26 & 24 & 30 \\
other services & & & & \\
TOTAL & 18 & 24 & 23 & 30 \\
\hline
\end{tabular}

Base/Coverage: all employers

12.3.4 The proportion of employers in each region reporting a hard-to-fill vacancy at the time of interview was as follows:

Table 101 Existence of hard-to-fill vacancies by Government Office region of employer

\begin{tabular}{lcccc}
\hline & $\mathbf{1 9 9 7}$ & $\mathbf{1 9 9 8}$ & $\mathbf{1 9 9 9}$ & $\mathbf{2 0 0 0}$ \\
& $\%$ & $\%$ & $\%$ & $\%$ \\
\hline North East & 14 & 26 & 13 & 25 \\
North West & 14 & 20 & 20 & 24 \\
Yorkshire and the Humber & 14 & 18 & 17 & 26 \\
East Midlands & 19 & 27 & 22 & 33 \\
West Midlands & 18 & 23 & 24 & 24 \\
Eastern & 21 & 22 & 29 & 30 \\
London & 20 & 26 & 22 & 30 \\
South East & 24 & 25 & 29 & 37 \\
South West & 16 & 26 & 25 & 37 \\
& & & & 30 \\
TOTAL & 18 & 24 & 23 & 37
\end{tabular}

Base/Coverage: all employers 


\subsection{Learning Opportunities}

12.4.1 The proportion of employers offering one or more of a number of learning opportunities to employees has increased year on year over the last three surveys. (Data are not available from the 1997 study.)

All individual types of learning opportunity with the exception of basic numeracy and literacy are now being offered by more employers.

Table 102 Learning Opportunities offered

\begin{tabular}{lccc}
\hline & $\mathbf{1 9 9 8}$ & $\mathbf{1 9 9 9}$ & $\mathbf{2 0 0 0}$ \\
& $\%$ & $\%$ & 86 \\
\hline Any & 67 & 75 & 71 \\
Information technology & 50 & 61 & 64 \\
Working with others & 44 & 49 & 60 \\
Communication & 42 & 47 & 63 \\
Managing own development & 41 & 51 & 54 \\
Problem solving & 34 & 42 & 27 \\
Application of numbers & 17 & 26 & 17 \\
Basic numeracy & $16]$ & 17 & 17 \\
Basic literacy & & 18 &
\end{tabular}

Base/Coverage: all employers

12.4.2 Learning opportunities were more likely to be offered by larger employers. There has been a large increase since the 1999 study in the proportion of employers with 25-49 employees offering learning opportunities.

Table 103 Learning opportunities offered by size of employer

\begin{tabular}{lccc}
\hline & $\mathbf{1 9 9 8}$ & $\mathbf{1 9 9 9}$ & $\mathbf{2 0 0 0}$ \\
\hline $25-49$ & $\%$ & $\%$ & $\%$ \\
$50-99$ & 64 & 66 & 82 \\
$100-199$ & 64 & 80 & 88 \\
$200-499$ & 75 & 84 & 91 \\
$500+$ & 81 & 91 & 96 \\
TOTAL & 93 & 96 & 99 \\
\hline
\end{tabular}


12.4.3 Learning opportunities were offered by a higher proportion of those in service orientated sectors than those in production sectors, although it is in the latter that the larger relative increase has occurred since the 1999 study.

Table 104 Learning opportunities offered by industry sector of employer

\begin{tabular}{lccc}
\hline & $\mathbf{1 9 9 8}$ & $\mathbf{1 9 9 9}$ & $\mathbf{2 0 0 0}$ \\
& $\%$ & $\%$ & $\%$ \\
\hline Manufacturing & 60 & 64 & 81 \\
Mining, utilities, construction & 55 & 65 & 80 \\
Distribution \& consumer services & 67 & 75 & 88 \\
Finance \& business services & 68 & 81 & 91 \\
Transport, public administration \& & 71 & 79 & 87 \\
other services & & & \\
TOTAL & 67 & 75 & 86 \\
\hline Base/Coverage: all employers & & &
\end{tabular}

12.4.4 The proportion of employers in each region offering one or more of the learning opportunities was as follows:

Table 105 Learning opportunities offered by Government Office region of employer

\begin{tabular}{lccc}
\hline & $\mathbf{1 9 9 8}$ & $\mathbf{1 9 9 9}$ & $\mathbf{2 0 0 0}$ \\
& $\%$ & $\%$ & $\%$ \\
\hline North East & 60 & 79 & 85 \\
North West & 68 & 73 & 92 \\
Yorkshire and the Humber & 66 & 70 & 83 \\
East Midlands & 63 & 69 & 82 \\
West Midlands & 69 & 73 & 83 \\
Eastern & 69 & 72 & 89 \\
London & 66 & 77 & 89 \\
South East & 71 & 78 & 85 \\
South West & 66 & 84 & 85 \\
TOTAL & & & \\
\hline
\end{tabular}

Base/Coverage: all employers

12.4.5 The proportion of employers with staff association or trade union representation has varied as follows: $28 \%$ in the 1998 study, $37 \%$ in the 1999 study and $32 \%$ in the 2000 study (no data from the 1997 study are available). 


\subsection{Provision of Off-the-Job Training}

12.5.1 Information on the provision of off-the-job training collected in the 1999 and 2000 studies may not be strictly comparable with that obtained in the 1997 and 1998 surveys due to a change in question wording that may have led to 1999 and 2000 figures being underestimates.

12.5.2 The proportion of employers who reported having provided off-the-job training over the previous 12 months remained constant between the 1997 and the 1998 studies; dropped between the 1998 and 1999 studies and in the most recent study, has returned to the 1997 level.

Table 106 Employers providing off-the-job training

\begin{tabular}{lcccc}
\hline & 1997 & 1998 & 1999 & 2000 \\
\hline$\%$ of employers & 82 & 83 & 75 & 81 \\
\hline Base/Coverage: all employers & & & & \\
\hline
\end{tabular}

12.5.3 The proportion of employers providing off-the-job training over the previous 12 months, generally speaking, increases with increasing size of employer. There has been an increase since the 1999 study in the proportion of employers of all sizes offering off-the-job training.

Table 107 Employers providing off-the-job training by size of employer

\begin{tabular}{lcccc}
\hline & $\mathbf{1 9 9 7}$ & $\mathbf{1 9 9 8}$ & $\mathbf{1 9 9 9}$ & $\mathbf{2 0 0 0}$ \\
& $\%$ & $\%$ & $\%$ & $\%$ \\
\hline $25-49$ & 80 & 80 & 69 & 74 \\
$50-99$ & 82 & 84 & 77 & 82 \\
$100-199$ & 87 & 89 & 82 & 92 \\
$200-499$ & 91 & 91 & 89 & 96 \\
$500+$ & 90 & 92 & 91 & 98 \\
TOTAL & & & & \\
\hline Base/Coverage: all employers & 82 & 83 & 75 & 81 \\
\hline
\end{tabular}

12.5.4 The proportion of employers in each industry sector who have provided off-the-job training over the previous year is shown below.

Table 108 Employers providing off-the-job training by industry sector of employer

\begin{tabular}{lcccc}
\hline & $\mathbf{1 9 9 7}$ & $\mathbf{1 9 9 8}$ & $\mathbf{1 9 9 9}$ & $\mathbf{2 0 0 0}$ \\
& $\%$ & $\%$ & $\%$ & $\%$ \\
\hline Manufacturing & 77 & 78 & 72 & 79 \\
Mining, utilities, construction & 78 & 76 & 81 & 87 \\
Distribution \& consumer services & 81 & 79 & 65 & 75 \\
Finance \& business services & 85 & 79 & 76 & 83 \\
Transport, public administration \& & 85 & 90 & 82 & 84 \\
other services & & & & \\
TOTAL & 82 & 83 & 75 & 81 \\
\hline Base/Coverage: all employers & & &
\end{tabular}


12.5.5 The provision of off-the-job training by employers over the previous year has varied by region as shown in the table below.

Table 109 Employers funding or arranging off-the-job training by Government Office region of employer

\begin{tabular}{lcccc}
\hline & $\mathbf{1 9 9 7}$ & $\mathbf{1 9 9 8}$ & $\mathbf{1 9 9 9}$ & $\mathbf{2 0 0 0}$ \\
& $\%$ & $\%$ & $\%$ & $\%$ \\
\hline North East & 84 & 86 & 73 & 88 \\
North West & 78 & 83 & 76 & 81 \\
Yorkshire and the Humber & 84 & 85 & 74 & 79 \\
East Midlands & 78 & 81 & 74 & 80 \\
West Midlands & 89 & 84 & 70 & 71 \\
Eastern & 83 & 83 & 79 & 86 \\
London & 82 & 83 & 72 & 85 \\
South East & 82 & 83 & 78 & 79 \\
South West & 81 & 81 & 80 & 82 \\
TOTAL & 82 & 83 & 75 & 81 \\
\hline
\end{tabular}

Base/Coverage: all employers

12.5.6 The proportion of employees who have received off-the-job training declined between the 1997 and 1999 studies, but has increased slightly in the 2000 study.

Table 110 Employees receiving off-the-job training

\begin{tabular}{lcccc}
\hline & 1997 & 1998 & 1999 & 2000 \\
\hline$\%$ of employees & 41 & 38 & 24 & 28 \\
\hline $\begin{array}{l}\text { Base/Coverage: all employers who had provided off-the-job training over the previous 12 } \\
\text { months }\end{array}$ & & & &
\end{tabular}

12.5.7 The proportion of employees receiving off-the-job training varied by establishment size as shown below. The most notable trend over time is the consistent decline in the proportion of employees in large establishments receiving off-the-job training.

Table 111 Proportion of employees receiving off-the-job training by size of employer

\begin{tabular}{lcccc}
\hline & $\mathbf{1 9 9 7}$ & $\mathbf{1 9 9 8}$ & $\mathbf{1 9 9 9}$ & $\mathbf{2 0 0 0}$ \\
& $\%$ & $\%$ & $\%$ & $\%$ \\
\hline $25-49$ & 39 & 42 & ] 29 & 31 \\
$50-99$ & 39 & 41 & 25 & 36 \\
$100-199$ & 39 & 41 & 25 & 34 \\
$200-499$ & 45 & 36 & 25 & 16 \\
$500+$ & 43 & 34 & 20 & 28 \\
TOTAL & 41 & 38 & 24 & 28 \\
Base/Coverage: all employers who had provided off-the-job training over the previous 12 months
\end{tabular}


12.5.8 There has been an increase since the 1999 study in the proportion of employees receiving off-the-job training, except amongst those in the transport, public administration and other services sector where the figure has remained constant.

Table 112 Proportion of employees receiving off-the-job training by industry sector of employer

\begin{tabular}{lcccc}
\hline & $\mathbf{1 9 9 7}$ & $\mathbf{1 9 9 8}$ & $\mathbf{1 9 9 9}$ & $\mathbf{2 0 0 0}$ \\
& $\%$ & $\%$ & $\%$ & $\%$ \\
\hline Manufacturing & 33 & 33 & 19 & 23 \\
Mining, utilities, construction & 41 & 29 & 28 & 35 \\
Distribution \& consumer services & 45 & 41 & 19 & 31 \\
Finance \& business services & 43 & 40 & 25 & 31 \\
Transport, public administration \& & 44 & 41 & 28 & 28 \\
other services & & & & \\
TOTAL & 41 & 38 & 24 & 28 \\
Base/Coverage: all employers who had provided off-the-job training over the previous 12 months
\end{tabular}

12.5.9 The proportion of employees in each region who had received off-the-job training in the previous 12 months was as follows:

Table 113 Proportion of employees receiving off-the-job training by Government Office region of employer

\begin{tabular}{lcccc}
\hline & $\mathbf{1 9 9 7}$ & $\mathbf{1 9 9 8}$ & $\mathbf{1 9 9 9}$ & $\mathbf{2 0 0 0}$ \\
& $\%$ & $\%$ & $\%$ & $\%$ \\
\hline North East & 41 & 35 & 24 & 30 \\
North West & 38 & 39 & 25 & 29 \\
Yorkshire and the Humber & 40 & 40 & 23 & 26 \\
East Midlands & 41 & 36 & 20 & 26 \\
West Midlands & 41 & 36 & 16 & 28 \\
Eastern & 40 & 38 & 21 & 33 \\
London & 42 & 43 & 25 & 30 \\
South East & 46 & 39 & 27 & 25 \\
South West & 40 & 32 & 31 & 29 \\
& \multicolumn{4}{c}{$\mathbf{n}$} \\
TOTAL & 41 & 38 & 24 & 28 \\
\hline Base/Coverage: all employers who had provided off-the-job training over the previous 12 months & \multicolumn{4}{l}{}
\end{tabular}

12.5.10 The average number of days off-the-job training received per employee receiving off-the-job training increased from 1997 to 1999 and decreased in the most recent study.

Table 114 Amount of off-the-job training received

\begin{tabular}{lcccc}
\hline & 1997 & 1998 & 1999 & 2000 \\
\hline $\begin{array}{l}\text { Average number of days per employee } \\
\text { Receiving training }\end{array}$ & 7.9 & 8.5 & 9.4 & 8.1 \\
\hline Base/Coverage: all employers who had provided off-the-job training over the previous 12 months
\end{tabular}


12.5.11 The average number of days training provided by size of employer is shown in the table below.

Table 115 Average number of training days per employee trained by size of employer

\begin{tabular}{lcccc}
\hline & $\mathbf{1 9 9 7}$ & $\mathbf{1 9 9 8}$ & $\mathbf{1 9 9 9}$ & $\mathbf{2 0 0 0}$ \\
\hline $25-49$ & 6.9 & 7.9 & ] 9.4 & 7.9 \\
$50-99$ & 7.4 & 8.6 & 9.4 \\
$100-199$ & 7.6 & 7.0 & 9.4 & 8.6 \\
$200-499$ & 7.8 & 8.7 & 9.4 & 6.9 \\
$500+$ & 9.1 & 9.8 & 8.6 & 6.5 \\
& & & & \\
TOTAL & 7.9 & 8.5 & 9.4 & 8.1 \\
\hline Base/Coverage: all employers who had provided off-the-job training over the previous 12 months
\end{tabular}

Base/Coverage: all employers who had provided off-the-job training over the previous 12 months

12.5.12 The average number of training days received by employees in various industry sectors is shown in the table below.

Table 116 Average number of training days per employee trained by industry sector of employer

\begin{tabular}{|c|c|c|c|c|}
\hline & 1997 & 1998 & 1999 & 2000 \\
\hline Manufacturing & 8.1 & 8.2 & 12.2 & 8.9 \\
\hline Mining, utilities, construction & 7.4 & 8.1 & 10.7 & 12.2 \\
\hline Distribution \& consumer services & 7.5 & 7.7 & 9.1 & 7.1 \\
\hline Finance \& business services & 7.7 & 8.8 & 9.0 & 7.3 \\
\hline $\begin{array}{l}\text { Transport, public administration \& } \\
\text { other services }\end{array}$ & 8.1 & 8.8 & 8.3 & 8.0 \\
\hline TOTAL & 7.9 & 8.5 & 9.4 & 8.1 \\
\hline
\end{tabular}

Base/Coverage: all employers who had provided off-the-job training over the previous 12 months

12.5.13 The average number of days off-the-job training received by employees in each region was as follows:

Table 117 Average number of training days per employee trained by Government Office region of employer

\begin{tabular}{lcccc}
\hline & $\mathbf{1 9 9 7}$ & $\mathbf{1 9 9 8}$ & $\mathbf{1 9 9 9}$ & $\mathbf{2 0 0 0}$ \\
\hline North East & 8.6 & 9.0 & 9.4 & 5.5 \\
North West & 7.7 & 10.1 & 11.6 & 9.0 \\
Yorkshire and the Humber & 7.1 & 8.9 & 9.9 & 7.6 \\
East Midlands & 7.9 & 8.6 & 10.8 & 8.8 \\
West Midlands & 7.6 & 7.7 & 8.3 & 7.8 \\
Eastern & 7.6 & 8.4 & 8.5 & 7.4 \\
London & 8.3 & 7.5 & 9.0 & 7.6 \\
South East & 7.5 & 8.1 & 8.5 & 9.1 \\
South West & 9.1 & 8.9 & 8.9 & 8.3 \\
TOTAL & \multicolumn{4}{c}{9.4} \\
Base/Coverage: all employers who had provided off-the-job training over the previous 12 months
\end{tabular}




\subsection{Management and Delivery of Off-the-Job Training}

12.6.1 The proportion of employers reporting that they had a business plan has increased slightly since the 1999 study.

The proportion reporting the existence of a training plan, training budget and human resources plan has remained at a similar level to that reported in the 1999 study.

Table 118 Existence of plans and budgets

\begin{tabular}{|c|c|c|c|c|}
\hline & $\begin{array}{c}1997 \\
\% \\
\end{array}$ & $\begin{array}{c}1998 \\
\% \\
\end{array}$ & $\begin{array}{c}1999 \\
\% \\
\end{array}$ & $\begin{array}{c}2000 \\
\% \\
\end{array}$ \\
\hline Business plan & 79 & 79 & 78 & 82 \\
\hline - as written statement & 63 & 63 & 62 & 60 \\
\hline - less formally & 16 & 16 & 17 & 22 \\
\hline Training plan & 65 & 65 & 72 & 72 \\
\hline - as written statement & 49 & 49 & 55 & 53 \\
\hline - less formally & 16 & 15 & 17 & 18 \\
\hline Training budget & 63 & 63 & 67 & 69 \\
\hline - as written statement & 50 & 49 & 53 & 54 \\
\hline - less formally & 13 & 12 & 13 & 15 \\
\hline Human resources plan & 52 & 53 & 55 & 54 \\
\hline - as written statement & 41 & 39 & 40 & 38 \\
\hline - less formally & 11 & 14 & 15 & 16 \\
\hline
\end{tabular}

12.6.2 The existence of plans and budgets is more common in larger establishments than in smaller ones.

12.6.3 There is no consistent pattern over time by industry sector or region in the existence of plans and budgets.

12.6.4 The resources within the organisation reported as being allocated to off-the-job training have increased continuously since the 1997 study.

Table 119 Allocation of staff and resources to off-the-job training

\begin{tabular}{lcccc}
\hline & 1997 & 1998 & 1999 & 2000 \\
\hline $\begin{array}{l}\text { \% having senior management responsible } \\
\text { for training }\end{array}$ & 75 & 77 & 80 & 81 \\
$\begin{array}{l}\text { \% having a separate training facility } \\
\text { \% having staff to design and teach training }\end{array}$ & 30 & 35 & 37 & 38 \\
courses & n/a & 39 & 46 & 50 \\
\hline
\end{tabular}

Base/Coverage: all employers who had provided off-the-job training over the previous 12 months 
12.6.5 Larger employers were more likely than smaller to have senior management responsible for training, a separate training facility and to have staff to design and teach training courses.

12.6.6 Generally speaking, employers in service sectors were more likely to dedicate staff and resources to off-the-job training than those in the manufacturing and in the mining, utilities and construction sectors.

12.6.7 There is no consistent pattern by region in the allocation of resources to off-the-job training.

12.6.8 The types of off-the-job training provided have varied over time as shown below:

Table 120 Types of off-the-job training provided

\begin{tabular}{lcccc}
\hline & $\mathbf{1 9 9 7}$ & $\mathbf{1 9 9 8}$ & $\mathbf{1 9 9 9}$ & $\mathbf{2 0 0 0}$ \\
\hline Job specific & $\mathrm{n} / \mathrm{a}$ & 78 & 85 & 85 \\
Health and safety & 83 & 80 & 87 & 90 \\
Training in new technology & 60 & 60 & 71 & 70 \\
Induction training & 75 & 65 & 78 & 81 \\
Management training & 58 & 58 & 65 & 66 \\
Supervisory training & 56 & 52 & 60 & 63 \\
Training in foreign languages & 6 & 7 & 11 & 9 \\
\hline
\end{tabular}

Base/Coverage: all employers who had provided off-the-job training over the previous 12 months

12.6.9 The provision of all types of training increases with increasing employer size.

12.6.10 There is no consistent pattern over time by industry sector or region in the provision of different types of training.

12.6.11 The proportion of employers providing off-the-job training who stated that at least some of the training was leading to formal qualifications was $65 \%$ in the 1997 and 1998 studies declined a little to $62 \%$ in the 1999 study, and increased to $67 \%$ in the most recent study.

12.6.12 A higher proportion of larger employers offered training leading to formal qualifications in all four studies. There has been an increase since the 1999 study in the proportion of smaller and medium sized employers who are doing so, whilst amongst larger employers the proportion has remained static or declined slightly.

Table 121 Training leading to formal qualifications by size of employer

\begin{tabular}{lcccc}
\hline & $\mathbf{1 9 9 7}$ & $\mathbf{1 9 9 8}$ & $\mathbf{1 9 9 9}$ & $\mathbf{2 0 0 0}$ \\
& $\%$ & $\%$ & $\%$ & $\%$ \\
\hline $25-49$ & 60 & 62 & 55 & 60 \\
$50-99$ & 64 & 62 & 60 & 68 \\
$100-199$ & 74 & 71 & 67 & 73 \\
$200-499$ & 83 & 78 & 85 & 82 \\
$500+$ & 90 & 88 & 90 & 90 \\
& & & & \\
TOTAL & 65 & 65 & 62 & 67 \\
\hline
\end{tabular}

Base/Coverage: all employers who had provided off-the-job training over the previous 12 months 
12.6.13 The proportion of employers in each industry sector providing off-the-job training leading to formal qualifications was as follows. There has been a noticeable increase since the 1999 study in the proportion of employers in the distribution and consumer services sector who are doing so.

Table 122 Training leading to formal qualifications by industry sector of employer

\begin{tabular}{lcccc}
\hline & $\mathbf{1 9 9 7}$ & $\mathbf{1 9 9 8}$ & $\mathbf{1 9 9 9}$ & $\mathbf{2 0 0 0}$ \\
& $\%$ & $\%$ & $\%$ & $\%$ \\
\hline Manufacturing & 64 & 60 & 69 & 69 \\
Mining, utilities, construction & 65 & 78 & 63 & 70 \\
Distribution \& consumer services & 58 & 64 & 46 & 64 \\
Finance \& business services & 63 & 59 & 66 & 66 \\
$\begin{array}{l}\text { Transport, public administration \& } \\
\text { other services }\end{array}$ & 71 & 68 & 64 & 68 \\
TOTAL & 65 & 65 & 62 & 67 \\
\hline Base/Coverage: all employers who had provided off-the-job training over the previous 12 months
\end{tabular}

12.6.14 The proportion of employers in each region funding or arranging off-the-job training leading for formal qualifications was as follows:

Table 123 Training leading to formal qualifications by Government Office region of employer

\begin{tabular}{lcccc}
\hline & $\mathbf{1 9 9 7}$ & $\mathbf{1 9 9 8}$ & $\mathbf{1 9 9 9}$ & $\mathbf{2 0 0 0}$ \\
& $\%$ & $\%$ & $\%$ & $\%$ \\
\hline North East & 71 & 73 & 60 & 62 \\
North West & 74 & 68 & 65 & 69 \\
Yorkshire and the Humber & 72 & 66 & 62 & 74 \\
East Midlands & 60 & 66 & 66 & 61 \\
West Midlands & 73 & 66 & 68 & 69 \\
Eastern & 58 & 68 & 59 & 66 \\
London & 54 & 60 & 55 & 63 \\
South East & 71 & 63 & 56 & 69 \\
South West & 58 & 62 & 70 & 69 \\
TOTAL & 65 & 65 & 62 & 67 \\
\hline Base/Coverage: all employers who had provided off-the-job training over the previous 12 months
\end{tabular}

\subsection{Provision of On-the-Job Training}

12.7.1 The proportion of employers in the 1998 study reporting that they had carried out on-the-job training in the previous 12 months was $90 \%$. In the 1999 study it was $86 \%$. In the 2000 study it was again 90\% (no data are available from the 1997 study).

12.7.2 In all three studies on-the-job training was most commonly provided by a line manager or by other experienced staff in the company. 
12.7.3 Provision of on-the-job training does not vary widely by size of employer. There has been an increase since the 1999 study in the proportion of smaller and medium sized employers offering on-the-job training. The proportion of larger employers doing so has remained static or declined slightly.

Table 124 Provision of on-the-job training by size of employer

\begin{tabular}{lccc}
\hline & $\mathbf{1 9 9 8}$ & $\mathbf{1 9 9 9}$ & $\mathbf{2 0 0 0}$ \\
$\%$ & $\%$ & $\%$ \\
\hline $25-49$ & 90 & 82 & 87 \\
$50-99$ & 89 & 89 & 91 \\
$100-199$ & 93 & 88 & 94 \\
$200-499$ & 95 & 94 & 93 \\
$500+$ & 95 & 94 & 92 \\
TOTAL & & & \\
\hline
\end{tabular}

Base/Coverage: all employers

12.7.4 The proportion of employers in each industry sector who had carried out on-the-job training in the past 12 months is shown below.

Table 125 Provision of on-the-job training by industry sector of employer

\begin{tabular}{lccc}
\hline & $\mathbf{1 9 9 8}$ & $\mathbf{1 9 9 9}$ & $\mathbf{2 0 0 0}$ \\
& $\%$ & $\%$ & $\%$ \\
\hline Manufacturing & 90 & 86 & 87 \\
Mining, utilities, construction & 85 & 76 & 78 \\
Distribution \& consumer services & 95 & 91 & 95 \\
Finance \& business services & 88 & 87 & 87 \\
Transport, public administration \& & 90 & 84 & 91 \\
other services & & & \\
TOTAL & 90 & 86 & 90 \\
\hline Base/Coverage: all employers & & &
\end{tabular}

12.7.5 The proportion of employers in each region who had carried out on-the-job training in the past 12 months is shown below.

Table 126 Provision of on-the-job training by Government Office region of employer

\begin{tabular}{lccc}
\hline & $\mathbf{1 9 9 8}$ & $\mathbf{1 9 9 9}$ & $\mathbf{2 0 0 0}$ \\
& $\%$ & $\%$ & $\%$ \\
\hline North East & 89 & 85 & 91 \\
North West & 90 & 88 & 92 \\
Yorkshire and the Humber & 91 & 89 & 91 \\
East Midlands & 89 & 88 & 89 \\
West Midlands & 92 & 81 & 89 \\
Eastern & 91 & 88 & 89 \\
London & 91 & 84 & 89 \\
South East & 89 & 86 & 92 \\
South West & 91 & 88 & 88 \\
TOTAL & & & \\
\hline Bath & 90 & 86 & 90 \\
\hline
\end{tabular}




\subsection{Awareness of, and Involvement with, Training Initiatives}

12.8.1 The proportion of employers aware of a number of training initiatives has varied as follows over time:

Awareness has tended to increase over time, with the exception of National Traineeships where there has been no consistent pattern.

Table 127 Awareness of training initiatives

\begin{tabular}{lcccc}
\hline & $\mathbf{1 9 9 7}$ & $\mathbf{1 9 9 8}$ & $\mathbf{1 9 9 9}$ & $\mathbf{2 0 0 0}$ \\
& $\%$ & $\%$ & $\%$ & $\%$ \\
\hline NVQs/SVQs & 96 & 97 & 96 & 99 \\
Modern Apprenticeships** & 76 & 73 & 72 & 78 \\
New Deal for Young People & $\mathrm{n} / \mathrm{a}$ & & 66 & 58 \\
New Deal for Long Term Unemployed & $\mathrm{n} / \mathrm{a}$ & $57] \star$ & 61 & 58 \\
$\quad$ People & 65 & 59 & 61 & 67 \\
National Record of Achievement & $\mathrm{n} / \mathrm{a}$ & 24 & 48 & 38 \\
National Traineeships*** & &
\end{tabular}

Base/Coverage: all employers

*asked as "New Deal" in the 1998 study

**recently relaunched as Advanced Modern Apprenticeships but referred to by former name in the questionnaire

***recently relaunched as Foundation Modern Apprenticeships but referred to by former name in the questionnaire

12.8.2 Awareness of training initiatives generally increases with increasing size of employer. NVQs/SVQs are almost universally known across all sizes of employer. There is no consistent pattern by size of employer over time in the proportion aware of training initiatives.

12.8.3 Awareness of training initiatives does not vary consistently over time by industry sector or region, although the level of awareness of NVQs/SVQs has always been high in all sectors and regions. 
12.8.4 The proportion of employers stating that they had been involved with these initiatives over the previous 12 months is shown in the table below. (It should be noted that although the question was only asked of employers who were aware of an initiative, results have been repercentaged and those reported relate to all employers). It is not possible to provide comparable data over time for New Deal.

It should be noted when comparing figures that for NVQs/SVQs, Modern Apprenticeships and National Traineeships, the wording used was slightly different in 2000 to in earlier years. In the $1997-1999$ studies we asked "which of these initiatives, to your knowledge, has your company been involved with at some time in the last 12 months?" In the 2000 study we asked "have any of your employees been on any of the following initiatives in the last 12 months?" So results may not be strictly comparable.

Table 128 Involvement with training initiatives

\begin{tabular}{lcccc}
\hline & 1997 & $\mathbf{1 9 9 8}$ & $\mathbf{1 9 9 9}$ & $\mathbf{2 0 0 0}$ \\
& $\%$ & $\%$ & $\%$ & $\%$ \\
\hline NVQs/SVQs & 52 & 50 & 58 & 48 \\
Modern Apprenticeships* & 15 & 15 & 18 & 17 \\
National Record of Achievement & 10 & 8 & 12 & 10 \\
National Traineeships** & $\mathrm{n} / \mathrm{a}$ & 2 & 7 & 3 \\
\hline
\end{tabular}

Base: all employers

Coverage: all employers aware of each initiative

*recently relaunched as Advanced Modern Apprenticeships but referred to by former name in the questionnaire

**recently relaunched as Foundation Modern Apprenticeships but referred to by former name in the questionnaire

12.8.5 There is no consistent pattern over time by size, industry sector or region of employer in the proportion who had been involved with the various training initiatives.

12.8.6 The proportion of employers aware of NVQs/SVQs who were offering the qualification to employees at the location at the time of interview was $41 \%$ in the 1997 study, $47 \%$ in the 1999 study and 43\% in the most recent study (equivalent data are not available for the 1998 study).

Whilst $47 \%$ of employers reported that some employees had been involved with NVQs/SVQs over the past 12 months, only $43 \%$ reported that they were currently offering the qualification, indicating that it is likely that some employers had stopped offering NVQs/SVQs.

12.8.7 There have been no consistent changes over time by size, industry sector or region of employer in the proportion offering NVQs/SVQs.

12.8.8 Satisfaction levels with NVQs/SVQs have been over $80 \%$ in all four studies. 
Chapter 13

\section{Technical Appendix}




\section{Technical Appendix}

\subsection{Sampling Approach}

13.1.1 The sample was drawn from BT's Business Database, a regularly updated list of establishments with a business telephone line. The database gives complete coverage of all establishments with a business telephone line with the exception of those with whom BT is in sensitive commercial negotiations at the time (a very few large establishments), those in the Kingston-upon-Hull area who are served by Kingston Communications and very new start-up businesses.

13.1.2 Sample design involved quota sampling with stratification by 9 Government Office regions, 5 industry sectors (defined by 1992 SIC) and 6 sizes of establishment defined by the number of employees at the location, using variable sampling fractions. Sampling targets were set by:

- Distributing half the sample equally across the nine Government Office regions and the other half in proportion to the number of establishments in each region (this ensures sufficient interviews in smaller regions)

- Distributing interviews equally by industry sector (this ensures sufficient interviews in smaller industry sectors)

- Allotting 1500 interviews to establishments having 1-24 employees and 2500 to those having 25 or more, and then within each of these subgroups, sampling with probability proportional to size (this ensures sufficient interviews with smaller employers whilst also yielding the required oversampling of larger employers which is necessary due to the disproportionate share of employment they represent).

\subsection{The Questionnaire}

13.2.1 The questionnaire followed that used in the 1999 Learning and Training at Work as closely as possible in order to allow comparative analysis. To ensure that the interview, including the time taken to collect datasheet information, was no longer than 20 minutes, it was necessary to delete a number of questions, mainly relating to NVQs and New Deal. Some minor improvements were also made to the way in which questions dealing with employer 'involvement' with a number of the government initiatives covered were asked.

13.2.2 Questions on the main questionnaire and the datasheet were found to work satisfactorily.

\subsection{Piloting and Method of Data Collection}

13.3.1 The questionnaire was piloted during May 2000. Two hundred interviews were conducted with employers from a broad range of industry sectors, sizes of establishment and Government Office regions. Particular attention was paid to the information on the datasheet as this was a new aspect to the study.

13.3.2 As a result of the pilot very minor changes were made to the questionnaire and some questions on the datasheet were simplified in order to make them less daunting to employers.

13.3.3 Data collection for the main questionnaire was carried out using Computer Assisted Telephone Interviewing (CATI). 
13.3.4 Information relating to the costs of training was collected through a two stage process:

- Mailing a datasheet to those employers who stated during the telephone interview that they had provided training over the previous 12 months and asking them to complete it (if necessary, through reference to written records and/or colleagues)

- Recalling to collect the information on the telephone using CATI.

\subsection{The Respondent}

13.4.1 Interviews in establishment with 25 or more employees were conducted with the "personnel or training director or manager / the director or senior manager who is responsible for training at this location".

Interviews with smaller establishments were carried out with the owner or Managing Director.

13.4.2 With very few exceptions, all questions related strictly to the establishment where the employer was based. The information given by respondents did not therefore reflect the position of their company as a whole, unless that company was a single site operation.

\subsection{Interviews Obtained and Response Rates}

13.5.1 A total of 4001 interviews were obtained. Datasheets were received from 924 of the 3668 employers who had provided training over the previous 12 months, of which those from 883 were of sufficient quality to be useable in analysis.

13.5.2 The distribution by size of establishment of the main interviews and of useable datasheets was as follows:

Table 129 Distribution of achieved interviews and useable datasheets by size of employer

\begin{tabular}{lcc}
\hline & Interviews & Datasheets \\
\hline $1-4$ & 503 & 61 \\
$5-24$ & 1065 & 256 \\
$25-99$ & 963 & 234 \\
$100-199$ & 449 & 118 \\
$200-499$ & 515 & 119 \\
$500+$ & 506 & 95 \\
& & \\
TOTAL & 4001 & 883 \\
\hline
\end{tabular}


13.5.3 The distribution by industry sector of the main interviews and of useable datasheets was as follows:

Table 130 Distribution of achieved interviews and useable datasheets by industry sector of employer

\begin{tabular}{lcc}
\hline & Interviews & Datasheets \\
\hline Manufacturing (SIC Section D) & 833 & 202 \\
$\begin{array}{l}\text { Agriculture, mining, utilities, construction } \\
\quad \text { (SIC Sections A, B, C, E, F) }\end{array}$ & 610 & 122 \\
$\begin{array}{l}\text { Distribution \& consumer services } \\
\quad \text { (SIC Sections G, H) }\end{array}$ & 714 & 123 \\
$\begin{array}{l}\text { Finance \& business services } \\
\quad \text { (SIC Sections J, K) }\end{array}$ & 909 & 207 \\
$\begin{array}{l}\text { Transport, public administration \& other } \\
\quad \text { services (SIC Sections I, L, M, N, O) }\end{array}$ & 935 & 229 \\
$\quad$ TOTAL & 4001 & 883 \\
\hline
\end{tabular}

13.5.4 The distribution by Government Office region of the main interviews and of useable datasheets was as follows:

Table 131 Distribution of achieved interviews and useable datasheets by Government Office region of employer

\begin{tabular}{lcc}
\hline & Interviews & Datasheets \\
\hline North East & 311 & 67 \\
North West & 450 & 106 \\
Yorkshire and the Humber & 387 & 103 \\
East Midlands & 381 & 85 \\
West Midlands & 401 & 98 \\
Eastern & 457 & 102 \\
London & 603 & 112 \\
South East & 562 & 109 \\
South West & 449 & 101 \\
TOTAL & & \\
\hline
\end{tabular}


13.5.5 The overall response rate for the non-costs element of the survey was $66 \%$, comparable with that obtained in previous years.

The useable response rate for the costs element of the study was $24 \%$, lower than hoped for but perhaps not surprising given the complexity of information that we were trying to collect and the effort required on behalf of the employer to provide it.

13.5.6 There was little difference between different types of employer in the former figure: very small and very large employers were less likely to provide a useable datasheet.

Table 132 Response rate to datasheet by size of employer

\begin{tabular}{lc}
\hline & $\begin{array}{c}\text { Response } \\
\text { rate }\end{array}$ \\
\hline $1-4$ & $18 \%$ \\
$5-24$ & $27 \%$ \\
$25-99$ & $25 \%$ \\
$100-199$ & $27 \%$ \\
$200-499$ & $23 \%$ \\
$500+$ & $19 \%$ \\
TOTAL & \\
\hline
\end{tabular}

\subsection{Data Simulation}

13.6.1 It is not possible to calculate the costs of training without each dataset record having a response to each question. Not surprisingly, not all employers were able to answer every question.

13.6.2 From an inspection of the data provided, item non-response was simulated as described in paragraph 13.6.4. The rationale behind the procedure adopted was:

1) For questions not dealing with salary information, size of establishment is the variable with which the information is most correlated. When possible data was simulated within each of the size bands used for sample stratification : in a few cases where the data was counter intuitive size bands were combined.

2) For questions dealing with salary, London as against the Rest of England was the most important variable. An attempt was also made to allow for whether an establishment was an above average, an average, or a below average 'payer', by examining responses to other salary related questions that were answered by that employer. Salary questions were examined in a hierarchical order so that questions referring to employees of the most similar nature to that to which the question whose response was being simulated were examined.

13.6.3 It was not practical to simulate using a greater number of cells as the base sizes used for simulation would have been too small. 
13.6.4 The precise simulation procedure employed for each question is shown below. The proportion of records for which the response to each question needed to be simulated is also shown. Reference should be made to the datasheet at the back of this report.

\begin{tabular}{|c|c|c|}
\hline Question & Procedure & $\%$ simulated \\
\hline D1 & Simulated within 6 employee size bands & 4 \\
\hline D2 & Simulated within 6 employee size bands & 19 \\
\hline \multirow[t]{6}{*}{ D3 } & Within London / rest of England aggregated & 17 \\
\hline & $\begin{array}{l}\text { 1) See if QD17 answered and, if so, examine what } \\
\text { percentage above/below the average for QD17 } \\
\text { response is for this record and uplift/reduce QD3 } \\
\text { average by this percentage to generate QD3 value for } \\
\text { the record }\end{array}$ & \\
\hline & 2) If QD17 not answered, apply procedure at 1) to QD21 & \\
\hline & 3) If QD21 not answered, apply procedure at 1) to QD24 & \\
\hline & 4) If QD24 not answered, apply procedure at 1) to QD10 & \\
\hline & 5) If QD10 not answered, use average value at QD3 & \\
\hline
\end{tabular}

ie if a record in London was blank at QD3 and QD17 for this record was $£ 25,000$ against a London average at QD17 of $£ 22,723$. D3 London average was $£ 20,204$, so simulated QD3 for this record would be $£ 20,204 \times\{1+(£ 25,000-£ 22,723 / £ 22,723)\}=£ 22,229$

D4 Simulated within 6 employee size bands 19

D5 N/a 0

D6a $\quad$ Simulated within 6 employee size bands (not treated as a 8 salary question as picks up total not average salary information)

D6b Simulated within 5 employee size bands, combining 100199 and 200-499 bands, as averages for these individually looked odd

D7 Simulated within 6 employee size bands

D8 Simulated within 6 employee size bands 2

D9 $\quad$ Simulated within 6 employee size bands 6

D10 Similar procedure as for QD3, but order in which other 17 salary questions used was D24, D3, D17, D21

D11 Simulated within 5 employee size bands, combining 25-99 26 and 100-199 bands as averages for these individually looked odd

D12 Simulated within 6 employee size bands 23

D13 Simulated within 6 employee size bands 18

D14 Simulated within 6 employee size bands 13

D15 Simulated within 6 employee size bands 8

D16 Simulated within 6 employee size bands 19

D17 Similar procedure to QD3, but order in which other salary 17 questions used was D3, D21, D24, D10 


\begin{tabular}{|c|c|c|}
\hline Question & Procedure & $\%$ simulated \\
\hline D18 & $\begin{array}{l}\text { Simulated within } 5 \text { employee size bands, combining } 100- \\
199 \text { and } 200-499 \text { bands as averages for these individually } \\
\text { looked odd }\end{array}$ & 22 \\
\hline D19 & Simulated within 6 employee size bands & 13 \\
\hline D20 & Simulated within 6 employee size bands & 8 \\
\hline D21 & $\begin{array}{l}\text { Similar procedure to QD3, but order in which other salary } \\
\text { questions used was D24, D10, D3, D17 }\end{array}$ & 24 \\
\hline D22 & Simulated within 6 employee size bands & 12 \\
\hline $\mathrm{D} 23$ & Simulated within 6 employee size bands & 11 \\
\hline D24 & $\begin{array}{l}\text { Similar procedure to QD3, but order in which other salary } \\
\text { questions used was D10, D3, D17, D21 }\end{array}$ & 24 \\
\hline
\end{tabular}




\subsection{Calculation of Costs of Training}

13.7.1 The costs of providing training were calculated through use of each of the individual questions on the datasheet. The formula used is set out in paragraph 13.7.3.

13.7.2 A few points should be borne in mind:

- The pilot showed that employers were able to give salary costs but not total labour costs. It was therefore necessary to uplift the salary costs given to generate total labour costs. Figures were obtained from the 2000 New Earnings Survey (NES) which indicated that basic salaries, on average, need to be uplifted by $9.9 \%$ to allow for bonus, overtime and Performance Related Pay (PRP) payments. Allowing for employers' National Insurance contributions at $12.2 \%$ (and the fact that this is not payable on the first $£ 84$ of weekly earnings) led to salary costs being uplifted by $20.6 \%$ to generate labour costs

- Labour Force Survey (LFS) data for September to November 2000 (the period when most datasheets were completed) indicates that, on average, employees work for 207 days a year and for 7.2 hours a day. These figures were used when converting data given by employers for various periods to annual estimates

- When converting data relating to on-the-job training which related to a typical month' to annual estimates, it was assumed that trainees were available for on-thejob training for 11 months a year

- The datasheet collected the total salaries of all full time and part time training staff (Q6a) but did not ask what proportion of training centre staff worked full and part time. In order not to lead to an overestimate, LFS and NES data on the proportion of staff working full and part time and their average salaries were used to calculate the factors by which the total salary figures by employers should be downweighted. The figure used was 0.83 .

13.7.3 The formula used to calculate the costs of training was as follows:

\section{Off-the-job training}

\section{Training courses}

$\begin{array}{lll}\text { a) } & \text { - trainee labour costs } & \mathrm{Q} 1 \times \mathrm{Q} 2 \times 1.206 \frac{\mathrm{Q} 3}{207} \\ \text { b) } & \text { - fees to external providers } & \mathrm{Q} 4 \\ \text { c) } & \text { - on-site training centre } & (1.206 \times 0.83 \times \mathrm{Q} 6 \mathrm{a})+\mathrm{Q} 6 \mathrm{~b} \\ \text { d) } & \begin{array}{l}\text { - off-site training centre } \\ \text { belonging to same company }\end{array} & \mathrm{Q} 7 \\ \text { e) } & \text { - training management } & \mathrm{Q} 8 \times \frac{\mathrm{Q} 9 \times 1.206 \mathrm{Q} 10}{100} \\ \text { f) } & \text { - non-training centre equipment } & \mathrm{Q} 11 \\ \text { g) } & \quad \text { and materials } & \\ \text { h) } & \text { travel and subsistence } & \mathrm{Q} 12 \\ \end{array}$

\section{Other}

i) - trainee labour costs

Q15 x Q16 x $\frac{1.206}{207} \mathrm{Q} 17$

j) - fees to external providers

Q18 


\section{On-the-job training}
k) Trainees' labour costs
$\mathrm{Q} 19 \times \mathrm{Q} 20 \times \frac{1.206 \mathrm{Q} 21}{207 \times 7.2} \times 11$
I) Trainers' labour costs
$\mathrm{Q} 22 \times \mathrm{Q} 23 \times \frac{1.206 \mathrm{Q} 24 \times 11}{207 \times 7.2}$

The total cost of off-the-job training is the sum of elements a) $-j$ ), and that of on-the-job training the sum of elements $\mathrm{k}$ ) and I). The total cost of all training is the sum of elements a) - l).

\subsection{Grossing-up}

13.8.1 Data for the non-costs related element of the study were grossed up to 1998 Annual Employment Survey (AES) data on the $5 \times 6 \times 9$ industry sector $\times$ establishment size $\times$ government office region matrix, used for sample stratification.

13.8.2 The procedure used to gross up information relating to the costs of training was as follows:

1) Calculate the costs of each establishment completing a datasheet providing a) off-thejob training and $b$ ) on-the-job training using the formula cited earlier

2) Gross up the costs of providing off-the-job training to the population of establishments providing off-the-job training as identified from analysis of the dataset responding to the main questionnaire

3) Gross up the costs of providing on-the-job training to the population of establishments providing on-the-job training, as identified from analysis of the dataset responding to the main questionnaire

4) Add 2) and 3) together.

13.8.3 It was not possible to use the $5 \times 6 \times 9$ matrix for grossing up costs data as individual cell sizes would have been too small. The data was therefore rim weighted by the three variables. 


\section{Appendices}

Screening Questionnaire

Main Questionnaire

Datasheet 


Office Use only:
\begin{tabular}{|c|l|l|l|l||}
\hline SERIAL & & & \\
\hline & & & & \\
\hline$(101)$ & & & $(104)$ & $(105)$ \\
\hline
\end{tabular}

Address Label or Written Details

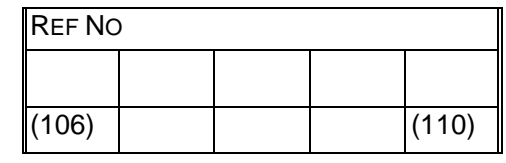

\begin{tabular}{|l|l|l||}
\hline REGION & \multicolumn{2}{|l||}{ Country } \\
\hline & & \\
\hline$(111)$ & $(112)$ & $(113)$ \\
\hline
\end{tabular}

\begin{tabular}{|c|c|}
\hline FINAL OUTCOME (CODE ONE ONLY) & $(114-115)$ \\
\hline Respondent interviewed ...................... & 01 \\
\hline Breakdown during interview.................. & 02 \\
\hline Out of quota (S16/17 or 18) ................. & 03 \\
\hline Non qualifier (No employees at S16/17) & 04 \\
\hline Refusal: (SPECIFY)... & 10 \\
\hline Not available in deadline...................... & 11 \\
\hline Referred to other address / telephone numbe & Jer 12 \\
\hline No contact with resp after 5 tries .......... & 13 \\
\hline Unobtainable / dead line / fax number.. & 14 \\
\hline 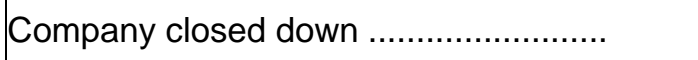 & 15 \\
\hline Respondent moved / no longer at address & 16 \\
\hline Wrong number ............ & 17 \\
\hline Other (DESCRIBE). & 00 \\
\hline
\end{tabular}

\section{Contact Record - Please complete for every contact, however short}

\begin{tabular}{|l|l|l|l|l|}
\hline No & Date & Time & Spoke to & Outcomes \\
\hline 1 & & & & \\
\hline 2 & & & & \\
\hline 3 & & & & \\
\hline 4 & & & & \\
\hline 5 & & & & \\
\hline 6 & & & & \\
\hline 7 & & & & \\
\hline
\end{tabular}

Please use:

$\mathrm{NDC}=$ No Direct Contact $\quad \mathrm{DC}=$ Direct Contact $\quad \mathrm{NR}=$ No Reply $\quad \mathrm{C} / \mathrm{B}=$ Call Back $\quad$ Eng $=$ Engaged 
ASK TELEPHONIST

S1) Can I just check, is that (COMPANY) of (ADDRESS)?

\begin{tabular}{|l|l|l|}
\multicolumn{1}{c}{(} & $($ ) \\
\hline Yes & 1 & GO TO S3 \\
\hline No & 2 & ASK S2 \\
\hline
\end{tabular}

IF COMPANY NAME I ADDRESS DIFFERENT

S2) What is the correct company name? WRITE IN COMPANY NAME ADDRESS

S3) Can I just check that your postcode is (POSTCODE)?

\begin{tabular}{|l|l|l|}
\multicolumn{1}{c}{(} & ( \\
\hline Yes & 1 & GO TO S5 \\
\hline No & 2 & ASK S4 \\
\hline
\end{tabular}

\section{IF WRONG}

S4) What is the correct postcode? WRITE IN

S5) May I please speak to....

SMALL ESTABLISHMENTS (1-24 EMPLOYEES) ....the Owner or Managing Director?

OR

LARGER ESTABLISHMENTS (25 OR MORE EMPLOYEES) ....the Personnel or Training Director or Manager / the Director or Senior Manager here who is responsible for training at this establishment?

\begin{tabular}{|l|l|l|}
\multicolumn{1}{l|}{$(\boldsymbol{l})$} \\
\hline Put through & 1 & GO TO S9 \\
\hline Person based elsewhere & 2 & ASK S6 \\
\hline No such person & 3 & GO TO S7 \\
\hline Refused to put through & 4 & CLOSE (OUTCOME 10) \\
\hline Call back later & 5 & MAKE APPOINTMENT \\
\hline
\end{tabular}

\section{ASK S6 IF PERSON BASED ELSEWHERE AT S5}

S6) Can you give me the details of the person I need to speak to?

RECORD DETAILS : WRITE IN NAME, JOB TITLE, COMPANY NAME, ADDRESS, PHONE NUMBER THEN CLOSE (OUTCOME 12)

\begin{tabular}{|l|l|}
\hline & \\
\hline & \\
\hline & CLOSE \\
\hline & (OUTCOME 12) \\
\hline
\end{tabular}


ASK S7 IF NO SUCH PERSON AT S5

S7) May I speak to the most senior person at this site please? Can I check his/ her name? WRITE IN NAME

S8) Can I check his/her job title?

\begin{tabular}{|l|l|l|}
\hline Owner / Chairman / MD / Partner & \multicolumn{1}{c|}{ ) } \\
\hline $\begin{array}{l}\text { Director / Manager of Personnel / Human Resources / } \\
\text { Recruitment / Employee Relations }\end{array}$ & 1 & \\
\hline Training Director / Manager & 2 & \\
\hline General / Site / Factory / Works Director / Manager & 4 & \\
\hline Administration / Office Director / Manager & 5 & \\
\hline $\begin{array}{l}\text { Finance Director / Manager / Accountant / Company } \\
\text { Secretary }\end{array}$ & 6 & \\
\hline Other Departmental Director / Manager & 7 & \\
\hline Senior Secretary / Secretary & 8 & \\
\hline Other (WRITE IN)......................................................... & 0 & \\
\hline
\end{tabular}

\section{ASK ALL}

S9) My name is ___ of IFF Research Ltd. We are conducting a major study for the Department for Education and Employment about the training practices of employers REASSURANCES : READ OUT TO EVERY RESPONDENT

The results of the survey will be used to help develop policies at both a national and regional level.

Participation is entirely voluntary and no responses will be attributed to any individual or company. Results will be reported to the Department for Education and Employment on an aggregated basis only. The interview will take no more than 20 minutes. We may also want to fax you a short written questionnaire, concerned with cost of providing training at this establishment.

\section{IF NECESSARY, ADD:}

- Even if you do not carry out any training, we are still interested in talking to you

- If you require further information or wish to check the validity of this study, please contact either Jon Sanwell at IFF on 0207837 6363, or Bulwinder Singh at the DfEE on 01142594350

- A summary of the results of this survey will be posted on the DfEE website (www.dfee.gov.uk) on completion of the project.

- The results from the equivalent 1999 survey have been posted at http://www.dfee.gov.uk/research/briefs/Brief202.doc

S10) Can I just check that you are the best person for me to talk to about the training you undertake at this establishment?

\begin{tabular}{|c|c|c|}
\hline & & \\
\hline Respondent OK and willing to be interviewed & 1 & Go TO S16 \\
\hline Respondent OK but call back later & 2 & MAKE APPOINTMENT \\
\hline Respondent OK but refuses to be interviewed & 3 & CLOSE (OUTCOME 10) \\
\hline Someone else at establishment & 4 & \\
\hline NAME & & $\begin{array}{l}\text { TRANSFER AND } \\
\text { REINTRODUCE }\end{array}$ \\
\hline JOB TITLE. & & \\
\hline $\begin{array}{l}\text { Matters only dealt with at a higher level / central } \\
\text { establishment of organisation }\end{array}$ & 5 & ASK S11 \\
\hline
\end{tabular}


ASK S11 IF DEALT WITH AT HIGHER LEVEL OF ORGANISATION

S11) Does this mean that no-one here has a say in the types and amount of training undertaken at this establishment?

\begin{tabular}{|l|l|l|}
\hline No-one here has a say & 1 & ASK S12 \\
\hline Someone else has a say & 3 & \\
\hline AME & & TRANSFER AND \\
\hline OB TITLE & & \\
\hline Don't know & 3 & CLOSE (OUTCOME 12) \\
\hline
\end{tabular}

IF NO-ONE RESPONSIBLE OR RESPONDENT NOT ALLOWED TO GIVE INTERVIEW, COLLECT DETAILS OF PERSON AT HIGHER LEVEL OF ORGANISATION AND THEIR RESPONSIBILITIES BUT DO NOT CONTACT AT THIS STAGE

S12) NAME OF BEST PERSON TO CONTACT

S13) LOCATION OF BEST PERSON TO CONTACT

S14 JOB TITLE

\begin{tabular}{|c|c|c|}
\hline & \multicolumn{2}{|c|}{ ) } \\
\hline Owner / Chairman / MD / Partner & 1 & \\
\hline $\begin{array}{l}\text { Director / Manager of Personnel / Human Resources / } \\
\text { Recruitment / Employee Relations }\end{array}$ & 2 & \\
\hline Training Director / Manager & 3 & \\
\hline General / Site / Factory / Works Director / Manager & 4 & \\
\hline Administration / Office Director / Manager & 5 & \\
\hline $\begin{array}{l}\text { Finance Director / Manager / Accountant / Company } \\
\text { Secretary }\end{array}$ & 6 & \\
\hline Other Departmental Director / Manager & 7 & \\
\hline Senior Secretary / Secretary & 8 & \\
\hline Other (WRITE IN) & 0 & \\
\hline
\end{tabular}

S15) PHONE NUMBER

NOW CLOSE (OUTCOME 12) 
ASK ALL QUALIFYING SO FAR

S16) Firstly, can I check how many employees - full and part time - you have at your (STREET)

location?

ENTER ABSOLUTE NUMBER

\begin{tabular}{|l|c|l|l|}
\hline None & 1 & CLOSE (OUTCOME 04) \\
\hline $1-999999999$ & & GO TO S18 \\
\hline Don't know / refused & X & ASK S17 \\
\hline
\end{tabular}

\section{IF DON'T KNOW I REFUSED AT S16}

S17) Can you tell me which of these bands best represents the number of employees you have at this location?

READ OUT

\begin{tabular}{|c|c|c|}
\hline & & ) \\
\hline None & 1 & CLOSE (OUTCOME 04) \\
\hline $1-4$ & 2 & \multirow{9}{*}{ ASK S18 } \\
\hline $5-9$ & 3 & \\
\hline $10-24$ & 4 & \\
\hline $25-49$ & 5 & \\
\hline $50-99$ & 6 & \\
\hline $100-199$ & 7 & \\
\hline $200-499$ & 8 & \\
\hline $500-999$ & 9 & \\
\hline 1,000 or more & 0 & \\
\hline Don't know / refused & $x$ & CLOSE (OUTCOME 00) \\
\hline
\end{tabular}

ASK ALL WITH ONE OR MORE EMPLOYEE AT S16/17

18) What is the main business activity at this location? Precisely what is made, sold or provided here? WRITE IN AND CODE BELOW. PROBE FOR FULL DETAILS. DO NOT ACCEPT ANSWERS SUCH AS "ENGINEERING"

\begin{tabular}{|l|}
\hline \\
\hline \\
\hline \\
\hline
\end{tabular}

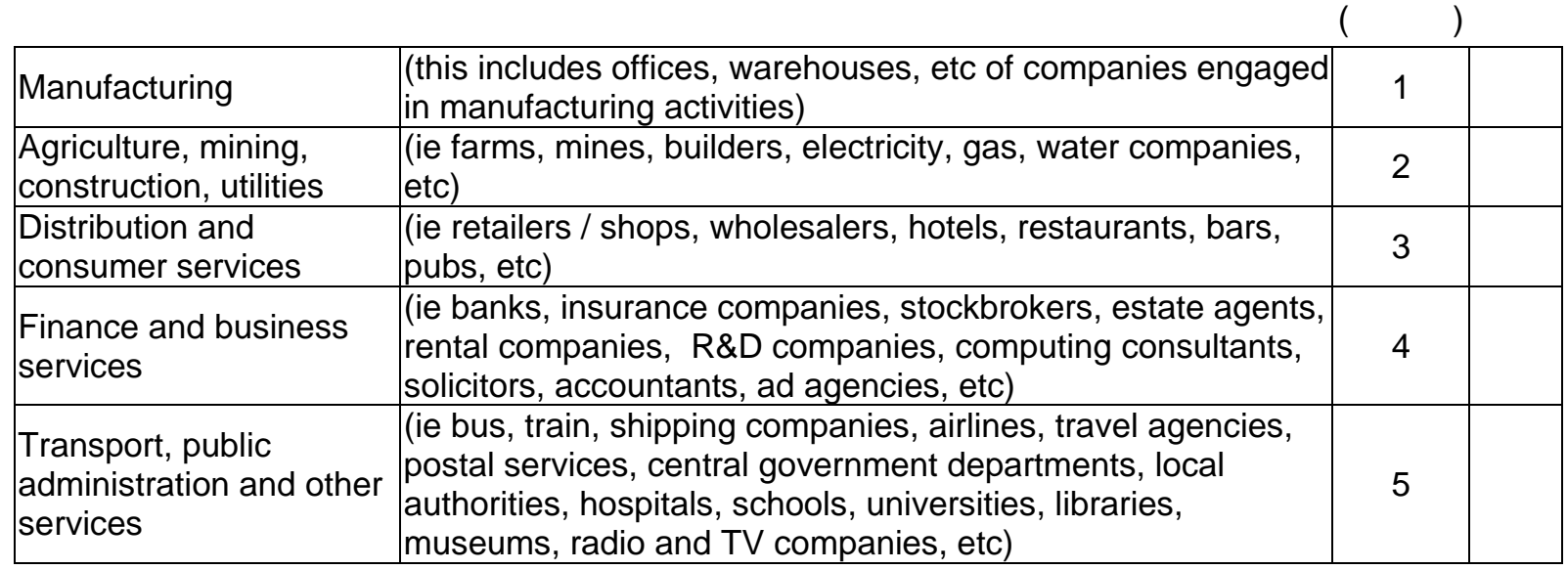

NOW GO TO MAIN QUESTIONNAIRE IF IN QUOTA (IF NOT, CLOSE OUTCOME 03) 
MAINSTAGE

Telephone Questionnaire

\begin{tabular}{|l|l|}
\hline Start Time: & \\
\hline Company Name: & \\
\hline Respondent: & \\
\hline Job Title: & \\
\hline Interviewer: & \\
\hline
\end{tabular}

1) Firstly, do you currently have any vacancies at this location that are proving hard-to-fill?

\begin{tabular}{|l|l|l|}
\multicolumn{1}{c}{$\left({ }^{2}\right)$} \\
\hline Yes & 1 & \\
\hline No & 2 & \\
\hline
\end{tabular}

2) Which of these age groups do you currently employ at this location? READ OUT AND CODE ALL MENTIONED

\begin{tabular}{|c|c|c|}
\hline 16 - 17 year olds & 1 & \multirow{3}{*}{ ASK Q3 } \\
\hline 18 - 19 year olds & 2 & \\
\hline 20 - 24 year olds & 3 & \\
\hline None of the above & 9 & \multirow{2}{*}{ Go TO Q7 } \\
\hline Don't know & $x$ & \\
\hline
\end{tabular}



have already attained a Level 2 qualification or equivalent? By "level or 2 or equivalent" I mean qualifications such as 5 GCSEs at grade A-C, BTEC first or general diploma, GNVQ intermediate or NVQ Level 2 itself

WRITE IN GRID. PROMPT WITH RANGES AS NECESSARY (none, 1-9\%, 10-24\%, 25$49 \%, 50-74 \%, 75-99 \%$, all)

4) And what percentage of your 2 qualification or equivalent? (AGE FROM Q2) year olds are working towards a Level WRITE IN GRID. PROMPT WITH RANGES AT Q3 AS NECESSARY

5) What percentage of the __ (AGE FROM Q2) year olds that you employ at this location have already attained a Level $\mathbf{3}$ qualification or equivalent? By "level 3 or equivalent" I mean qualifications such as 2 A levels, BTEC National, GNVQ advanced or NVQ Level 3 itself. WRITE IN GRID. PROMPT WITH RANGES AT Q3 AS NECESSARY

6) And what percentage of your 3 qualification or equivalent? (AGE FROM Q2) year olds are working towards a Level WRITE IN GRID. PROMPT WITH RANGES AT Q3 AS NECESSARY

\begin{tabular}{|l|r|c||r|r|}
\hline & \multicolumn{2}{|c||}{ NVQ Level 2 } & \multicolumn{2}{c|}{ NVQ Level 3 } \\
\hline Age & $\begin{array}{c}\text { Q3 } \\
\text { Attained }\end{array}$ & $\begin{array}{c}\text { Q4 } \\
\text { Working } \\
\text { towards }\end{array}$ & $\begin{array}{c}\text { Q5 } \\
\text { Attained }\end{array}$ & $\begin{array}{c}\text { Q6 } \\
\text { Working } \\
\text { towards }\end{array}$ \\
\hline $16-17$ & $\%$ & $\%$ & $\%$ & $\%$ \\
\hline $18-19$ & $\%$ & $\%$ & $\%$ & $\%$ \\
\hline $20-24$ & $\%$ & $\%$ & $\%$ & $\%$ \\
\hline
\end{tabular}

7) Turning now to the overall skills needed at your location to keep it running effectively, would you say that the need for skills in your average employee was...?

READ OUT

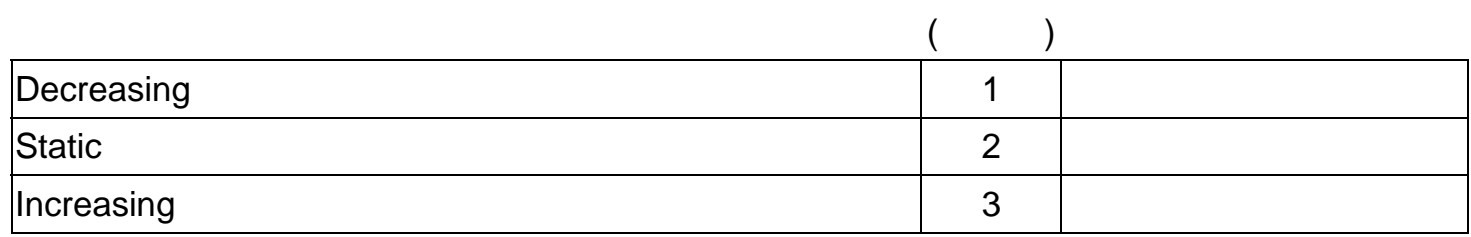

8) Broadly speaking, what proportion of your existing staff at this location would you regard as being fully proficient at their current job?

READ OUT. CODE ONE ONLY

\begin{tabular}{|c|c|c|}
\hline & & \\
\hline All & 1 & \\
\hline Nearly all & 2 & \\
\hline Over half & 3 & \\
\hline Some but under half & 4 & \\
\hline Very few & 5 & \\
\hline
\end{tabular}


9) Which of the following exist at your establishment?

READ OUT. CODE ALL MENTIONED

\begin{tabular}{|l|l|l|}
\hline A business plan & 1 & \\
\cline { 1 - 2 } $\begin{array}{l}\text { A human resources plan that forecasts the numbers and } \\
\text { types of staff that will be needed in the year ahead }\end{array}$ & 2 & \multirow{2}{*}{ ASK Q10 } \\
\cline { 1 - 2 } $\begin{array}{l}\text { A training plan that specifies in advance the level and type } \\
\text { of training your employees will need in the coming year }\end{array}$ & 3 & \\
\cline { 1 - 2 } A budget for training expenditure & 4 & \\
\cline { 1 - 2 } None of these & 9 & GO TO Q11 \\
\hline
\end{tabular}

ASK FOR EACH TYPE THAT EXISTS AT Q9 (IF NONE EXIST GO TO Q11) 10) Is __ a formal written plan, or does it exist in practice but less formally?

Business resource Training plan

plan

plan

Budget for

training

expenditure

\begin{tabular}{|c|c|c|c|c|c|}
\hline & plan & plan & & blan & expenditure \\
\hline & ( & ) ( & ) ( & & ) \\
\hline Formal, written & 1 & 1 & & 1 & 1 \\
\hline Less formal & 2 & 2 & & 2 & 2 \\
\hline Don't know & $x$ & $x$ & & $x$ & $x$ \\
\hline
\end{tabular}

\section{ASK ALL}

11) Do you offer learning opportunities in any of the following to employees at this location? READ OUT AND CODE ALL MENTIONED

\begin{tabular}{|l|l|l|}
\hline Basic literacy & \multicolumn{1}{c|}{ ) } \\
\hline Basic numeracy & 1 & \\
\hline $\begin{array}{l}\text { Communication - through either written work or oral } \\
\text { presentation }\end{array}$ & 2 & \\
\hline Working with others & 3 & \\
\hline Application of numbers & 4 & \\
\hline Problem solving & 5 & \\
\hline Information technology & 6 & \\
\hline Managing their own development & 7 & \\
\hline None of the above & 8 & \\
\hline
\end{tabular}


ASK ALL

I am now going to ask you some questions about off-the-job training

12) By off-the-job training, we are including all training away from the immediate work position. It can be given at your premises or elsewhere. It includes all sorts of courses - full or part time; correspondence or distance learning; Health and Safety training, and so on - as long as it is funded or arranged by you.

Have you funded or arranged any off-the-job training over the past 12 months for any of the employees at this location?

\begin{tabular}{|l|c|l|}
\multicolumn{1}{c|}{(} & \\
\hline Yes & 1 & ASK Q13 \\
\hline No & 2 & \multirow{2}{*}{ GO TO Q25 } \\
\hline Don't know & $\mathrm{X}$ & \\
\hline
\end{tabular}

\section{IF YES}

13) Where does this off-the-job training take place?

READ OUT. CODE ALL MENTIONED

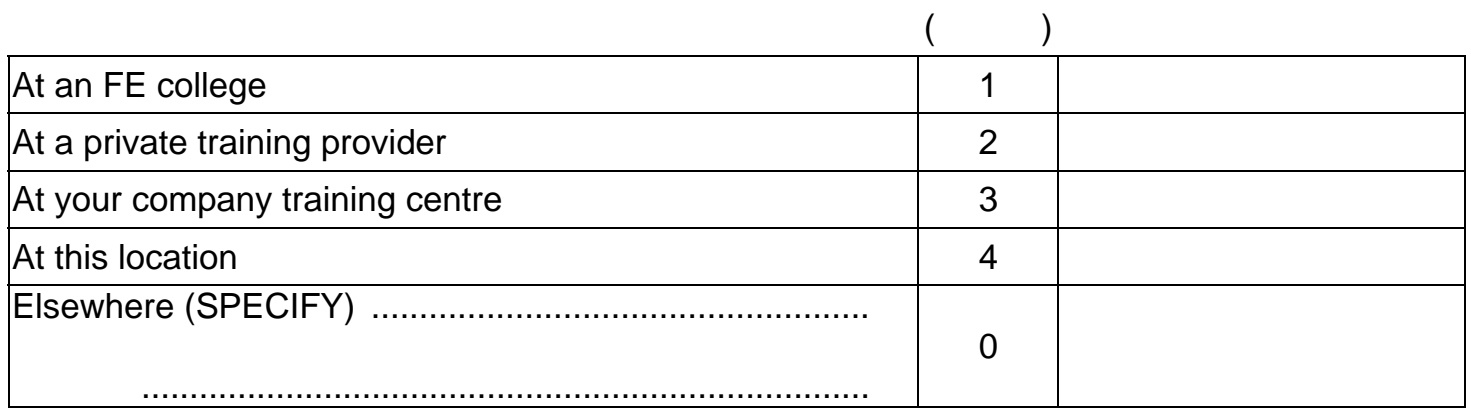

\section{ASK Q14 IF CODES 1 OR 2 AT Q13 (OTHERS GO TO Q15)}

14) How satisfied are you with the quality of the training provided by (AS APPROPRIATE) FE colleges and other outside providers?

READ OUT. CODE ONE ONLY

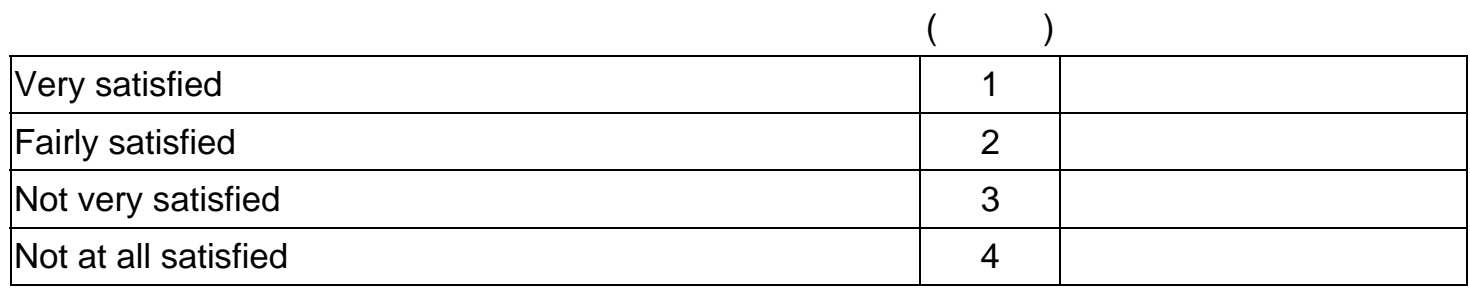




\section{ASK ALL PROVIDING OFF-THE-JOB TRAINING}

15) For how many of your employees have you funded or arranged off-the-job training over the past 12 months?

WRITE IN ABSOLUTE NUMBER

1 - 999999999

Don't know

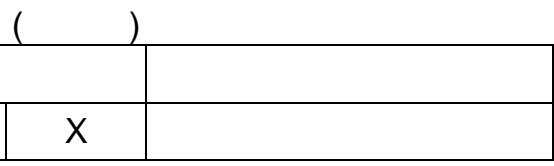

PROMPT WITH RANGES AS NECESSARY

\begin{tabular}{|l|l|l|}
\hline $1-2$ & 1 & \\
\hline $3-4$ & 2 & \\
\hline $5-9$ & 3 & \\
\hline $10-19$ & 4 & \\
\hline $20-29$ & 5 & \\
\hline $30-39$ & 6 & \\
\hline $40-49$ & 7 & \\
\hline $50-99$ & 8 & \\
\hline $100-199$ & $(1$ & \\
\hline 200 or more & 2 & \\
\hline
\end{tabular}

16) Over the past 12 months, about how many days off-the-job training have you funded or arranged for each person receiving such training?

WRITE IN ABSOLUTE NUMBER

\begin{tabular}{|l|l|l|l|}
\hline $1-365$ & \multicolumn{2}{|c|}{} & \\
\hline Don't know & $x$ & \\
\hline
\end{tabular}

PROMPT WITH RANGES AS NECESSARY

\begin{tabular}{|l|l|l|}
\hline 1 & $(1$ & \\
\hline 2 & 2 & \\
\hline $3-4$ & 3 & \\
\hline $5-6$ & 4 & \\
\hline $7-8$ & 5 & \\
\hline $9-10$ & 6 & \\
\hline $11-12$ & 7 & \\
\hline $13-14$ & 8 & \\
\hline $15-16$ & 9 & \\
\hline $17-18$ & $(2)$ & \\
\hline $19-20$ & 2 & \\
\hline More than 20 & 3 & \\
\hline
\end{tabular}


17) I am now going to ask you which of nine specific categories of staff - such as managers, clerical and secretarial staff, sales staff and skilled manual staff - you have at this location READ OUT EACH CATEGORY AND CODE ALL MENTIONED IN GRID BELOW. USE PROMPTS AS NECESSARY

\section{ASK FOR EACH CATEGORY CODED AT Q17}

18) And have you funded or arranged any off-the-job training over the past year for (OCCUPATION)?

$\overline{C O D E}$ ALL MENTIONED

\begin{tabular}{|c|c|c|c|c|}
\hline & & \multicolumn{2}{|c|}{$\begin{array}{cc}\text { Q17 } & \text { Q18 } \\
\text { Have } & \text { Trained }\end{array}$} & \\
\hline & & ( & )( & ) \\
\hline $\begin{array}{l}\text { Managers and senior } \\
\text { administrative occupations }\end{array}$ & $\begin{array}{l}\text { eg directors, branch managers, shopkeepers, } \\
\text { local government officers, publicans }\end{array}$ & 1 & 1 & \\
\hline Professional occupations & $\begin{array}{l}\text { eg accountants, civil engineers, R\&D scientists, } \\
\text { librarians, social workers, solicitors, teachers }\end{array}$ & 2 & 2 & \\
\hline $\begin{array}{l}\text { Technical and scientific } \\
\text { occupations }\end{array}$ & $\begin{array}{l}\text { eg computer programmers, lab technicians, } \\
\text { graphic designers, nurses }\end{array}$ & 3 & 3 & \\
\hline $\begin{array}{l}\text { Clerical and secretarial } \\
\text { occupations }\end{array}$ & $\begin{array}{l}\text { eg clerks, computer operators, secretaries, } \\
\text { bank clerks, telephone call centre staff }\end{array}$ & 4 & 4 & \\
\hline $\begin{array}{l}\text { Craft and skill operative } \\
\text { occupations }\end{array}$ & $\begin{array}{l}\text { eg builders, printers, machine setters, bakers, } \\
\text { electricians, chefs }\end{array}$ & 5 & 5 & \\
\hline $\begin{array}{l}\text { Personal service } \\
\text { occupations }\end{array}$ & eg waiters, bar staff, hairdressers & 6 & 6 & \\
\hline Sales occupations & eg sales assistants & 7 & 7 & \\
\hline $\begin{array}{l}\text { Operatives and assembly } \\
\text { occupations }\end{array}$ & $\begin{array}{l}\text { eg assembly workers, machine operators, bus } \\
\text { drivers }\end{array}$ & 8 & 8 & \\
\hline Other manual occupations & eg labourers, cleaners, shelf fillers & 9 & 9 & \\
\hline None of the above & & & $\mathrm{V}$ & \\
\hline
\end{tabular}

19) Which of the following methods of providing off-the-job training have you used over the past year?

\section{READ OUT. CODE "YES" OR "NO" FOR EACH}

\begin{tabular}{|l|l|l|l|l|}
\hline $\begin{array}{l}\text { Provided education and training courses that are intended to } \\
\text { lead to a qualification }\end{array}$ & $(\quad)$ & 1 & 2 & \\
\hline $\begin{array}{l}\text { Provided other taught courses designed to help employees } \\
\text { develop skills }\end{array}$ & $(\quad)$ & 1 & 2 & \\
\hline $\begin{array}{l}\text { Provided learning which involves employees studying on their } \\
\text { Own from a package of materials eg written materials, audio or } \\
\text { video tapes, TV programmes, computer software packages, CD } \\
\text { ROMs, the internet }\end{array}$ & $(\quad)$ & 1 & 2 & \\
\hline $\begin{array}{l}\text { Encouraged employees to keep up-to-date on the type of work } \\
\text { they do without taking part in a taught course, eg by reading } \\
\text { books, manuals, journals, or by attending seminars }\end{array}$ & $(\quad)$ & 1 & 2 & \\
\hline
\end{tabular}


20) Which of the following types of off-the-job training have you funded or arranged for employees at this location over the past year?

READ OUT. CODE ALL MENTIONED

\begin{tabular}{|l|l|l|}
\hline Induction training & 1 & \\
\hline Health and Safety training & 2 & \\
\hline Job specific training & 3 & \\
\hline Supervisory training & 4 & \\
\hline Management training & 5 & \\
\hline Training in new technology & 6 & \\
\hline Training in foreign languages & 7 & \\
\hline None of above & 9 & \\
\hline
\end{tabular}

21) Was any of the off-the-job training that you have funded or arranged over the last year for employees at this location leading to formal qualifications?

\begin{tabular}{|l|c|l|}
\multicolumn{1}{l|}{(} & \\
\hline Yes & 1 & ASK Q22 \\
\hline No & 2 & \multirow{2}{*}{ GO TO Q23 } \\
\hline Don't know & $\mathrm{X}$ & \\
\hline
\end{tabular}

\section{IF YES}

22) Which of the following qualifications are these?

READ OUT. CODE ALL MENTIONED

\begin{tabular}{|l|c|c|}
\hline NVQs & \multicolumn{1}{l|}{ ) } \\
\hline SVQs & 1 & \\
\hline $\begin{array}{l}\text { Other nationally recognised qualifications, eg RSA, BTEC, } \\
\text { City \& Guilds }\end{array}$ & 2 & \\
\hline Qualification specific to your company & 4 & \\
\hline Higher qualifications, such as degrees & 5 & \\
\hline Don't know & $\mathrm{X}$ & \\
\hline
\end{tabular}




\section{ASK ALL PROVIDING OFF-THE-JOB TRAINING}

23) Thinking of the organisation as a whole now, rather than just this location, does your organisation...?

READ OUT. CODE "YES" OR "NO" FOR EACH

\begin{tabular}{|l|l|l|l|l|l|}
\hline a) & $\begin{array}{l}\text { Have someone at senior management level responsible } \\
\text { for training }\end{array}$ & $(\quad)$ & 1 & 2 & \\
\hline b) & $\begin{array}{l}\text { Have a separate training facility, such as a training } \\
\text { school or centre, in your organisation }\end{array}$ & $(\quad)$ & 1 & 2 & \\
\hline c) & $\begin{array}{l}\text { Employ staff in your organisation to design and teach } \\
\text { training courses }\end{array}$ & $(\quad)$ & 1 & 2 & ASK Q24 \\
\hline
\end{tabular}

\section{ASK Q24 IF EMPLOY STAFF AT Q23c (OTHERS GO TO Q25)}

24) How many training staff do you employ in your organisation? WRITE IN ABSOLUTE NUMBER

\begin{tabular}{|l|l|l|l|}
\hline $1-99999$ & & \\
\hline Don't know & & $X$ & \\
\hline
\end{tabular}

PROMPT WITH RANGES AS NECESSARY

\begin{tabular}{|l|l|l|}
\hline $1-2$ & 1 & \\
\hline $3-4$ & 2 & \\
\hline $5-6$ & 3 & \\
\hline $7-8$ & 4 & \\
\hline $9-10$ & 5 & \\
\hline $11-12$ & 6 & \\
\hline $13-14$ & 7 & \\
\hline $15-16$ & 8 & \\
\hline $17-18$ & 9 & \\
\hline $19-20$ & $(1$ & \\
\hline More than 20 & 2 & \\
\hline
\end{tabular}


ASK ALL

Thinking again now just about this location, I am now going to ask you some questions about on-the-job training provided at this location

By on-the-job training, I mean training given at the desk or place where the person usually works. I'm not including off-the-job training which is given away from the usual work position

25) Have you carried out any on-the-job training at this location over the past 12 months?

\begin{tabular}{|l|c|l|}
\multicolumn{1}{l}{(} & \multicolumn{1}{l|}{ ( $)$} \\
\hline Yes & 1 & ASK Q26 \\
\hline No & 2 & \multirow{2}{*}{ GO TO FILTER ABOVE Q27 } \\
\hline Don't know & $\mathrm{X}$ & \\
\hline
\end{tabular}

\section{IF YES}

26) Which of the following methods have you used over the last year to provide on-the-job training to employees at this location?

READ OUT. CODE ALL MENTIONED

\begin{tabular}{|l|l|l|}
\hline $\begin{array}{l}\text { Training by your company training officer or specialist } \\
\text { training staff }\end{array}$ & 1 & \\
\hline Training by a line manager or supervisor & 2 & \\
\hline Training by other experienced staff at your company & 3 & \\
\hline $\begin{array}{l}\text { ONLY READ OUT IF NONE OF THE CODES 1, 2 } \\
\text { AND 3 ABOVE MENTIONED } \\
\text { Training by other staff in the company }\end{array}$ & 4 & \\
\hline CONTINUE WITH CODE 5 IN ALL CASES & & \\
\hline Training provided by equipment suppliers & 5 & \\
\hline Private sector training companies or consultancies & 6 & \\
\hline Computer based training packages & 7 & \\
\hline Other (WRITE IN) .......................................................... & 0 & \\
\hline
\end{tabular}

IF NO TRAINING PROVIDED AT ESTABLISHMENT (CODE 2 AT Q12 AND CODE 2 AT Q25)

(OTHERS GO TO Q28)

27) You mentioned earlier that training has not been provided for any employees at this location over the past twelve months. What are the main reasons for this?

PROBE: What other reasons? 
ASK ALL

28) Do you help your employees at this location to learn things not connected to their job?

\begin{tabular}{|l|l|l|}
\multicolumn{1}{c}{$(\boldsymbol{r})$} \\
\hline Yes & 1 & \\
\hline No & 2 & \\
\hline
\end{tabular}

29) a Do you have Staff Association or Trade Union representation at this location?

\begin{tabular}{|l|l|l|}
\multicolumn{1}{l}{(} & \multicolumn{2}{l|}{ ( $)$} \\
\hline Yes & 1 & ASK Q29b \\
\hline No & 2 & \multirow{2}{*}{ GO TO Q30 } \\
\hline Don't know & $X$ & \\
\hline
\end{tabular}

\section{IF "YES"}

Q29b Are these representatives involved in .....?

READ OUT AND CODE "YES" OR "NO" FOR EACH

Yes No

a) Promoting learning opportunities to employees

b) Directly providing learning or training opportunities to

c) $\quad$ Formployees with you

\begin{tabular}{|ll|c|c|l|}
\hline( & ) & 1 & 2 & \\
\hline( & ) & 1 & 2 & \\
\hline( & ) & 1 & 2 & \\
\hline
\end{tabular}

\section{ASK ALL}

I would now like to ask you about a number of initiatives connected with learning and training

30) Which of the following initiatives have you heard of...?

READ OUT. CODE ALL MENTIONED

\begin{tabular}{|l|c|}
\hline $\begin{array}{l}\text { National Vocational Qualifications or NVQs / Scottish } \\
\text { Vocational Qualifications or SVQs }\end{array}$ & 1 \\
\hline National Record of Achievement or NRA & 2 \\
\hline Learning Partnerships & 3 \\
\hline New Deal & 4 \\
\hline New Deal for Young People & 5 \\
\hline New Deal for Long Term Unemployed People & 6 \\
\hline Modern Apprenticeships & 7 \\
\hline National Traineeships & 8 \\
\hline Youth Training & 9 \\
\hline Other Government supported training for young people & 0 \\
\hline Time off for Study or Training & 1 \\
\hline & \\
\hline None of the above & $\mathrm{V}$ \\
\hline Don't know & $\mathrm{X}$ \\
\hline
\end{tabular}




\section{ASK ALL WHO HAVE HEARD OF ANY OF THE RELEVANT INITIATIVES}

(IF NONE, GO TO Q38)

31a) Which of these, to your knowledge, has your company been involved with at some time in the last twelve months?

READ OUT THOSE KNOWN AT Q30. CODE ALL MENTIONED

\begin{tabular}{|l|l|}
\hline National Record of Achievement or NRA & 1 \\
\hline Learning Partnerships & 2 \\
\hline
\end{tabular}

\section{ASK ALL WHO HAVE HEARD OF ANY OF THE RELEVANT INITIATIVES} (IF NONE, GO TO Q38)

31b) Have any of your employees been on any of the following initiatives in the last twelve months?

READ OUT THOSE KNOWN AT Q30. CODE ALL MENTIONED

\begin{tabular}{|l|c|}
\hline National Vocational Qualifications or NVQs / Scottish & 1 \\
\hline Vocational Qualifications or SVQs & ) \\
\hline New Deal - subsidised recruit & 3 \\
\hline New Deal - unsubsidised recruit & 4 \\
\hline Modern Apprenticeships & 5 \\
\hline National Traineeships & 6 \\
\hline Youth Training & 7 \\
\hline Other Government supported training for young people & 8 \\
\hline Time off for Study or Training & $\mathrm{V}$ \\
\hline None of the above & $\mathrm{X}$ \\
\hline Don't know & \\
\hline
\end{tabular}

ASK ALL AWARE OF NVQs I SVQs AT Q30 (IF NOT AWARE, GO TO Q38)

32) Are NVQs or SVQs currently offered to any employees at this location?

\begin{tabular}{|l|l|l|}
\multicolumn{1}{c}{(} & \\
\hline Yes & 1 & GO TO Q34 \\
\hline No & 2 & ASK Q33 \\
\hline
\end{tabular}

\section{IF YES}

33) How many of the employees here are NVQs or SVQs on offer to? PROBE FOR EXACT NUMBER

\begin{tabular}{|l|l|l|}
\hline $0-1000$ & \multicolumn{1}{|c|}{$(\quad)$} \\
\hline Don't know & $X$ & \\
\hline
\end{tabular}

PROMPT WITH RANGES AS NECESSARY

\begin{tabular}{|l|l|l|}
\hline None & $(2)$ \\
\hline $1-2$ & 2 & \\
\hline $3-4$ & 2 & \\
\hline $5-6$ & 3 & \\
\hline $7-8$ & 4 & \\
\hline $9-10$ & 5 & \\
\hline $11-19$ & 6 & \\
\hline
\end{tabular}




\begin{tabular}{|l|l|l|}
\hline $20-49$ & 8 & \\
\hline $50-99$ & 9 & \\
\hline $100-199$ & 0 & \\
\hline 200 or more & 1 & \\
\hline
\end{tabular}

\section{ASK ALL CURRENTLY OFFERING NVQs I SVQS AT Q32}

How satisfied are you with the NVQs and SVQs on offer?

READ OUT

\begin{tabular}{|c|c|c|}
\hline & & \\
\hline Very satisfied & 1 & \multirow{2}{*}{ ASK Q35 } \\
\hline Fairly satisfied & 2 & \\
\hline Not very satisfied & 3 & \multirow{2}{*}{ Go To Q36 } \\
\hline Not at all satisfied & 4 & \\
\hline
\end{tabular}

ASK Q35 IF VERY I FAIRLY SATISFIED AT Q34 (OTHERS GO TO Q36)

35) Why do you say that?

DO NOT READ OUT. CODE ALL MENTIONED

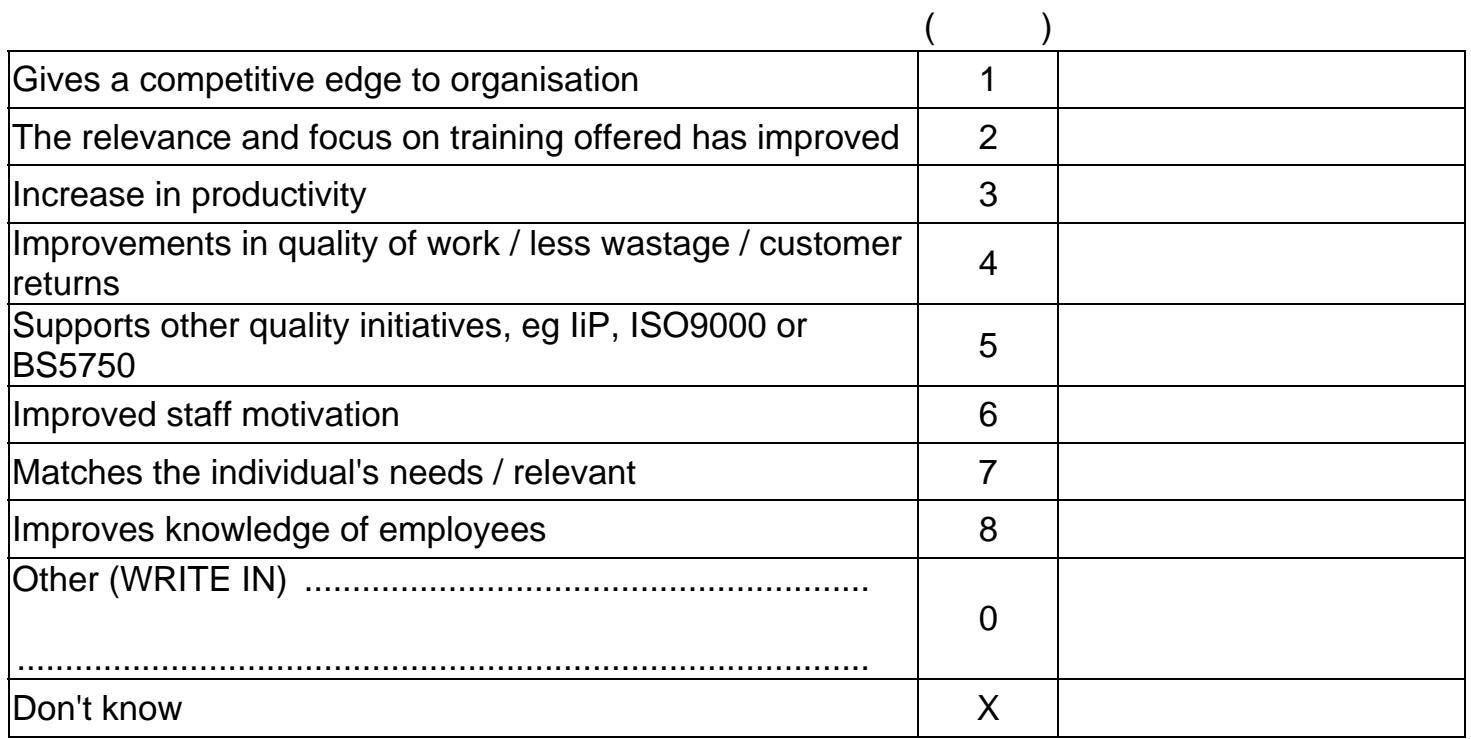

NOW GO TO Q37

ASK Q36 IF NOT VERYINOT AT ALL SATISFIED AT Q34 (OTHERS GO TO Q37)

36) Why do you say that?

DO NOT READ OUT. CODE ALL MENTIONED

\begin{tabular}{|l|l|l|}
\multicolumn{1}{l}{$\left(\begin{array}{l}\text { NVQs / SVQs do not cover all the skills the company } \\
\text { needs }\end{array}\right.$} & 1 & \\
\hline NVQs / SVQs cover skills the company does not need & 2 & \\
\hline NVQs / SVQs have proved too costly & 3 & \\
\hline $\begin{array}{l}\text { NVQs / SVQs have proved too bureaucratic / too much } \\
\text { red tape }\end{array}$ & 4 & \\
\hline NVQs / SVQs do not meet the company's business needs & 5 & \\
\hline Other WRITE IN ............................................................. & 0 & \\
\hline
\end{tabular}


ASK ALL CURRENTLY OFFERING NVQS I SVQS AT Q32

37) In your opinion, is the quality of assessment of NVQS and SVQs ...??

READ OUT. CODE ONE ONLY

\begin{tabular}{|c|c|c|}
\hline & & \\
\hline Very good & 1 & \\
\hline Fairly good & 2 & \\
\hline Neither good nor poor & 3 & \\
\hline Fairly poor & 4 & \\
\hline Very poor & 5 & \\
\hline Don't know & $x$ & \\
\hline
\end{tabular}

ASK ALL

38) Is this establishment formally recognised as an Investor in People?

\begin{tabular}{|l|l|l|}
\multicolumn{2}{|c|}{(} & \multicolumn{1}{|c|}{} \\
\hline Yes & 1 & \\
\hline No & 2 & \\
\hline Don't know & $X$ & \\
\hline
\end{tabular}

39) Is this establishment part of a larger organisation or is it the only establishment that the organisation has?

\begin{tabular}{|l|l|l|}
\hline Part of a larger organisation & 1 & \\
\hline Only establishment & 2 & \\
\hline
\end{tabular}




\section{ASK ALL WHO PROVIDE ANY TRAINING (YES AT Q12 OR YES AT Q25) \\ OTHERS TO FILTER ABOVE Q41}

40) You mentioned earlier that you have provided training to employees at this location in the last twelve months. I would like to send you a very short questionnaire for you to fill out in your own time, about the costs of providing training. Some of the questions on this questionnaire are quite detailed, so you may need to consult colleagues, such as those in your accounts department, or the heads of other departments in your organisation. For this reason, we would prefer to send you a written copy, rather than go through it all on the phone right now. We would then like to phone you back in a few days time to take down your answers. If you are unable to give exact answers to any of the questions, we would be happy to record your best estimates.

We are interested in finding out how many people at your establishment are involved in giving or receiving training, and how much money is spent doing so. Please feel free to ask the opinion of your colleagues if you are not able to answer the questions yourself.

\section{IF NECESSARY:}

Please do not fax, post or email the questionnaire back to us at IFF, as we would rather take down your answers over the phone. This will enable us to iron out any problems you may have with the questions.

The questionnaire is only a couple of pages long; it should only take about another five minutes to go through it on the phone.

Can I just check that it is OK for us to send you this questionnaire?

\begin{tabular}{|l|l|l|}
\multicolumn{2}{c}{$(\quad)$} \\
\hline Yes & 1 & \\
\hline No & 2 & Go to filter above Q41 \\
\hline
\end{tabular}

IF YES AT Q40

40a) Can I take down your fax number?

\begin{tabular}{|l|l|l|}
\multicolumn{1}{l|}{$\left(\begin{array}{l}\text { ) } \\
\hline \text { Record fax number }\end{array}\right.$} & 1 & \\
\hline $\begin{array}{l}\text { Respondent prefers other method of } \\
\text { receiving questionnaire }\end{array}$ & 2 & \\
\hline
\end{tabular}

IF RESPONDENT PREFERS OTHER METHOD. OTHERS GO TO Q40b

40b) How would you prefer us to send the questionnaire?

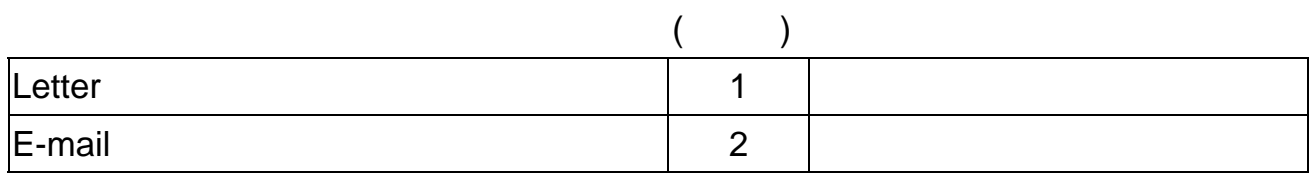

IF BY LETTER

40C) Can I take your address?

INTERVIEWER: CHECK ADDRESS AND INFORM SUPERVISOR THAT LETTER NEEDS TO BE SENT. NOW GO TO Q40e

IF BY E-MAIL

40d) Can I take down your e-mail address? 
INTERVIEWER: CHECK ADDRESS AND INFORM SUPERVISOR THAT EMAIL NEEDS TO BE SENT. NOW GO TO Q40e

40e) And can I take your name?

40f) Can I confirm your company name?

Thank you very much. We will fax / post / email you this questionnaire later today, and call you back in a few days time to collect your answers.

INTERVIEWER: Record any further useful information here (eg. When respondent would prefer to be called, etc)

ASK ALL WHO EMPLOY 16-17 YEAR OLDS AT Q2 (OTHERS THANK AND CLOSE)

41) Finally, you mentioned earlier that you currently employ 16-17 year olds at this location. The DfEE may want to carry out a further survey about the recruitment of young people. Would it be OK if we passed details of your company onto the DfEE for this purpose?

\begin{tabular}{|c|c|c|}
\hline & & \\
\hline Yes & 1 & \\
\hline No & 2 & $\begin{array}{l}\text { REASSURE RESPONDENT } \\
\text { THAT WE WILL NOT DO SO }\end{array}$ \\
\hline
\end{tabular}

THANK RESPONDENT AND CLOSE INTERVIEW

I declare that this survey has been carried out under IFF instructions and within the rules of the MRS Code of Conduct.

Date: 


\section{Cost of Training Questionnaire}

\section{Off-the-job training}

When answering the questions, please only consider employees who are normally based at your location. If you cannot give exact answers at any question, please give your best estimate.

This section of the questionnaire covers the costs of providing off-the-job training for employees. By off-the-job training, we mean all training given away from the immediate work position. It can be given at your premises or elsewhere.

If you have not provided any off-the-job training in the last twelve months, please go straight to the section on on-the-job training on the next page.

\section{Training courses}

1. Over the past twelve months, how many employees participated in an education or training course, provided either externally or internally? employees

If none, please skip to Q15. Otherwise, please answer Q2 onwards

2. How many days on average did each of these people spend on an education or training course over the past twelve months? days

3. What is the average basic annual salary of an employee who has been on any of these courses over the past twelve months? $£$

4. And what was the cost of fees to external providers of training courses for your employees over the past twelve months? Please include the cost of fees to any external providers who ran courses on your premises. $£$

\section{Training centres}

5 , Do you have a training centre at your location?

Yes please answer Q6
No please skip to Q7

If you have a training centre

6. How much did your training centre cost to run over the past twelve months? Please split the cost into:

a) Total basic annual salaries of any full time or part time training centre staff $£$

b) Other costs, including the cost of all equipment and materials used and the cost of rent paid for the space the training centre occupies.

$£$

Everybody please answer

7. How much did you spend on using off-site training centres located elsewhere within your company over the past twelve months? $£$

Did not use off-site training centre

Training staff and equipment Everybody please answer

8. How many people do you have at your establishment who are directly involved in providing, administering or making policy decisions about training? (Please exclude any staff directly associated with your training centre, if you have one) employees

If none, please skip to Q11. Otherwise, please answer Q9

9. On average, what percentage of their time do these staff spend on training matters? $\%$

10. And what is the average basic annual salary of these staff?

$£$

Everybody please answer

11. Apart from any training centre costs, what was the cost of any equipment and materials used for training employees over the past twelve months?

$£$

12. How much was spent on travel and subsistence payments and travelling time payments made to participants and trainers who spent time on courses over the past twelve months?€ 
Training organisations

13. What was the cost, if any, of subscriptions to ITBs, NTOs / ITOs or TECs / LECs involved in the provision of training over the past twelve months?

E

14. And how much did you receive in grants or subsidies over the past twelve months from ITBs, NTOs / ITOs, TECs / LECs or other government related sources to support the cost of training?

$£$

\section{Other off-the-job training}

Not all off-the-job training is course-based. The following few questions relate to off-thejob training that you may have provided that did not involve employees going on courses.

15. How many employees participated in seminars, workshops, or open or distance learning where the main purpose was training, over the past twelve months? employees

16. How many days on average did each of these spend away from their usual work position whilst engaged in any of these activities?

$$
\text { days }
$$

17. What is the average basic annual salary of an employee who has taken part in any of these activities over the last twelve months? $£$

18. And what was the total cost of fees to external providers of providing this type of off-the-job training over the past twelve months?

$£$

\section{On-the-job training}

This section of the questionnaire is concerned with on-the-job training. Please consider all training given at the desk or place where the person receiving training usually works.

Could you now focus on a typical month, preferably the last calendar month, but if not a recent more typical month of your choice.

19. How many employees do you estimate receive on-the-job training during a typical month? employees

If you do not give any on-the-job training, you do not need to answer the rest of the questionnaire.

20. Roughly how many working hours on average do you think each of these employees spends on on-the-job training during a typical month? Please think of the actual time spent in instruction or practical experience, excluding any periods of normal work. working hours

21. What is the average basic annual salary of your employees who receive on-the-job training in a typical month? £

22. How many employees do you estimate will give on-the-job training during a typical month? employees

23. Roughly how many working hours on average do you think each of these people spend giving on-the-job training during a typical month? working hours

24. What is the average basic annual salary of your employees who give on-the-job training in a typical month?

$£$

We will be calling you in the next couple of days to collect your answers. Many thanks for taking the time to help with this research. 